\title{
Combinatorial Epigenetics Impact of Polyphenols and Phytochemicals in Cancer Prevention and Therapy
}

\author{
Itika Arora ${ }^{1}$, Manvi Sharma ${ }^{1}$ and Trygve O. Tollefsbol ${ }^{1,2,3,4,5, *(\mathbb{C})}$ \\ 1 Department of Biology, University of Alabama at Birmingham, 1300 University Boulevard, Birmingham, AL \\ 35294, USA; itiarora@uab.edu (I.A.); manvi@uab.edu (M.S.) \\ 2 Comprehensive Center for Healthy Aging, University of Alabama Birmingham, 1530 3rd Avenue South, \\ Birmingham, AL 35294, USA \\ 3 Comprehensive Cancer Center, University of Alabama Birmingham, 1802 6th Avenue South, Birmingham, \\ AL 35294, USA \\ 4 Nutrition Obesity Research Center, University of Alabama Birmingham, 1675 University Boulevard, \\ Birmingham, AL 35294, USA \\ 5 Comprehensive Diabetes Center, University of Alabama Birmingham, 1825 University Boulevard, \\ Birmingham, AL 35294, USA \\ * Correspondence: trygve@uab.edu; Tel.: +1-205-934-4573; Fax: +1-205-975-6097
}

Received: 27 August 2019; Accepted: 11 September 2019; Published: 14 September 2019

\begin{abstract}
Polyphenols are potent micronutrients that can be found in large quantities in various food sources and spices. These compounds, also known as phenolics due to their phenolic structure, play a vital nutrient-based role in the prevention of various diseases such as diabetes, cardiovascular diseases, neurodegenerative diseases, liver disease, and cancers. However, the function of polyphenols in disease prevention and therapy depends on their dietary consumption and biological properties. According to American Cancer Society statistics, there will be an expected rise of 23.6 million new cancer cases by 2030. Due to the severity of the increased risk, it is important to evaluate various preventive measures associated with cancer. Relatively recently, numerous studies have indicated that various dietary polyphenols and phytochemicals possess properties of modifying epigenetic mechanisms that modulate gene expression resulting in regulation of cancer. These polyphenols and phytochemicals, when administrated in a dose-dependent and combinatorial-based manner, can have an enhanced effect on epigenetic changes, which play a crucial role in cancer prevention and therapy. Hence, this review will focus on the mechanisms of combined polyphenols and phytochemicals that can impact various epigenetic modifications such as DNA methylation and histone modifications as well as regulation of non-coding miRNAs expression for treatment and prevention of various types of cancer.
\end{abstract}

Keywords: epigenetics; cancer; polyphenols; DNA methylation; histone modifications; microRNA

\section{Introduction}

Cancer is the second leading cause of death in the United States [1]. Globally, 9.6 million deaths occurred in the year 2018 compared to 7.6 million cancer-associated deaths in 2008. Collectively, cancer is comprised of a heterogeneous group of disorders which involves uncontrolled proliferation of previously healthy cells [2]. Even though there are over 100 different types of cancers, the primary contributors to the increased mortality rates are cancer of the breast, lung, prostate, colon and rectum (a.k.a. colorectal cancer) [3-5]. It is, therefore, imperative to evaluate the factors leading to different types of cancers, their prevention, and therapeutic measures. The uncontrolled proliferation of cancer cells originates locally and may widely spread through metastasis. This process further results in loss of control of cell growth, eventually leading to the invasion of cancer cells to healthy tissues [6]. 
Factors such as alcohol consumption, exposure to harmful chemicals due to smoking, an unhealthy diet, and physical sedentariness result in higher rates of lifestyle-associated cancer risks (cancer-transition) in part by inducing mutations in DNA. Genetic changes and epigenetic aberrations play a critical role in the progression of the disease and each of these alterations is known to be an essential hallmark for different types of cancer [7-10]. Traditionally, cancer research was primarily focused on genetic changes, mainly elucidating the overexpression/mutation of oncogenes and inactivation of tumor suppressor genes (TSGs). Each of these changes reinforces major cancer pathways such as the RTK/RAS pathway, PI3K pathway, Wnt pathway, Myc pathway, p53 pathway, Notch Signaling pathway, Nrf2 pathway, and cell cycle pathways [11-16]. Since the 1990s, cancer research has also centered around understanding heritable changes which regulate various epigenetic alterations. Therefore, it is crucial to understand the etiology behind epigenetics mechanisms, which eventually lead to carcinogenesis [17]. Epigenetics is the study of changes in the phenotypes that do not arise from alterations in the DNA sequence. The various epigenetic mechanisms include DNA methylation, histone tail modifications, non-coding RNA functions, regulation of polycomb assembly proteins, and cofactor modifiers. DNA methylation and histone modifications are the primary contributors to cancer epigenetics machinery that eventually may cause alterations in gene expression but no alteration in the DNA sequence [18-22]. Unlike genetic changes such as mutations and deletions, which can be difficult to reverse [23,24], epigenetics aberrations are often reversible. Epigenetically altered genes can be potentially corrected, by reversing the alteration in DNA methylation found in CpG dinucleotides, for example, thereby causing transcriptional activation of histone complexes by acetylation and methylation [25]. Epigenetic modifications are also known to be a dynamic hallmark of cancer due to their massive impact on cell proliferation and differentiation.

Various studies have reported strong evidence that natural compounds can potentially regulate gene expression by targeting different foundations/components of the epigenetic machinery [26]. With the continuous advancement of the lifestyle changes, it is necessary to extract new molecules, which can be potentially used for disease prevention and to find new drugs which may be crucial for cancer patient survival. The natural compounds are extracted in part from vegetal [27], microbial [28], and marine species [29] (Figure 1). Each of these can widely be used as a major source of activities against cancer and other diseases such as diabetes [30], cardiovascular diseases [31], liver diseases [32], asthma [33], neurodegenerative diseases [34], osteoporosis [35], anemia [36], bulimia [37], influenza/ pneumonia [38], renal and thyroid disorders [39,40], nephritis [41], periodontal (gum) disease [42], hypertension [43] and skin disorders [44] (Figure 1).

Amongst various natural compounds, polyphenols have predominantly evolved as a large group of compounds by providing resistance and immunity against ultraviolet exposure, signal transduction and host defense against pathogens [45]. Although polyphenols are primarily involved with numerous mechanisms, through interactions with various cellular components such as carbohydrates, proteins and enzymes for the regulation of gene expression, they also exhibit active involvement in cancer pathways, in particular, signaling pathways $[46,47]$. Plant-based polyphenols are well-known to modulate cancer pathways by inhibiting cancer cell proliferation, which can cause an overall decrease in tumor mass, thus allowing tumor regression.

In spite of large preventive measures, plant-based dietary polyphenols also exhibit a significant role in protecting the healthy cells from adverse effects of chemotherapy by enhancing the cytotoxic activity of chemotherapeutic agents in cancerous cells [48].

A plethora of studies have described the anticancer mechanisms of polyphenols for individual compounds [49]. Despite being potent anti-cancer agents, many polyphenols have poor bioavailability thereby impeding there in vivo effects, mainly when used individually [50]. Their scope of efficacy can be increased by combining them with other different polyphenols and phytochemicals for potential synergistic effects. Here, we will focus on the combinatorial effects of various polyphenols, phytochemicals, and anti-cancer drugs on the epigenetics machinery by providing insights into their specific epigenetics targets associated with cancer prevention and therapy. 


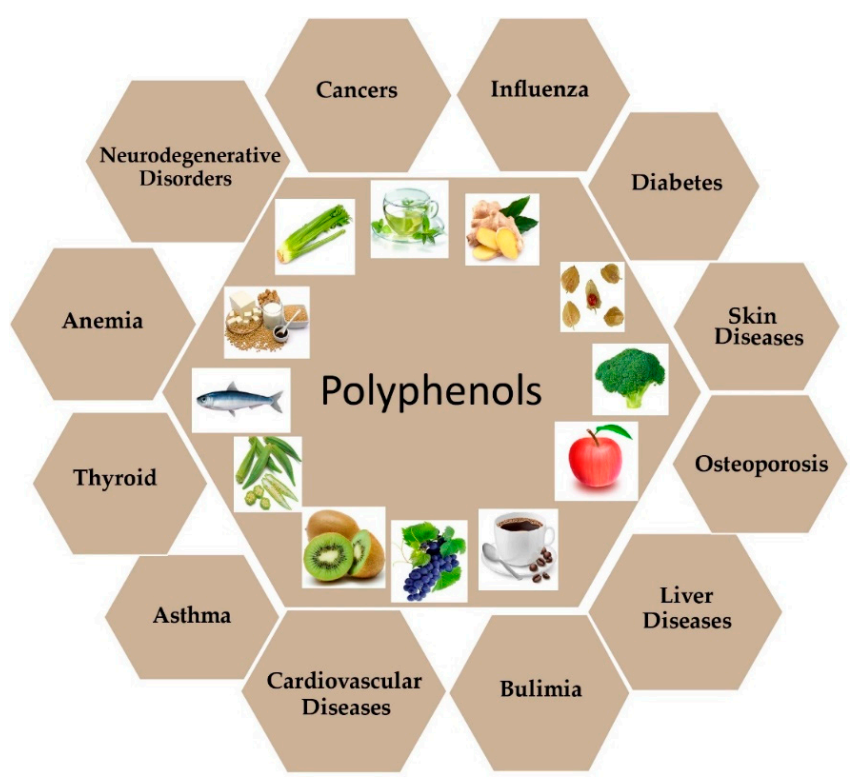

Figure 1. Health benefits effect of dietary polyphenols. Polyphenols are largely found in fruits, vegetables, spices, and beverages. Most of these compounds are involved in protection against the development of chronic diseases such as cardiovascular diseases (CVDs), neurodegenerative diseases, cancer, diabetes, osteoporosis, and liver diseases.

\section{Dietary-Based Polyphenols: Role in Cancer Prevention and Therapy}

Many studies have demonstrated the use of plant or animal-based natural compounds for prevention and treatment of multiple diseases such as asthma, cardiovascular diseases, pathogens protection, diabetes, neurodegenerative diseases and cancer [51]. More than 8000 polyphenolic compounds are from plant species [52]. Multiple studies have shown that some plant-based polyphenols possess anti-cancerous properties such as inhibition of cell proliferation, tumor growth, angiogenesis, metastasis, inflammation, and apoptosis [47,50]. These polyphenols can also be used as active compounds to develop novel chemopreventive agents, which can be highly effective while conferring little if any toxicity [47].

Polyphenols can be broadly classified into three main categories; flavonoids, stilbenoids, and phenolic acids [53] (Figure 2).

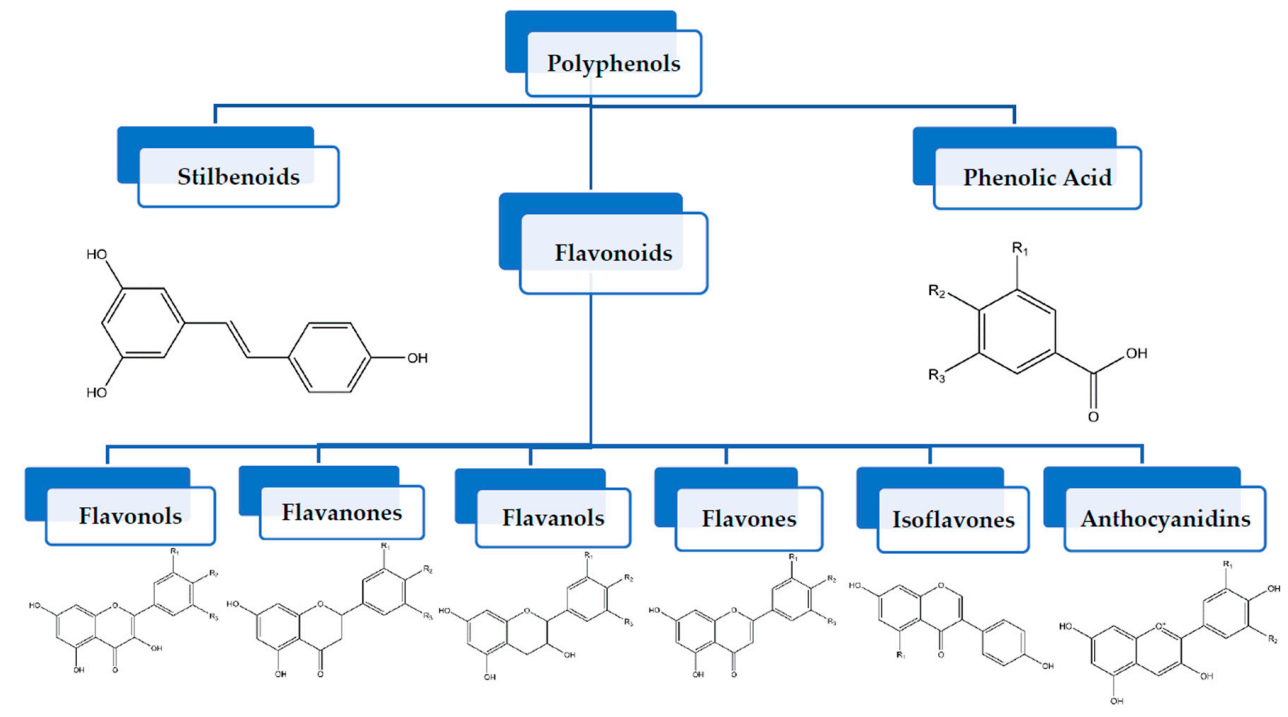

Figure 2. Different classification of polyphenols and their chemical structures. Flavonoids are subdivided into flavonols, flavanones, flavanols, flavones, isoflavones, and anthocyanidins. 
Among these, flavonoids are the largest group that are comprised of approximately 5000 polyphenols [54]. These classifications differ from each other based on the number of phenolic rings and their structural elements. Flavonoids account for about $60 \%$ of polyphenols which include two or more aromatic rings, linked by a carbon bridge containing three carbon atoms and the aromatic rings which possess one or more phenolic hydroxyl groups [55]. Flavonoids are subdivided into different subclasses: flavones, isoflavones, flavonols, flavanones, flavanols and anthocyanidins. Flavonoids possess various antioxidant and anti-inflammatory properties [56]. Among these, flavanols are the most abundant and are found in different food sources. For instance, quercetin, curcumin (CUR), and epigallocatechin-3-gallate (EGCG) are bioactive flavonoid compounds found in black tea, turmeric, and green tea [57-59]. The flavanols are further categorized into monomers (such as catechins found in red wine and chocolate) and polymers (such as proanthocyanidins and theaflavins) $[47,60]$. Unlike flavanols, flavones are less abundant in fruits and vegetables but found in parsley and celery to a greater extent [61]. Isoflavones, also known as phytoestrogens (due to their structural similarity to estrogens), are found in leguminous plants [62]. Table 1 provides a comprehensive list of the chemical structures and molecular formulas of the key polyphenols possessing anti-cancer properties.

Table 1. Classification of polyphenols, chemical structure, molecular formula and their dietary source availability.

\begin{tabular}{|c|c|c|c|c|}
\hline Polyphenols & Dietary Source & ${ }^{*}$ Chemical Structure & ${ }^{* *}$ Molecular Formula & References \\
\hline Apigenin & $\begin{array}{l}\text { Grapefruit, parsley, onion, } \\
\text { orange, tea and wheat } \\
\text { sprouts }\end{array}$ & & $\mathrm{C}_{15} \mathrm{H}_{10} \mathrm{O}_{5}$ & [63] \\
\hline Anacardic Acid & Cashew nuts & & $\mathrm{C}_{22} \mathrm{H}_{36} \mathrm{O}_{3}$ & [64] \\
\hline Biochanin & $\begin{array}{l}\text { Red clove, chickpea, clover } \\
\text { sprout and kidney beans }\end{array}$ & & $\mathrm{C}_{16} \mathrm{H}_{12} \mathrm{O}_{5}$ & [65-67] \\
\hline Butein & $\begin{array}{l}\text { Rhus verniciflua, Caesalpinia } \\
\text { sappan and Carthamus } \\
\text { tinc-torius }\end{array}$ & & $\mathrm{C}_{15} \mathrm{H}_{12} \mathrm{O}_{5}$ & {$[68,69]$} \\
\hline Catechin & $\begin{array}{l}\text { Green tea, apples, } \\
\text { blackberries, dark chocolate } \\
\text { and red wine }\end{array}$ & & $\mathrm{C}_{15} \mathrm{H}_{14} \mathrm{O}_{6}$ & [70] \\
\hline Cyanidin & $\begin{array}{l}\text { Acai berry, bilberry, } \\
\text { blackberry, cranberry and } \\
\text { raspberry }\end{array}$ & & $\mathrm{C}_{15} \mathrm{H}_{11} \mathrm{O}_{6}{ }^{+}$ & [71] \\
\hline Curcumin (CUR) & Turmeric & & $\mathrm{IC}_{21} \mathrm{H}_{20} \mathrm{O}_{6}$ or $\mathrm{C}_{21} \mathrm{H}_{20} \mathrm{O}_{6}$ & [72] \\
\hline Caffeic Acid & Coffee and olive oil & & $\mathrm{C}_{9} \mathrm{H}_{8} \mathrm{O}_{4}$ & [73] \\
\hline Cholorogenic Acid & Pomegranate and berries & & $\mathrm{C}_{16} \mathrm{H}_{18} \mathrm{O}_{9}$ & [74] \\
\hline
\end{tabular}


Table 1. Cont.

\begin{tabular}{|c|c|c|c|c|}
\hline Polyphenols & Dietary Source & ${ }^{*}$ Chemical Structure & ${ }^{* *}$ Molecular Formula & References \\
\hline Capsaicin & Chili peppers & & $\mathrm{C}_{18} \mathrm{H}_{27} \mathrm{NO}_{3}$ & [75] \\
\hline Daidzein & Soybeans and tofu & & $\mathrm{C}_{15} \mathrm{H}_{10} \mathrm{O}_{4}$ & {$[76,77]$} \\
\hline Delphinidin & Cereal grains & & $\mathrm{C}_{15} \mathrm{H}_{11} \mathrm{CIO}_{7}$ & [78] \\
\hline Diosmetin & Vetch & & $\mathrm{C}_{16} \mathrm{H}_{12} \mathrm{O}_{6}$ & [79] \\
\hline Ellagic Acid & $\begin{array}{l}\text { Blackberries, raspberries and } \\
\text { pomegranate }\end{array}$ & & $\mathrm{C}_{14} \mathrm{H}_{6} \mathrm{O}_{8}$ & [80] \\
\hline Epicatechin & $\begin{array}{l}\text { Milk, chocolates, and } \\
\text { commercial reduced fat }\end{array}$ & & $\mathrm{C}_{15} \mathrm{H}_{14} \mathrm{O}_{6}$ & [81] \\
\hline $\begin{array}{l}\text { Epigallocatechin-3-gallate } \\
\text { (EGCG) }\end{array}$ & Green tea & & $\mathrm{C}_{22} \mathrm{H}_{18} \mathrm{O}_{11}$ & [70] \\
\hline Gallic Acid & $\begin{array}{l}\text { Pomegranate, nuts and } \\
\text { green tea }\end{array}$ & & $\mathrm{C}_{7} \mathrm{H}_{6} \mathrm{O}_{5}$ & [82] \\
\hline Genistein & $\begin{array}{l}\text { Fats, oils, beef, red clover, } \\
\text { soybeans, and fava beans }\end{array}$ & & $\mathrm{C}_{15} \mathrm{H}_{10} \mathrm{O}_{5}$ & {$[83,84]$} \\
\hline Gnetol & $\begin{array}{l}\text { Gnetum ula, gnetum gnemon, } \\
\text { trees, shrubs and lianas }\end{array}$ & & $\mathrm{C}_{14} \mathrm{H}_{12} \mathrm{O}_{4}$ & [85] \\
\hline Hesperidin & $\begin{array}{l}\text { Bitter orange, petit grains, } \\
\text { orange, lime and lemon }\end{array}$ & & $\mathrm{C}_{28} \mathrm{H}_{34} \mathrm{O}_{15}$ & [86] \\
\hline
\end{tabular}


Table 1. Cont.

\begin{tabular}{|c|c|c|c|c|}
\hline Polyphenols & Dietary Source & ${ }^{*}$ Chemical Structure & ** Molecular Formula & References \\
\hline Isoliquiritigenin & Rose petals & & $\mathrm{C}_{15} \mathrm{H}_{12} \mathrm{O}_{4}$ & [87] \\
\hline Kaempferol & $\begin{array}{l}\text { Apples, grapes, tomatoes, } \\
\text { green tea, potatoes, onions } \\
\text { and broccoli }\end{array}$ & & $\mathrm{C}_{15} \mathrm{H}_{10} \mathrm{O}_{6}$ & [88] \\
\hline Licochalcone A & Cranberry & & $\mathrm{C}_{21} \mathrm{H}_{22} \mathrm{O}_{4}$ & [89] \\
\hline Luteolin & $\begin{array}{l}\text { Celery, broccoli, green } \\
\text { pepper, parsley, thyme, } \\
\text { dandelion, perilla and } \\
\text { chamomile tea }\end{array}$ & & $\mathrm{C}_{15} \mathrm{H}_{10} \mathrm{O}_{6}$ & {$[90,91]$} \\
\hline Macluraxanthone & $\begin{array}{l}\text { Maclura tinctoria (Hedge } \\
\text { apple) and dyer's mulberry }\end{array}$ & & $\mathrm{C}_{23} \mathrm{H}_{22} \mathrm{O}_{6}$ & [92] \\
\hline Myricetin & $\begin{array}{l}\text { Vegetables, fruits, nuts, } \\
\text { berries, tea and red wine }\end{array}$ & & $\mathrm{C}_{15} \mathrm{H}_{10} \mathrm{O}_{8}$ & [93] \\
\hline Naringenin & Grapes & & $\mathrm{C}_{15} \mathrm{H}_{12} \mathrm{O}_{5}$ & [94] \\
\hline Oxyresveratrol & $\begin{array}{l}\text { Morus alba and artocarpus } \\
\text { lakoocha }\end{array}$ & & $\mathrm{C}_{14} \mathrm{H}_{12} \mathrm{O}_{4}$ & [95] \\
\hline Peonidin & $\begin{array}{l}\text { Cranberries, blueberries, } \\
\text { plums, cherries and sweet } \\
\text { potatoes }\end{array}$ & & $\mathrm{C}_{16} \mathrm{H}_{13} \mathrm{O}_{6}+$ & [96] \\
\hline Piceatannol & $\begin{array}{l}\text { Berries, grapes, rhubarb } \\
\text { (rheum), passion fruit } \\
\text { (passiflora) and white tea. }\end{array}$ & & $\mathrm{C}_{14} \mathrm{H}_{12} \mathrm{O}_{4}$ & [97] \\
\hline Pterostilbene & Blueberries and grapes & & $\mathrm{C}_{16} \mathrm{H}_{16} \mathrm{O}_{3}$ & [98] \\
\hline
\end{tabular}


Table 1. Cont.

\begin{tabular}{|c|c|c|c|c|}
\hline Polyphenols & Dietary Source & * Chemical Structure & ** Molecular Formula & References \\
\hline Quercetin & $\begin{array}{l}\text { Vegetables, fruits and } \\
\text { beverages, spices, soups and } \\
\text { fruit juices }\end{array}$ & & $\mathrm{C}_{15} \mathrm{H}_{10} \mathrm{O}_{7}$ & {$[99,100]$} \\
\hline Resveratrol & $\begin{array}{l}\text { Almonds, blueberries and } \\
\text { grapes }\end{array}$ & & $\mathrm{C}_{14} \mathrm{H}_{12} \mathrm{O}_{3}$ & [98] \\
\hline Rosemarinic Acid & Rosemary & & $\mathrm{C}_{18} \mathrm{H}_{16} \mathrm{O}_{8}$ & [101] \\
\hline Rutin & $\begin{array}{l}\text { Citrus fruits, apple, berries } \\
\text { and peaches }\end{array}$ & & $\mathrm{C}_{27} \mathrm{H}_{30} \mathrm{O}_{16}$ & {$[92,102,103]$} \\
\hline Scopoletin & $\begin{array}{l}\text { Vinegar, dandelion and } \\
\text { coffee }\end{array}$ & & $\mathrm{C}_{10} \mathrm{H}_{8} \mathrm{O}_{4}$ & [104] \\
\hline Silibinin & Milk and artichokes & & $\mathrm{C}_{25} \mathrm{H}_{22} \mathrm{O}_{10}$ & {$[105,106]$} \\
\hline Tangeretin & Citrus fruits & & $\mathrm{C}_{20} \mathrm{H}_{20} \mathrm{O}_{7}$ & [107] \\
\hline Taxifolin & Vinegar & & $\mathrm{C}_{15} \mathrm{H}_{12} \mathrm{O}_{7}$ & [108] \\
\hline Theaflavin & $\begin{array}{l}\text { Tea leaves, black tea and } \\
\text { oolong tea }\end{array}$ & & $\mathrm{C}_{29} \mathrm{H}_{24} \mathrm{O}_{12}$ & [109] \\
\hline Tricin & Rice bran and sugarcane & & $\mathrm{C}_{17} \mathrm{H}_{14} \mathrm{O}_{7}$ & [110] \\
\hline Xanthohumol & Hop plants & & $\mathrm{C}_{21} \mathrm{H}_{22} \mathrm{O}_{5}$ & [111] \\
\hline
\end{tabular}

${ }^{*}$ Chemical structures are drawn using ChemDraw software. ${ }^{* *}$ Molecular formulas obtained through PubChem compound database. 
Stilbenoids, another critical category of polyphenols, are a small group of compounds which contain polyhydroxystilbenes. These are found in lower quantities in our diet, thereby compromising their potential for significant health benefits. However, more massive amounts of stilbenoids can be provided from various strenuous extracts or as purified compounds. For instance, resveratrol (found in red wine, peanuts, grapes, and almonds) and pterostilbene (present in blueberries and grapes) are key stilbenoids that have anticarcinogenic properties and other health benefits [112]. Another primary classification of polyphenols, phenolic acids, account for $30 \%$ of polyphenols and consist of two main categories; hydroxybenzoic acid and hydroxycinnamic acid which are glycosylated derivatives of esters of quinic acid, shikimic acid, and tartaric acid. Hydroxybenzoic acid, is found in few consumable plants making it of lesser nutritional interest, although hydroxycinnamic acid is found in cinnamon, coffee, blueberries, kiwis, plums, apples, and cherries [113,114].

\section{Bioavailability of Polyphenols}

Bioavailability pertains to the process of nutrient digestion, absorption, and metabolism in biochemical pathways. After digestion and before absorption of polyphenols, they are hydrolyzed by intestinal enzymes that are present in the colon. During intake, polyphenols undergo various modifications and are further processed in the liver through methylation, sulfation, and glucuronidation [115]. It has been evident that polyphenols possess metabolic activities, which primarily depends on intrinsic activity, rate of metabolism, and their elimination. Polyphenol metabolic activity mainly occurs in the intestines and liver. Since most biologically active polyphenols are not very common in the diet, the bioavailability of polyphenols signifies a significant issue as they may reach the target organs in low concentrations [116]. Because of this many polyphenols portray a poor bioavailability as anti-cancer agents, thereby moderating in vivo effects.

One way to thwart this issue is with the help of nanotechnology, which plays a vital role in cancer prevention and treatment. Nanoparticle encapsulation of anticancer polyphenols can cause a several-fold increase to their oral bioavailability. For example, nanoformulations of curcumin and piperine combination led to a 9-fold expansion due to enhanced absorption thereby increasing efficacy and creating a dose advantage over free curcumin in different cancer cell lines [117]. Despite combating the low bioavailability of polyphenols, only a few combinations have been tried as nano-encapsulation as it can cause adverse side effects when administered in high doses [118-120]. Various studies have shown strong evidence of combinatorial effects of different polyphenols that increased chemoprotective and the anti-cancer properties at considerably lower concentrations [121]. This synergy of polyphenols in some cases is due to simultaneous impact on different cancer pathways as well as epigenetic modifications such as DNA methylation and histone modifications.

\section{Epigenetics Mechanisms and Cancer}

\subsection{DNA Methylation}

DNA methylation plays a crucial role in regulating growth and development of carcinogenesis by contributing to aberrations such as genomic instability, oncogenes activation and silencing of tumor suppressor genes (TSGs) which are mainly involved in cell proliferation, DNA repair and apoptosis [17,122-124]. The CPG positions are the areas of DNA where a cytosine nucleotide is followed by a guanine nucleotide in a $5^{\prime} \rightarrow 3^{\prime}$ direction. These occur primarily in genomic as CpG islands. CpG dinucleotides are unevenly distributed in the human genomes but are common in promoter regions of genes. The DNA methylation state is modulated by the DNA methyltransferase (DNMT) enzymes. DNMTs are actively involved in the displacement of the methyl group from S-adenosyl-L-methionine (SAM) and placing it onto the 5-position of certain cytosines in CpG dinucleotides [49]. In mammals, there are three major types of DNMTs: DNMT1, DNMT3a, and DNMT3b [125]. DNMT1 is a ubiquitous enzyme and is primarily responsible for the maintenance of DNA methylation patterns during cell 
division. The DNMT3a and DNMT3b enzymes actively participate in de novo methylation processes, which involve the addition of a methyl group to cytosine and is necessary for differentiation [126,127].

Studies have provided strong evidence supporting the association of both DNA hypomethylation and hypermethylation sequences during cancer progression and have emphasized the importance of DNA hypomethylation and hypermethylation in the regulation of cancer-related genes [128]. The hypermethylation of $\mathrm{CpGs}$ can occur in the $5^{\prime}$ region of the cancer-associated genes and lead to inactivation of a significant number of tumor-suppressor genes during tumorigenesis in cancers. Either a single gene or small subsets of genes can be hypermethylated in different types of cancer [129]. For instance, $p 16 I N K 4 a(C D K N 2 A)$ which acts as a cyclin-dependent kinase inhibitor essential for TSGs, can undergo hypermethylation in cancer. Hypermethylation of TSGs such as E-Cadherins and H-Cadherins can cause metastasis, leading to tumor cells proliferation [130]. In addition, the silencing of APC gene has also been reported in various cancers such as breast, lung, prostate, and colorectal cancer. APC acts as an antagonist of the Wnt Signaling pathway, which is efficiently involved with cell migration and adhesion. Other instances of gene silencing are found in breast cancer, such as the silencing of BRCA1, resulting in DNA repair double-stranded breaks and transcription [131]. Unlike DNA hypermethylation of individual genes, genomic DNA hypomethylation of different genes in tumor cells is a rare phenomenon. DNA hypomethylation can cause chromosomal abnormality and induce mutations, thereby leading to activation of some transposable elements that may result in modification of the genome at random sites [132]. As a result, mutagenesis and genomic instability occur, thus leading to tumor development. Hypomethylation of TTF-3 and MUC4 frequently occurs in ovarian cancer, prostate cancer and pancreatic cancer [133].

A large number of FDA-approved drugs such as paclitaxel, doxorubicin, cisplatin, vorinostat, decitabine, and azacitidine have shown a potential role in cancer therapy via targeting the DNMTs. Therefore, the DNA methylation process is an important area with respect to epigenetic mechanisms leading to different types of cancer [134]. Only a few FDA-approved drugs have shown promising results in cancer patients due to their slight specificity towards cancerous cells [135]. Therefore, to increase the response of anti-cancer drugs towards cancerous cells, cancer patients are subjected to increased doses, which may result in adverse side effects.

Nutritional polyphenols and phytochemicals have an enormous impact on DNA methylation by causing changes in DNMTs levels via the direct or indirect effect on DNMT activity in cancer prevention and therapy. For instance, genistein of soy forms a complex with DNMT reducing methylation activity and resulting in activation of tumor suppressor genes which can eventually lead to cancer prevention and therapy [136]. Resveratrol, primarily found in grapes, also acts as a DNMT inhibitor, which may facilitate cancer prevention and treatment [137]. Table 2 provides a comprehensive list of different polyphenols and their effects on the DNA methylation epigenetic machinery.

\subsection{Histone Modifications}

Histones are soluble proteins involved in wrapping DNA into a structural unit called nucleosomes. The nucleosome, approximately $\sim 146 \mathrm{bp}$, is positioned as beads at a regular distance [138]. Classically, a nucleosome is comprised of linker histones $\mathrm{H} 1$ and core histones: $\mathrm{H} 2 \mathrm{~A} / \mathrm{H} 2 \mathrm{~B}, \mathrm{H} 3$, and $\mathrm{H} 4$. Linker histones (H1) are also a primary component of nucleosomes [139]. The linker histone H1 binds to the outside of the nucleosome periphery and serves as a bridge between two adjacent nucleosomes. Core histones are more firmly bound to the DNA than H1 [140].

Histone modifications are also actively involved with tumor development and carcinogenesis [141] and most occur at the globular N-terminus domain which protrudes outwards from core histones $\mathrm{H} 3$ and $\mathrm{H} 4$. The $\mathrm{N}$-terminus domain is prone to various chemical changes at lysine, serine, and threonine [142]. Post-translational modifications (PTMs) are also a primary component of the epigenome assembly which contributes to histone modifications. PTMs often lead to charge-induced changes in the nucleosome, which causes a massive influence on the gene expression. Histones associated with PTMs also assist many 
biological processes through chromatin modifications and PTMs can impact gene expression by altering chromatin structures, which contribute significantly to tumor development and carcinogenesis [142].

Even though PTMs are reversible, they are not restricted to lysine acetylation, lysine-arginine methylation, serine-threonine phosphorylation, and lysine ubiquitination [143]. Various catalytic enzymes such as histone acetyltransferases (HATs), histone deacetylases (HDACs), histone methyltransferases (HMTs) and histone demethylases (HDMs) also contribute to histone modifications. These induced histone modifications can result in cancer initiation and progression by causing genome-wide alterations [144]. HAT enzymes are actively involved in histone acetylation, which is responsible for the regulation of various cellular processes such as transcription, gene silencing, apoptosis, DNA repair, and cell differentiation $[145,146]$. Unlike HATs, HDACs are a class of enzymes which catalyzes the opposite action of HATs by influencing various processes such as signal transduction, apoptosis, and cell growth [147]. Histone acetylation imbalance due to these catalytic processes can lead to tumor cell development and cancer progression. HMTs and HDMs also act as a stimulus for histone modifications. HMTs are involved in DNA methylation via chromatin-dependent transcriptional repression and activation [148]. Due to these catalytic processes, specific genes within DNA complexed with histone can either be activated or silenced [149]. Amongst various types of HMTs, G9a and EZH2 are critical histone methyltransferases, as they catalyze methylation of histone $\mathrm{H} 3$ at lysine 27 (H3-K27). The H3-K27 methylation and lysine 9 histone H3 methylation (H3-K9) facilitate the development of heterochromatin resulting in gene silencing and contribute to cancer progression [150].

Many dietary polyphenols have promise in modulating histone modifications in cancer prevention and therapy. For example, sulforaphane, in broccoli, kale and cauliflower, complexes with the HDACs active sites thereby impeding HDAC activity [151].

\subsection{Noncoding RNAs}

Besides DNA methylation and histone modifications, microRNAs (miRNAs) also significantly contribute to epigenetic regulation. miRNAs can perform RNA splicing-related catalytic functions and miRNAs significantly contribute to post-translational gene regulations. miRNAs are small single-stranded non-coding RNAs that are 20-22 nucleotides long and regulate gene expression via post-translational silencing of the target genes [152]. miRNAs control numerous biological processes, such as cell proliferation, apoptosis, and cell differentiation. Due to their significant role in cell physiology, expression level alterations are directly related to disease progression. A large number of studies has shown direct association between miRNAs alterations and cancer [152-155]. MicroRNA expression can be regulated by different mechanisms such as chromosomal abnormalities, single nucleotide polymorphisms (SNPs), mutations in the primary transcripts such as $m i R-15 a$ and miR-16-1 [156], altered activity of different transcription factors such as miR-17-92 cluster and changes in $m i R-34$ family due to activation of $p 53$. These mechanisms can be associated with different types of cancers such those of the bladder, lung and breast [156-158]. For instance, hypermethylation of $m i R-9-1$ in breast cancer occurs while $m i R-34 b$ and $m i R-34 c$ clusters are hypermethylated in colorectal cancer $[159,160]$. Deviant methylation of $m i R-9, m i R-34 b, m i R-34 c$ and $m i R-148 a$ are often associated with metastasis. Furthermore, methylation of $m i R-148 a, m i R-34 b / c$ and $m i R-9$ are commonly associated with malignant cells [161]. In addition to these aberrations, promoter methylation and histone acetylation can also regulate microRNA expression in different types of cancer [162]. Table 2 provides a comprehensive list of polyphenols which are known to regulate epigenetic modifications associated with different types of cancer. 
Table 2. Assessment of polyphenols and their associated epigenetics modifications and molecular mechanisms (in vivo and in vitro studies) in cancer.

\begin{tabular}{|c|c|c|c|c|c|c|c|}
\hline $\begin{array}{l}\text { Dietary } \\
\text { Compounds }\end{array}$ & $\begin{array}{l}\text { Epigenetic } \\
\text { Modifications }\end{array}$ & Gene Targets & $\begin{array}{l}\text { * Overall Role in Cancer } \\
\text { Progression }\end{array}$ & Dose & In Vitro Model & In Vivo Model & References \\
\hline Apigenin & $\begin{array}{l}\text { DNMT1 inhibitor } \\
\text { DNMT3a inhibitor } \\
\text { DNMT3b inhibitor } \\
\text { HDAC1 inhibitor } \\
\text { HDAC3 inhibitor }\end{array}$ & $\begin{array}{l}\text { NFE2L, NQO1, Nrf2, } \\
\text { GRP78, GADD153, p21, } \\
\text { waf1, and } h T E R T \\
p 53\end{array}$ & $\begin{array}{l}\downarrow \text { Viability } \\
\downarrow \text { GLI1 expression } \\
\text { Cell cycle arrest } \\
\uparrow \text { Apoptosis } \\
\uparrow \text { Caspase } 3 \text { Activity }\end{array}$ & $\begin{array}{l}20-30 \mu \mathrm{M} \\
40-160 \mu \mathrm{M} \\
20-50 \mu \mathrm{M} \\
20-100 \mu \mathrm{M} \\
20-40 \mu \mathrm{M}\end{array}$ & $\begin{array}{l}\text { Pancreatic cancer } \\
\text { Lung cancer (H460 cells) } \\
\text { Breast cancer (BT-474 cells) } \\
\text { Skin cancer (JB6 P+ cells) } \\
\text { Prostate cancer (PC-3, 22Rv1 cells) }\end{array}$ & Mouse & [163-170] \\
\hline Curcumin & $\begin{array}{l}\text { DNMT inhibitor } \\
\text { HAT inhibitor } \\
\text { HDAC1 inhibitor } \\
\text { Down-regulation of } \\
\text { histone methylation }\end{array}$ & $\begin{array}{l}\text { CDKN2B, NEUROG1, } \\
\text { NFE2L2, Nrf2, Neurog1 } \\
\text { RASSF1A, p16, SPARC, } \\
\text { SOCS1, SOCS3, p53, p21, } \\
\text { GAS5, HOTAIR, H19, } \\
\text { AF086415, AK095147, } \\
\text { RP1-17916.3, MUDENG, } \\
\text { AK056098, AK294004 }\end{array}$ & $\begin{array}{l}\downarrow \text { Proliferation } \\
\uparrow \text { Apoptosis } \\
\downarrow \text { ERK, MKK4, JNK activity } \\
\downarrow \text { Bcl-2 } \\
\downarrow \text { Akt expression } \\
\uparrow \text { p38 activation } \\
\downarrow \text { Cell viability } \\
\uparrow \text { Bax Activity }\end{array}$ & $\begin{array}{l}40 \mu \mathrm{M} \\
0-100 \mu \mathrm{M} \\
0-50 \mu \mathrm{M} \\
2.5-160 \mu \mathrm{M} \\
7.5-10 \mu \mathrm{M} \\
0-50 \mu \mathrm{M}\end{array}$ & $\begin{array}{l}\text { Breast cancer (MCF-7 cells) } \\
\text { Prostate cancer (LnCap cells) } \\
\text { Colorectal cancer (HCT116, HT29 and } \\
\text { RKO cell lines) } \\
\text { Gastric cancer (MiaPaCa-2, PANC-1 cells) } \\
\text { Breast cancer (MCF-7 cells) } \\
\text { Ovarian cancer (SKOV3 cells) }\end{array}$ & & [171-182] \\
\hline Daidzein & $\begin{array}{l}\text { DNMT inhibitor } \\
\text { HDAC inhibitor }\end{array}$ & $\begin{array}{l}\text { BRCA1, GSTP1, EPHB2, } \\
M M P-2, B R F 1, B R F 2, \\
R A R \beta\end{array}$ & $\begin{array}{l}\downarrow \text { Proliferation } \\
\uparrow \text { Apoptosis } \\
\downarrow \text { ERK, MKK4, JNK activity }\end{array}$ & $\begin{array}{l}200-600 \mu \mathrm{M} \\
20-100 \mu \mathrm{M} \\
3-50 \mu \mathrm{M} \\
12.8-100 \mu \mathrm{M}\end{array}$ & $\begin{array}{l}\text { Colorectal cancer } \\
\text { Breast cancer (MDA-MB-231 cells) } \\
\text { Liver cancer (SKHEP-1 cells) } \\
\text { Prostate cancer }\end{array}$ & & {$[62,183,184]$} \\
\hline Delphinidin & $\begin{array}{l}\text { DNMT inhibitor } \\
\text { HAT inhibitor } \\
\text { HDAC-3 inhibitor }\end{array}$ & $\begin{array}{l}p 21, \text { WAF1/Cip1, p53, } \\
p 27 / K I P 1\end{array}$ & $\begin{array}{l}\downarrow \text { Cell Proliferation } \\
\downarrow \text { Metastasis } \\
\text { Cell Cycle Arrest } \\
\text { Oxidative Stress }\end{array}$ & $\begin{array}{l}3-90 \mu \mathrm{M} \\
30-240 \mu \mathrm{M} \\
5-60 \mu \mathrm{M} \\
100 \mu \mathrm{M}\end{array}$ & $\begin{array}{l}\text { Prostate cancer (PC3 cells) } \\
\text { Colorectal cancer (HCT116 cells) } \\
\text { Lung cancer (NCI-H441 cells) } \\
\text { Prostate cancer (LNCaP cells) }\end{array}$ & Athymic nude mice & [185-188] \\
\hline Myricetin & $\begin{array}{l}\text { DNMT inhibitor } \\
\text { Increased SIRT1 activity }\end{array}$ & GSTP1, RAR $\beta$, HIN-1 & $\begin{array}{l}\uparrow \text { Apoptosis } \\
\text { Autophagy }\end{array}$ & $\begin{array}{l}20-40 \mu \mathrm{M} \\
5-25 \mu \mathrm{M} \\
100 \mu \mathrm{M}\end{array}$ & $\begin{array}{l}\text { Gastric cancer (GC HGC-27, SGC7901 cells) } \\
\text { Breast cancer } \\
\text { Colon cancer (HCT-15 cells) }\end{array}$ & & [189-191] \\
\hline Ellagic Acid & $\begin{array}{l}\text { DNMT1 inhibitor } \\
\text { DNMT3b inhibitor } \\
\text { HDAC inhibitor }\end{array}$ & $\begin{array}{l}\text { p16INK4a, RASSF1A, } \\
\text { GSTP1, HIN1, VEGF, } \\
\text { MMP-2, p53 }\end{array}$ & $\begin{array}{l}\uparrow \text { Apoptosis } \\
\text { Cell proliferation } \\
\text { Cell migration } \\
\uparrow \text { Caspase 3 Activity } \\
\uparrow \text { Caspase 9 Activity }\end{array}$ & $\begin{array}{l}50-200 \mu \mathrm{M} \\
10-100 \mu \mathrm{M}\end{array}$ & $\begin{array}{l}\text { Colorectal cancer } \\
\text { Prostate cancer (PC-3 cells) } \\
\text { Breast cancer (MCF-7 cells) }\end{array}$ & & [192-195] \\
\hline EGCG & $\begin{array}{l}\text { DNMT inhibitor } \\
\text { HAT inhibitor } \\
\text { Down-regulation of } \\
\text { histone methylation } \\
\text { Effect on histone } \\
\text { ubiquitination } \\
\text { Upregulation of histone } \\
\text { phosphorylation }\end{array}$ & $\begin{array}{l}\text { p16INK4a; RAR } \beta ; \text { MGMT; } \\
\text { hMLH1; GSTP1; WIF-1; } \\
\text { RECK, Cip1/p21 } \\
\text { AT102202, p53, p21 }\end{array}$ & $\begin{array}{l}\downarrow \text { Invasiveness } \\
\downarrow \text { Proliferation } \\
\uparrow \text { Apoptosis } \\
\uparrow \text { Caspase 3 Activity } \\
\uparrow \text { Caspase 8 Activity } \\
\uparrow \text { Cytochrome c }\end{array}$ & $\begin{array}{l}1-40 \mu \mathrm{M} \\
1-50 \mu \mathrm{M} \\
5-20 \mu \mathrm{M} \\
20-100 \mu \mathrm{M} \\
1-50 \mu \mathrm{M} \\
0-20 \mu \mathrm{g} / \mathrm{mL}\end{array}$ & $\begin{array}{l}\text { Breast cancer (MCF-7 cells) } \\
\text { Colorectal cancer (HT-29 cells) } \\
\text { Lung cancer (CL1-5 cells) } \\
\text { Gastric cancer (MKN-1, MKN-28, MKN-45, } \\
\text { NUGC-3 and TMK-1) } \\
\text { Colorectal cancer } \\
\text { Skin cancer (A431 cells) }\end{array}$ & Xenograft mice & {$[47,196-208]$} \\
\hline
\end{tabular}


Table 2. Cont

\begin{tabular}{|c|c|c|c|c|c|c|c|}
\hline $\begin{array}{l}\text { Dietary } \\
\text { Compounds }\end{array}$ & $\begin{array}{l}\text { Epigenetic } \\
\text { Modifications }\end{array}$ & Gene Targets & $\begin{array}{l}\text { * Overall Role in Cancer } \\
\text { Progression }\end{array}$ & Dose & In Vitro Model & In Vivo Model & References \\
\hline Hesperidin & $\begin{array}{l}\text { DNMT inhibitor } \\
\text { HDAC inhibitor }\end{array}$ & $\begin{array}{l}\text { GSTP1, Akt, LAMTOR2, } \\
\text { LAMTOR3, LAMTOR5, } \\
\text { MAPK1, KRAS, HRAS, } \\
\text { MAPK3 }\end{array}$ & $\begin{array}{l}\downarrow \text { Cell proliferation } \\
\uparrow \text { Apoptosis } \\
\uparrow \text { Glucose uptake } \\
\uparrow \text { ASK1/JNK pathway } \\
\uparrow \text { ROS production }\end{array}$ & $\begin{array}{l}40-90 \mu \mathrm{M} \\
40-200 \mu \mathrm{M} \\
650 \mu \mathrm{M} \\
20-50 \mu \mathrm{M} \\
90 \mu \mathrm{M} \\
50 \mu \mathrm{M} \\
\end{array}$ & $\begin{array}{l}\text { Breast cancer (MCF-7, MDA-MB-231 Cells) } \\
\text { Liver cancer } \\
\text { Cervical cancer (SiHa cells) } \\
\text { Esophageal cancer } \\
\text { Prostate cancer (PC-3 cells) } \\
\text { Endometrial carcinoma (ECC-1 cells) }\end{array}$ & $\begin{array}{l}\text { Xenograft mice } \\
\text { Rats }\end{array}$ & [209-215] \\
\hline Kaempferol & $\begin{array}{l}\text { DNMT3a inhibitor } \\
\text { DNMT3b inhibitor } \\
\text { HDAC1 inhibitor }\end{array}$ & $\begin{array}{l}p-A k t, E R K, M S K 1, C D 1, \\
p 23, B T G 3, B R C A 1, \\
M G M T, \text { and } h M L H 1\end{array}$ & $\begin{array}{l}\uparrow \text { Apoptosis } \\
\downarrow \text { Glucose uptake } \\
\text { Autophagy } \\
\text { Cell cycle arrest }\end{array}$ & $\begin{array}{l}100 \mu \mathrm{M} \\
10-50 \mu \mathrm{M} \\
0-60 \mu \mathrm{M} \\
4 \mu \mathrm{M} \\
50 \mu \mathrm{M} \\
20 \mathrm{mg} / \mathrm{kg}\end{array}$ & $\begin{array}{l}\text { Liver cancer (SK-HEP-1 cells) } \\
\text { Lung cancer (A549 cells) } \\
\text { Colorectal cancer (HT-29 cells) } \\
\text { Breast cancer (MCF-7 cells) } \\
\text { Gastric cancer (G9a cells) } \\
\text { Gastric cancer (MKN28, SGC7901 and } \\
\text { GSE-1 cells) }\end{array}$ & $\begin{array}{l}\text { Athymic mice } \\
\text { Xenograft mice }\end{array}$ & [216-221] \\
\hline Luteolin & $\begin{array}{l}\text { DNMT inhibitor } \\
\text { HDAC inhibitor }\end{array}$ & VRK1, MPK2 & $\begin{array}{l}\uparrow \text { Apoptosis } \\
\text { Cell cycle arrest } \\
\text { Cell invasion }\end{array}$ & $\begin{array}{l}20-50 \mu \mathrm{M} \\
5-50 \mu \mathrm{M} \\
10-40 \mu \mathrm{M} \\
20-100 \mu \mathrm{M} \\
10 \mu \mathrm{M}\end{array}$ & $\begin{array}{l}\text { Esophageal cancer } \\
\text { Lung cancer (A549 cells) } \\
\text { Breast cancer (MCF-7 cells) } \\
\text { Colorectal cancer } \\
\text { Lung cancer (A549 cells) }\end{array}$ & Xenograft Mice & [222-227] \\
\hline Pterostilbene & $\begin{array}{l}\text { DNMT inhibitor } \\
\text { Decreased SIRT1 } \\
\text { activity }\end{array}$ & $\begin{array}{l}p 53, N F-\kappa B \text { and } \\
\text { miRNA4 } 88\end{array}$ & $\begin{array}{l}\uparrow \text { Apoptosis } \\
\text { Cell cycle arrest }\end{array}$ & $25-75 \mu \mathrm{M}$ & $\begin{array}{l}\text { Breast cancer (MCF-7 and MDA-MB-231 } \\
\text { cells) }\end{array}$ & Mice & {$[137,228-232]$} \\
\hline $\begin{array}{l}\text { Polyphenol- rich } \\
\text { Strawberry extract } \\
\text { (PRSE) }\end{array}$ & & $\begin{array}{l}\text { Csf1, Mcam, Nr4a3, } \\
\text { SET, Gpnmb, Itgb3, } \\
\text { CC17, Ctsl, Cxcr4, Htatip2, } \\
\text { Mmp-10 and Mmp3 }\end{array}$ & $\begin{array}{l}\downarrow \text { Cellular Viability } \\
\downarrow \text { Number of cells in S phase } \\
\text { Accumulation of cells in G1 } \\
\text { phase } \\
\downarrow \text { Tumor Weight } \\
\downarrow \text { Tumor Volume }\end{array}$ & $0.5-5 \mathrm{mg} / \mathrm{mL}$ & Breast Cancer (MCF-7 and A-17 cells) & Mice & [233] \\
\hline Genistein & $\begin{array}{l}\text { DNMT1 inhibitor } \\
\text { DNMT3a inhibitor } \\
\text { DNMT3b inhibitor } \\
\text { HDAC inhibitor } \\
\text { HAT activator } \\
\text { Decreased SIRT activity } \\
\text { Upregulation of histone } \\
\text { methylation }\end{array}$ & $\begin{array}{l}\text { p16INK4a; RAR } \beta ; M G M T ; \\
\text { PTEN; CYLD, MGMT, } \\
\text { CDKN2A, BTG3, TERT, } \\
\text { GSTP1, EZH 2, FoxM1, } \\
\text { sFRP1, p21, p16, PTEN, } \\
\text { CCLD, p53, FOXA3, SIRT1, } \\
\text { BTG3, hTERT, RAR, } \\
\text { HOTAIR }\end{array}$ & $\begin{array}{l}\downarrow \text { Proliferation } \\
\downarrow \text { Tumorigenesis } \\
\uparrow \text { Apoptosis } \\
\uparrow \text { mRNA expression of } \\
\text { tumor suppressor genes } \\
\uparrow \mathrm{H} 2 \mathrm{~A} \text { variant at serine } 139 \\
(\gamma-\mathrm{H} 2 \mathrm{AX})\end{array}$ & $\begin{array}{l}25-75 \mu \mathrm{M} \\
0.5-50 \mu \mathrm{M} \\
0.5-50 \mu \mathrm{M} \\
100 \mu \mathrm{M} \\
20-50 \mu \mathrm{mol} / \mathrm{L} \\
5-100 \mu \mathrm{M}\end{array}$ & $\begin{array}{l}\text { Lung cancer (H446 cells) } \\
\text { Breast cancer (MCF-7, MDA-MB-231 cell } \\
\text { lines) } \\
\text { Prostate cancer (LAPC-4 cells) } \\
\text { Cervical cancer } \\
\text { Esophageal squamous cell carcinoma } \\
\text { Prostate, breast cancer and renal cancer }\end{array}$ & $\begin{array}{l}\text { Agouti mice } \\
\text { Sprague-Dawley rats }\end{array}$ & [234-242] \\
\hline Gallic Acid & $\begin{array}{l}\text { DNMT1 inhibitor } \\
\text { DNMT3b inhibitor }\end{array}$ & $\begin{array}{l}\text { MMP-2, MMP-9, } \\
\text { ADAM17, Erk/p-Erk, p-Akt }\end{array}$ & $\uparrow$ Apoptosis & $\begin{array}{l}200 \mu \mathrm{M} \\
80.5 \mu \mathrm{M} \\
25-200 \mu \mathrm{M} \\
0-40 \mu \mathrm{g} / \mathrm{mL} \\
50 \mu \mathrm{M}\end{array}$ & $\begin{array}{l}\text { Colorectal cancer } \\
\text { Breast cancer (MCF-7 cells) } \\
\text { Prostate cancer (PC-3 cells) } \\
\text { Cervical cancer (HeLa and HTB-35 cells) } \\
\text { Oral cancer (H1299 cells) }\end{array}$ & & [243-247] \\
\hline
\end{tabular}


Table 2. Cont.

\begin{tabular}{|c|c|c|c|c|c|c|c|}
\hline $\begin{array}{l}\text { Dietary } \\
\text { Compounds }\end{array}$ & $\begin{array}{l}\text { Epigenetic } \\
\text { Modifications }\end{array}$ & Gene Targets & $\begin{array}{l}\text { *Overall Role in Cancer } \\
\text { Progression }\end{array}$ & Dose & In Vitro Model & In Vivo Model & References \\
\hline Naringenin & $\begin{array}{l}\text { DNMT1 inhibitor } \\
\text { DNMT3a inhibitor } \\
\text { DNMT3b inhibitor } \\
\text { HDAC1 inhibitor }\end{array}$ & $\begin{array}{l}\text { ATF3, PARP, p38, MMP-9, } \\
\text { ERK, Akt }\end{array}$ & $\begin{array}{l}\uparrow \text { Apoptosis } \\
\text { Cell cycle arrest } \\
\downarrow \text { Cell growth } \\
\downarrow \text { Cell proliferation }\end{array}$ & $\begin{array}{l}100 \mathrm{M} \mu \mathrm{M} \\
20-80 \mu \mathrm{M} \\
20 \text { or } 50 \\
\mu \mathrm{mol} / \mathrm{L} \\
25-200 \mu \mathrm{M} \\
50-100 \mu \mathrm{M}\end{array}$ & $\begin{array}{l}\text { Lung cancer (A549 cells) } \\
\text { Gastric cancer } \\
\text { Esophageal cancer (KYSE-510 cells) } \\
\text { Liver cancer (HepG2, Huh-7, and HA22T } \\
\text { cells) } \\
\text { Colorectal cancer (HCT116, SW480, Lovo, } \\
\text { and HT-29 cells) }\end{array}$ & $\begin{array}{l}\text { Resection mice } \\
\text { Rats }\end{array}$ & [248-251] \\
\hline Piceatannol & $\begin{array}{l}\text { DNMT3a inhibitor } \\
\text { Decreased SIRT1 } \\
\text { activity }\end{array}$ & $\begin{array}{l}\text { RASSF1A, GSTP1, HIN1 } \\
\text { mTOR }\end{array}$ & $\begin{array}{l}\uparrow \text { Apoptosis } \\
\text { Cell cycle arrest }\end{array}$ & $\begin{array}{l}30 \mu \mathrm{M} \\
25 \mu \mathrm{M} \\
50 \mu \mathrm{M}\end{array}$ & $\begin{array}{l}\text { Colorectal cancer (HCT116 and HT29 cells) } \\
\text { Prostate cancer (DU145 and PC-3 cells) } \\
\text { Breast cancer (MCF-7 cells) }\end{array}$ & Mice & {$[193,252-254]$} \\
\hline Quercetin & $\begin{array}{l}\text { DNMT1 inhibitor } \\
\text { HDAC inhibitor } \\
\text { Down-regulation of } \\
\text { histone demethylation }\end{array}$ & $\begin{array}{l}C D K N 2 A(p 16 I N K 4 a) \\
A M P K, A k t, D B H-A S 1, p 53\end{array}$ & $\begin{array}{l}\downarrow \text { Proliferation } \\
\downarrow \text { Akt phosphorylation } \\
\downarrow \text { Angiogenesis } \\
\uparrow \text { Caspase } 3 \text { and } 7 \text { activity } \\
\uparrow \text { Bax Activity } \\
\end{array}$ & $\begin{array}{l}1-200 \mu \mathrm{M} \\
40-160 \mu \mathrm{M}\end{array}$ & $\begin{array}{l}\text { Liver cancer (HepG2 and SMCC-7721 cells) } \\
\text { Lung cancer (A549 cells) } \\
\text { Gastric cancer (AGS and MKN28 cells) } \\
\text { Colon cancer (HCT116 cells) }\end{array}$ & Mice & {$[47,255-262]$} \\
\hline Xanthohumol & $\begin{array}{l}\text { DNMT inhibitor } \\
\text { HDAC inhibitor }\end{array}$ & CXCR4, CXCL12, p53 & $\begin{array}{l}\uparrow \text { Apoptosis } \\
\text { Cell cycle arrest } \\
\text { Cell Invasion } \\
\text { Cell proliferation } \\
\text { Cell migration }\end{array}$ & $\begin{array}{l}14-42 \mu \mathrm{M} \\
5-40 \mu \mathrm{M}\end{array}$ & $\begin{array}{l}\text { Lung cancer (A549 cells) } \\
\text { Liver cancer } \\
\text { Breast cancer } \\
\text { Prostate cancer (DU145 and PC3 cells) }\end{array}$ & Transgenic Mice & [263-267] \\
\hline Sulforaphane & $\begin{array}{l}\text { DNMT3a inhibitor } \\
\text { DNMT3b inhibitor } \\
\text { HDAC inhibitor } \\
\text { Upregulation of histone } \\
\text { phosphorylation }\end{array}$ & $\begin{array}{l}\text { NFE2L2, TERT, Nrf2, } \\
\text { ZEB1, COX-2/MMP-2, } \\
\text { 9/snail, p21, p27, RBP2 }\end{array}$ & $\begin{array}{l}\downarrow \text { Proliferation } \\
\uparrow \text { Apoptosis } \\
\text { Cell cycle arrest }\end{array}$ & $\begin{array}{l}50 \mu \mathrm{M} \\
5-10 \mu \mathrm{M} \\
0-30 \mu \mathrm{M}\end{array}$ & $\begin{array}{l}\text { Colorectal cancer } \\
\text { Breast cancer (MDA-MB-231 and MCF-7 } \\
\text { cells) } \\
\text { Bladder cancer (T24 cells and } 5637 \text { cells) }\end{array}$ & Xenograft Mice & [268-275] \\
\hline Resveratrol & $\begin{array}{l}\text { DNMT3a inhibitor } \\
\text { DNMT3b inhibitor } \\
\text { Decreased SIRT1, SIRT2, } \\
\text { and SIRT3 activity } \\
\text { HAT inhibitor } \\
\text { Regulation of histone } \\
\text { phosphorylation }\end{array}$ & $\begin{array}{l}\text { PTEN, XRCC1, p21 p16, } \\
\text { MDR1, SP-1, STIM1, } \\
\text { FOXO, PCGEM1, } \\
\text { PRNCR1, PCAT29, } \\
\text { AK001796, MALAT1, } \\
\text { u-Eleanor, LINC00978, p53, } \\
\text { p21 }\end{array}$ & $\begin{array}{l}\downarrow \text { Proliferation } \\
\uparrow \text { Apoptosis } \\
\downarrow \text { Metastasis } \\
\uparrow \text { Caspase } 8 / 9 \text { activity } \\
\uparrow \text { Bax Activity } \\
\downarrow \text { Bcl-2 Activity }\end{array}$ & $\begin{array}{l}50-150 \mu \mathrm{M} \\
5-50 \mu \mathrm{M} \\
50-200 \mu \mathrm{M} \\
20-150 \mu \mathrm{M} \\
25-100 \mu \mathrm{M} \\
150-250 \mu \mathrm{M} \\
25-100 \mu \mathrm{M}\end{array}$ & $\begin{array}{l}\text { Breast cancer (MCF-7 cells) } \\
\text { Lung cancer (H1703 and H1975 cells) } \\
\text { Gastric cancer (Ki67 cells) } \\
\text { Colon cancer (HT-29 cells, COLO } 21 \text { cells) } \\
\text { Prostate cancer (PC3 and DU145 cells) } \\
\text { Cervical cancer } \\
\text { Liver cancer (Huh7 cells) }\end{array}$ & Xenograft Mice & {$[179,276-288]$} \\
\hline
\end{tabular}




\section{Combinatorial Effect of Polyphenols on Cancer Prevention and Therapy}

A significant number of conventional methods are employed in cancer prevention or treatment. However, at some point, the tumor cells may develop resistance to various traditional methods such as radiotherapy and chemotherapy, thereby causing alterations in genes and proteins, which are involved in cancer progression. Therefore, combinatorial approaches can potentially be used in cancer prevention and therapy. These can be a combination of a polyphenol with two or more polyphenols, a combination of polyphenols with anti-cancer drugs, a combination of polyphenols with vitamin supplements or other efficacies in combination. These approaches can facilitate inhibition of tumor growth and in some cases the combined compounds can act synergistically. Here, we provide detailed information about various combinatorial approaches by different groups focusing on different types of cancer. These are summarized in the Table 3.

\subsection{Combinatorial Effect of Apigenin with Other Polyphenols and Anti-Cancer Drugs}

Many studies have reported various blockage in immune checkpoints that can lead to up-regulation of Interferon gamma (IFN $\gamma$ ) and further lead to tumor cell progression. A study was conducted demonstrating the combined action of apigenin and IFN $\gamma$. Primary cervical cancer HeLa and SiHa cells were co-administered with apigenin and IFN $\gamma$. This treatment resulted in enhancing the anticancer activity by targeting cyclin-dependent kinases 1 . The HeLa and SiHa cells were treated with different doses of apigenin and IFN $\gamma$. As a result, it was found that HeLa cells were more sensitive than SiHa cells, and cell viability was further reduced with the treatment of apigenin when co-partnered with IFN $\gamma$. This combination also increased the upregulation of a number of tumor related genes. Furthermore, apigenin increased the apoptosis-inducing effects of IFN $\gamma$ in HeLa cells but not in SiHa cells [289]. Paclitaxel is a chemotherapeutic FDA-approved drug used for the treatment of many different types of cancers such as ovarian, breast, lung, cervical and pancreatic cancer. Long-term administration of paclitaxel leads to the development of drug resistance and tumor progression. To overcome these, a combination of polyphenols such as apigenin can potentially be used. A study demonstrated the synergistic action of apigenin and paclitaxel in ovarian cancer. HeLa, A549, Hep3B, and HEK293A cells were treated with apigenin in combination with paclitaxel. As a result, both apigenin and paclitaxel induced apoptosis by eventually decreasing the number of surviving cells [290]. Cisplatin is a chemotherapeutic drug which is used in treating various cancers [291] and apigenin was also shown to amend cisplatin function in these cases. In human renal proximal tubular epithelial cells (HK-2cells), the combination of apigenin with cisplatin led to the reduction of p53 activation and further promoted the PI3K/Akt pathway. A study in prostate cancer in PC-3 cells and CSCs demonstrated a combined effect of apigenin and cisplatin by suppressing PI3K/AKT activation and protein expression of NF- $\mathrm{KB}[292,293]$.

Additionally, the combination of apigenin with doxorubicin induced a synergistic decrease in ATP levels in leukemia CCRF-CEM, Jurkat, and THP-1 cell lines. As a result, co-administration of apigenin and doxorubicin led to a decrease in ATP levels in three (CCRF-CEM, Jurkat and THP-1) out of four leukemia cell lines through enhancement in cell toxicity and DNA damage. This combination treatment also led to an increase in caspase-3 activity in all the four cell lines as well as cell cycle arrest and $\mathrm{S}$ and G2/M phase inhibition. Additionally, the combinatorial effect of apigenin and etoposide resulted in a decrease in ATP levels in the leukemia THP-1 myeloid cell line along with additive effects on other cell lines [294]. Another study was conducted in vitro in young adult mouse colonocyte cells (YMAC) to investigate the synergistic action of the two polyphenols. Higher concentrations of naringenin $(5 \mu \mathrm{M}$ and $10 \mu \mathrm{M})$ eradicated the growth of the cells, unlike apigenin, which abolished growth of the YMAC cells at a much lower concentration. However, the combination of apigenin and naringenin led to inhibition of YMAC cell growth, thereby causing activation of the estrogen receptor $(E R \beta)$ at a much lower concentration $(0.1+0.05-1 \mu \mathrm{M})$ [295]. In pancreatic cancer, apigenin along with gemcitabine enhanced anti-tumor effects. In vitro, this combined treatment of apigenin and gemcitabine led to a decrease in tumor cell growth and apoptosis by down-regulating NF-kappa B 
activity. The combination also resulted in the suppression of Akt activation in MiaPaca-2 and APC-1 cell lines. Collectively, these combinatorial studies have demonstrated a strong impact in different types of cancer and their associated molecular mechanisms [296].

\subsection{Combinatorial Effect of Curcumin with Other Polyphenols and Anti-Cancer Drugs}

Primary prostate cancer cells in B6C3F1/J mice when treated with the combination of curcumin and resveratrol increased the bioavailability by decreasing the tumor growth and inhibition of epithelial cell proliferation in contrast to curcumin administered alone. The combination of curcumin and resveratrol reduced prostate cancer by controlling the mean GU tract and decreasing the tumor weight of the mice [297]. Another study was conducted in vivo on the 1, 2-dimethylhydrazine (DMH) rat model in colorectal tumors and demonstrated the combinatorial effect on curcumin and catechins. The dietary treatment of curcumin, catechins and the combination of curcumin and catechin were administered in the positive and treated groups. As a result, although the incidence of the colorectal tumor was lower in the catechins and curcumin treatment groups, the difference was not significant when compared to the treatment groups when catechins and curcumin were administered alone. However, the frequency of the colorectal tumor was significantly lower in the combination group when compared to the positive groups. The study also demonstrated that the cell proliferation index (PI) was more significantly inhibited with the combination group (PI index: $24.2 \pm 9.02, p<0.01$ ) compared to the curcumin (PI index: $39.2 \pm 7.26, p<0.05$ ) and catechin (PI index: $36.8 \pm 5.50, p<0.05$ ) alone [298].

Another study in breast cancer (MCF-7 and Sum149 cells) demonstrated an improved bioavailability of curcumin and piperine in combination. Piperine (1-Piperoylpiperidine) is a dietary alkaloid which is mainly found in fruits and roots of black pepper [299]. This combination was known to be effective in cancer prevention by limiting stem cell self-renewal and inhibition of the Wnt signaling pathway. As a result, both curcumin and piperine inhibited mammosphere formation and serial passaging but the effect of inhibition was greater when both polyphenols were combined [300]. Curcumin also has positive effects with many other conventional therapies in breast cancer cells both in vitro and in vivo. In vitro, breast cancer MDA-MB-231 cells were more prone to inhibition by paclitaxel when combined with curcumin. In vivo, the 8-week-old athymic mice were administered with curcumin $(100 \mathrm{mg} / \mathrm{kg}$ daily), paclitaxel $(7 \mathrm{mg} / \mathrm{kg}$ weekly) and curcumin + paclitaxel. As a result, the combination treatment inhibited the growth of the cells to a more considerable extent compared to curcumin and paclitaxel alone. Eventually, curcumin inhibited the activity of NF-kB induced by paclitaxel, thereby increasing the apoptotic effect of paclitaxel [301].

Arcitgenin is a soluble plant extract of Arctium lappa which is used in Japanese Kampo medicine. Flavonoids such as curcumin and EGCG have reduced bioavailability when administered alone. Therefore, to overcome the reduced bioavailability of specific flavonoids, another study was conducted in breast cancer MCF-7 cells and prostate cancer LNCaP cells by administering a combination for $48 \mathrm{~h}$. As a result, both cells lines demonstrated a synergistic increment of antiproliferative effect. In MCF-7 cells, arctigenin increased the cell apoptosis of curcumin and EGCG enhanced the cell cycle arrest of curcumin. This combination also led to an increased expression of $\mathrm{Bax}-\mathrm{Bcl} 2$ proteins. Another study was conducted on non-small lung cancer (NSLC) A549 and NCI-H460 cells with the combination of low concentration of EGCG and curcumin. EGCG, when combined with curcumin, reduced the clonal formation in A549 cells. This combination heightened cell cycle arrest at G1 and S/G2 phase and inhibited cyclin D1 and cyclin B1. There was also a decrement in the tumor growth, thereby being a strong chemopreventive agent in NSLC. Also, the combination of curcumin $(50 \mu \mathrm{M})$ and EGCG $(100 \mu \mathrm{M})$ had a synergistic effect on prostate cancer LNCaP, DU145 and PC3 cells by causing the increased expression of $\mathrm{p} 21$, and cell cycle arrest at $\mathrm{S}$ and G2/M phase [302-306]. 
Table 3. Impact of combinatorial therapy (polyphenols, phytochemicals, and anti-cancer drugs) on epigenetic modifications and molecular mechanisms (in vivo and in vitro studies) in cancer.

\begin{tabular}{|c|c|c|c|c|c|c|c|}
\hline \multirow{2}{*}{ Combinatorial Therapy } & \multirow{2}{*}{ Organ of Study } & \multicolumn{2}{|l|}{ In Vitro Model } & \multicolumn{2}{|l|}{ In Vivo Model } & \multirow{2}{*}{$\begin{array}{l}\text { *Epigenetic Modifications and Molecular } \\
\text { Mechanism }\end{array}$} & \multirow{2}{*}{ References } \\
\hline & & Cell Lines & Dose & & & & \\
\hline Apigenin + IFN $\gamma$ & Cervical cancer & HeLa and SiHa cells & $5-15 \mu \mathrm{M}+100 \mathrm{ng} / \mathrm{mL}$ & & & $\begin{array}{l}\downarrow \text { Cell viability } \\
\uparrow \text { Apoptosis } \\
\text { Up-regulation of } \\
\text { DNMT1 }\end{array}$ & [289] \\
\hline Apigenin + Paclitaxel & Ovarian cancer & $\begin{array}{l}\text { HeLa, A549, Hep3B and } \\
\text { HEK293A cells }\end{array}$ & $15 \mu \mathrm{M}+4 \mathrm{nM}$ & & & $\begin{array}{l}\text { Apoptosis through suppressing SOC activity } \\
\uparrow \text { ROS and caspase- } 2 \text { cleavage. }\end{array}$ & {$[290]$} \\
\hline \multirow[t]{2}{*}{ Apigenin + Cisplatin } & Renal cancer & $\begin{array}{l}\text { Human renal proximal } \\
\text { tubular epithelial (HK-2) } \\
\text { cells }\end{array}$ & $5-20 \mu \mathrm{M}+40 \mu \mathrm{M}$ & & & $\begin{array}{l}\text { Apigenin reduced cisplatin-induced caspase- } 3 \\
\text { activity and PARP cleavage } \\
\downarrow \text { ROS production and p53 activation } \\
\text { Akt phosphorylation }\end{array}$ & [293] \\
\hline & Prostate cancer & PC3 PCa cells & $15 \mu \mathrm{M}+7.5 \mu \mathrm{M}$ & & & $\begin{array}{l}\text { Upregulation of } \\
\text { Caspase-8, Apaf- } 1 \text { and p53 } \\
\text { Down-regulation of Snail expression. } \\
\text { Repressed phosphorylation of p-PI3K and } \\
\text { p-Akt }\end{array}$ & [292] \\
\hline Apigenin + doxorubicin & Lymphoid leukemia & $\begin{array}{l}\text { CCRF, CEM, Jurkat and } \\
\text { THP- } 1 \text { cells }\end{array}$ & $0.01 \mu \mathrm{M}+0.4 \mu \mathrm{M}$ & & & $\begin{array}{l}\uparrow \text { caspase- } 3 \text { activity } \\
\text { Cell cycle arrest at } \mathrm{S} \text { and G2/M phase } \\
\uparrow \text { DNA damage }\end{array}$ & [294] \\
\hline Apigenin + etoposide & & & & & & $\begin{array}{l}\uparrow \text { caspase- } 3 \text { activity } \\
\uparrow \text { caspase- } 8 \text { activity } \\
\uparrow \text { caspase }-9 \text { activity }\end{array}$ & [294] \\
\hline Apigenin + Naringenin & Colon cancer & & & Mice & $0.1 \mu \mathrm{M}+0.05 \mu \mathrm{M}$ & $\begin{array}{l}\uparrow \text { ER-mediated YAMC cell growth } \\
\uparrow \text { activation of ER } \beta\end{array}$ & [295] \\
\hline Apigenin + Gemcitabine & Pancreatic cancer & $\begin{array}{l}\text { MiaPaca-2, AsPC-1 cell } \\
\text { lines }\end{array}$ & $30 \mu \mathrm{M}+05-2 \mu \mathrm{M}$ & Xenograft mice model & & $\begin{array}{l}\text { Down-regulation of NF-kB activity } \\
\text { Suppression of Akt activation }\end{array}$ & [296] \\
\hline Curcumin + Resveratrol & Prostate cancer & PTEN-CaP8 cancer cells & & B6C3F1/J mice & & $\downarrow \mathrm{p}-A k t$, and cyclin D1 activity & [297] \\
\hline Curcumin + Catechins & Colon cancer & & & DMH rat model & $0.1 \%+0.1 \%$ & $\begin{array}{l}\uparrow \text { Apoptotic index } \\
\downarrow \text { Proliferation index }\end{array}$ & {$[298]$} \\
\hline Curcumin + Piperine & Breast cancer & MCF-7 and Sum159 cells & $5-25 \mu \mathrm{M}+5-25 \mu \mathrm{M}$ & & & $\begin{array}{l}\text { Inhibit mammosphere formation } \\
\downarrow \text { stem cell self-renewal } \\
\downarrow \text { in the cell percentage expressing stem cell } \\
\text { marker ALDH1 } \\
\text { Inhibit Wnt Signaling }\end{array}$ & {$[300]$} \\
\hline Curcumin + Paclitaxel & Breast cancer & MDA-MB-231 cells & $10 \mu \mathrm{M}+10 \mu \mathrm{M}$ & Nude mice model & $\begin{array}{l}100 \mathrm{mg} / \mathrm{kg}+7 \\
\mathrm{mg} / \mathrm{kg}\end{array}$ & $\begin{array}{l}\text { Inhibition of tumor cell growth } \\
\downarrow \text { Tumor size } \\
\downarrow \text { Tumor cell proliferation } \\
\uparrow \text { Expression of } M M P-9\end{array}$ & {$[301]$} \\
\hline
\end{tabular}


Table 3. Cont.

\begin{tabular}{|c|c|c|c|c|c|c|c|}
\hline \multirow{2}{*}{ Combinatorial Therapy } & \multirow{2}{*}{ Organ of Study } & \multicolumn{2}{|l|}{ In Vitro Model } & \multicolumn{2}{|l|}{ In Vivo Model } & \multirow{2}{*}{$\begin{array}{l}\text { *Epigenetic Modifications and Molecular } \\
\text { Mechanism }\end{array}$} & \multirow{2}{*}{ Reference } \\
\hline & & Cell Lines & Dose & & & & \\
\hline \multirow{2}{*}{$\begin{array}{l}\text { Curcumin }+ \text { Arctigenin }+ \\
\text { Green tea }+ \\
\text { Epigallocatechin gallate } \\
\text { (EGCG) }\end{array}$} & Prostate cancer & LNCaP cells & $\begin{array}{l}5-10 \mu \mathrm{M}+1 \mu \mathrm{M}+40 \\
\mu \mathrm{M}\end{array}$ & & & \multirow{2}{*}{$\begin{array}{l}\uparrow \text { Apoptosis } \\
\uparrow \text { Cell cycle arrest at G0/G1 phase } \\
\downarrow \text { Activation of } N F \kappa B, P I 3 K / A k t \text { and Stat } 3 \\
\text { pathways } \\
\downarrow \text { Cell migration }\end{array}$} & \multirow[t]{2}{*}[303]{} \\
\hline & Breast cancer & MCF-7 cells & $\begin{array}{l}5-10 \mu \mathrm{M}+1 \mu \mathrm{M}+40 \\
\mu \mathrm{M}\end{array}$ & & & & \\
\hline \multirow[t]{2}{*}{$\begin{array}{l}\text { Curcumin }+ \\
\text { Epigallocatechin gallate } \\
\text { (EGCG) }\end{array}$} & Non-small lung cancer & A549 and NCI-H460 cells & $10 \mu \mathrm{mol} / \mathrm{L}+10 \mu \mathrm{mol} / \mathrm{L}$ & & & $\begin{array}{l}\downarrow \text { Tumor size } \\
\text { Cell cycle arrest at G1 and S/G2 phase } \\
\text { Inhibition of expression of cyclin B1 and cyclin } \\
\text { D1 } \\
\text { Inhibition of clonal formation } \\
\text { Down-regulation of DNMTs }\end{array}$ & \multirow[t]{2}{*}[304,305]{} \\
\hline & Prostate cancer & $\begin{array}{l}\text { LNCaP, DU145 and PC3 } \\
\text { cells }\end{array}$ & $50 \mu \mathrm{M}+100 \mu \mathrm{M}$ & & & $\begin{array}{l}\uparrow \mathrm{p} 21 \text { expression } \\
\text { Cell cycle arrest at S, G2/M phase }\end{array}$ & \\
\hline Curcumin + Dasatinib & Colon cancer & $\begin{array}{l}\text { HCT-116, HT-29 and } \\
\text { SW- } 620\end{array}$ & & $\mathrm{APC}^{\mathrm{Min}+/-}$ mice & & $\begin{array}{l}\downarrow \text { Cell proliferation } \\
\uparrow \text { Apoptosis } \\
\uparrow \text { Invasion through the extracellular matrix } \\
\uparrow \text { Tubule formation by endothelial cells }\end{array}$ & {$[306]$} \\
\hline Curcumin + TRAIL & Prostate cancer & LNCaP cells & & PC3 cells & & $\begin{array}{l}\uparrow \text { Apoptosis } \\
\uparrow \text { MMP-9, MMP-2, caspase-3, and caspase-9 } \\
\text { activity }\end{array}$ & {$[307,308]$} \\
\hline Curcumin + Gemcitabine & Pancreatic cancer & & & $\begin{array}{l}\text { BxPC3, MiaPaCa2 and } \\
\text { Panc1 PDAC cells }\end{array}$ & $\begin{array}{l}100 \mathrm{mg} / \mathrm{kg}+25 \\
\mathrm{mg} / \mathrm{kg}\end{array}$ & $\begin{array}{l}\downarrow \text { Tumor growth } \\
\downarrow N F-\kappa B \text { activity } \\
\downarrow \text { VFGF expression }\end{array}$ & [309] \\
\hline $\begin{array}{l}\text { Genistein + Delphinidin + } \\
\text { Alternariol (AOH) }\end{array}$ & Colon cancer & HT-29 cells & $\begin{array}{l}25 \mu \mathrm{M}+100 \mu \mathrm{M}+50 \\
\mu \mathrm{M}\end{array}$ & & & $\begin{array}{l}\uparrow \text { Cytotoxic effect } \\
\uparrow \text { Genotoxicity effect } \\
\uparrow \text { Topoisomerase poisoning } \\
\downarrow \text { ROS generation } \\
\end{array}$ & {$[310]$} \\
\hline Genistein + Erlotinib & Bladder cancer & A431 cells & $100 \mu \mathrm{M}+10 \mathrm{nM}$ & & & $\begin{array}{l}\text { Inhibitor of EGFRs } \\
\text { Overexpression of RTKs }\end{array}$ & [311] \\
\hline Genistein + Sulforaphane & Breast cancer & $\begin{array}{l}\text { MCF-7 and MDA-MB-231 } \\
\text { cells }\end{array}$ & $5 \mu \mathrm{M}+10-15 \mu \mathrm{M}$ & & & $\begin{array}{l}\text { Cell cycle arrest at G1 and G2/M phase } \\
\downarrow \text { Cell viability } \\
\uparrow \text { Apoptosis }\end{array}$ & {$[312]$} \\
\hline Genistein + Cisplatin & \multirow[t]{3}{*}{ Breast cancer } & \multirow[t]{3}{*}{ MCF-7 and T47D cells } & $1 \mu \mathrm{M}+10 \mu \mathrm{M}$ & & & \multirow{3}{*}{$\begin{array}{l}\downarrow \text { ROS production } \\
\uparrow \text { Cell viability } \\
\downarrow \text { Autophagy } \\
\downarrow \text { Apoptosis } \\
\text { Cell cycle arrest at } \text { subG }_{0} / \mathrm{G}_{1} \text { phase }\end{array}$} & \multirow[t]{3}{*}[313]{} \\
\hline Genistein + Tamoxifen & & & $1 \mu \mathrm{M}+10 \mu \mathrm{M}$ & & & & \\
\hline Genistein + Paclitaxel & & & $1 \mu \mathrm{M}+10 \mu \mathrm{M}$ & & & & \\
\hline Genistein + Resveratrol & Prostate cancer & & & Rats & $\begin{array}{l}83 \mathrm{mg} / \mathrm{kg}+83 \\
\mathrm{mg} / \mathrm{kg}\end{array}$ & $\begin{array}{l}\downarrow \text { Tumor growth } \\
\text { Inhibition of Growth factors }\end{array}$ & {$[314]$} \\
\hline
\end{tabular}


Table 3. Cont

\begin{tabular}{|c|c|c|c|c|c|c|c|}
\hline \multirow{2}{*}{ Combinatorial Therapy } & \multirow{2}{*}{ Organ of Study } & \multicolumn{2}{|l|}{ In Vitro Model } & \multicolumn{2}{|l|}{ In Vivo Model } & \multirow{2}{*}{$\begin{array}{l}\text { *Epigenetic Modifications and Molecular } \\
\text { Mechanism }\end{array}$} & \multirow{2}{*}{ Reference } \\
\hline & & Cell Lines & Dose & & & & \\
\hline $\begin{array}{l}\text { Genistein + Quercetin + } \\
\text { Biochanin A }\end{array}$ & Prostate cancer & $\begin{array}{l}\text { PC-3, LNCaP, DU-145 } \\
\text { cells }\end{array}$ & $\begin{array}{l}8.33 \mu \mathrm{M}+8.33 \mu \mathrm{M}+ \\
8.33 \mu \mathrm{M}\end{array}$ & & & $\begin{array}{l}\uparrow \text { BAX/BCL-2 activity } \\
\uparrow \text { caspase-3 activity } \\
\uparrow \text { ER- } \beta \text { activity } \\
\uparrow \text { p-JNK activity } \\
\downarrow \text { p-ERK activity } \\
\downarrow \text { PCNA activity } \\
\downarrow \text { Cell proliferation } \\
\uparrow \text { Apoptosis }\end{array}$ & {$[315]$} \\
\hline $\begin{array}{l}\text { Genistein + EGCG + } \\
\text { quercetin }\end{array}$ & Prostate cancer & CWR22Rv1 cells & $\begin{array}{l}2.5 \mu \mathrm{M}+2.5 \mu \mathrm{M}+2.5 \\
\mu \mathrm{M}\end{array}$ & & & $\begin{array}{l}\uparrow p 53 \text { activity } \\
\downarrow \text { cell proliferation }\end{array}$ & {$[316]$} \\
\hline $\begin{array}{l}\text { Resveratrol + } \\
\text { Thymoquinone }\end{array}$ & Breast cancer & MCF-7 and T47D cells & $10 \mu \mathrm{M}+25-300 \mu \mathrm{M}$ & Balb/C mice & $\begin{array}{l}50 \mathrm{mg} / \mathrm{kg}+50 \\
\mathrm{mg} / \mathrm{kg} \text { per day }\end{array}$ & $\begin{array}{l}\uparrow \text { Apoptosis, } \\
\downarrow \text { Tumor growth } \\
\text { Inhibition of angiogenesis }\end{array}$ & {$[317]$} \\
\hline Resveratrol + Quercetin & Prostate cancer & $\begin{array}{l}\text { 22R } v 1, \text { DU145 and PC3 } \\
\text { cells }\end{array}$ & & TRAMP mice model & $\begin{array}{l}625 \mathrm{mg} / \mathrm{kg}+60 \\
\mathrm{mg} / \mathrm{kg}\end{array}$ & $\downarrow$ Cell proliferation & {$[318]$} \\
\hline $\begin{array}{l}\text { Resveratrol + Curcumin + } \\
\text { ADR }\end{array}$ & Ovarian cancer & A2780 cells & $10 \mu \mathrm{M}+2 \mu \mathrm{M}+1 \mu \mathrm{M}$ & $\begin{array}{l}\text { Xenograft model in } \\
\text { Athymic mice }\end{array}$ & $\begin{array}{l}19.68 \mathrm{mg} / \mathrm{kg}+ \\
26.06 \mathrm{mg} / \mathrm{kg}+ \\
5 \mathrm{mg} / \mathrm{kg}\end{array}$ & $\begin{array}{l}\downarrow \text { Cell viability } \\
\downarrow \text { Tumor size } \\
\uparrow \text { Apoptosis }\end{array}$ & [319] \\
\hline $\begin{array}{l}\text { Resveratrol + Quercetin + } \\
\text { ADR }\end{array}$ & Ovarian cancer & A2780 cells & $10 \mu \mathrm{M}+10 \mu \mathrm{M}+1 \mu \mathrm{M}$ & $\begin{array}{l}\text { Xenograft model in } \\
\text { Athymic mice }\end{array}$ & $\begin{array}{l}19.68 \mathrm{mg} / \mathrm{kg}+5.2 \\
\mathrm{mg} / \mathrm{kg}+5 \mathrm{mg} / \mathrm{kg}\end{array}$ & $\begin{array}{l}\downarrow \text { Cell viability } \\
\downarrow \text { Tumor size } \\
\uparrow \text { Apoptosis }\end{array}$ & {$[319]$} \\
\hline Resveratrol + Doxorubicin & Gastric cancer & $\begin{array}{l}\mathrm{SGC}_{7901} \text { and MGC } 803 \text { cell } \\
\text { lines }\end{array}$ & $50 \mathrm{mg} / \mathrm{L}+0.75 \mathrm{mg} / \mathrm{L}$ & $\begin{array}{l}\text { Nude xenograft mice } \\
\text { model }\end{array}$ & $\begin{array}{l}3 \mathrm{mg} / \mathrm{kg}+50 \\
\mathrm{mg} / \mathrm{kg} \$\end{array}$ & $\begin{array}{l}\uparrow \text { expression of caspase } 9 \\
\uparrow \text { PTEN, TSC1, TSC2, and cleaved caspase } 3 \\
\downarrow \text { p- } A k T \text {, and mTOR activity }\end{array}$ & {$[320]$} \\
\hline $\begin{array}{l}\text { Resveratrol + Genistein + } \\
\text { Quercetin + Apigenin + } \\
\text { Baicalein + Curcumin + } \\
\text { EGCG }\end{array}$ & Prostate cancer & PC3 and LNCaP cells & & TRAMP mice model & $\begin{array}{l}1 \mu \mathrm{mol} / \mathrm{L}+20 \\
\mu \mathrm{mol} / \mathrm{l}+10 \\
\mu \mathrm{mol} / \mathrm{L}+3 \\
\mu \mathrm{mol} / \mathrm{L}+3 \\
\mu \mathrm{mol} / \mathrm{L}+10 \\
\mu \mathrm{mol} / \mathrm{L}+10 \\
\mu \mathrm{mol} / \mathrm{L}\end{array}$ & $\downarrow$ GLi1 mRNA activity $\$$ Tumor size & [321] \\
\hline $\begin{array}{l}\text { Resveratrol + } \\
\text { Pomegranate + Orange + } \\
\text { Lemon + Olive + Cocoa + } \\
\text { Grape seed }\end{array}$ & Breast Cancer & MCF-7 cells & & & $\begin{array}{l}53.85 \mathrm{mg}+161.5 \\
\mathrm{mg}+53.85 \mathrm{mg}+ \\
53.85 \mathrm{mg}+161.5 \\
\mathrm{mg}+161.5 \mathrm{mg}+ \\
53.85 \mathrm{mg}\end{array}$ & $\begin{array}{l}\downarrow \text { Anti-proliferative activity } \$ \downarrow \text { Estrogenic } \\
\text { estrogenic/anti-esterogenic activity }\end{array}$ & {$[323]$} \\
\hline EGCG + Sunitinib & $\begin{array}{l}\text { Breast cancer } \\
\text { Non-small cell lung } \\
\text { cancer }\end{array}$ & $\begin{array}{l}\text { H460, H1975, and MCF-7 } \\
\text { cells }\end{array}$ & $50 \mu \mathrm{M}+3 \mu \mathrm{M}$ & Xenograft mice model & $\begin{array}{l}50 \mathrm{mg} / \mathrm{kg}+40 \\
\mathrm{mg} / \mathrm{kg}\end{array}$ & Suppression of IRS/MAPK/p-S6K1 signaling & {$[324]$} \\
\hline
\end{tabular}


Table 3. Cont

\begin{tabular}{|c|c|c|c|c|c|c|c|}
\hline \multirow{2}{*}{ Combinatorial Therapy } & \multirow{2}{*}{ Organ of Study } & \multicolumn{2}{|l|}{ In Vitro Model } & \multicolumn{2}{|l|}{ In Vivo Model } & \multirow{2}{*}{$\begin{array}{l}\text { *Epigenetic Modifications and Molecular } \\
\text { Mechanism }\end{array}$} & \multirow{2}{*}{ References } \\
\hline & & Cell Lines & Dose & & & & \\
\hline $\begin{array}{l}\text { Resveratrol + Quercetin + } \\
\text { Catechin + Gefitinib }\end{array}$ & Breast cancer & MDA-MB-231 cells & $\begin{array}{l}15 \mu \mathrm{M}+15 \mu \mathrm{M}+15 \\
\mu \mathrm{M}+15 \mu \mathrm{M}\end{array}$ & SCID mice model & $\begin{array}{l}5 \mathrm{mg} / \mathrm{kg}+5 \mathrm{mg} / \mathrm{kg} \\
+5 \mathrm{mg} / \mathrm{kg}+5 \\
\mathrm{mg} / \mathrm{kg}+200 \\
\mathrm{mg} / \mathrm{kg}\end{array}$ & $\begin{array}{l}\downarrow \text { Tumor size } \\
\text { Cell cycle arrest at } S \text { phase } \\
\downarrow \text { Cell viability } \\
\text { Inhibition of Akt/mTOR signaling }\end{array}$ & {$[322]$} \\
\hline \multirow[t]{2}{*}{$\begin{array}{l}\text { EGCG + } \\
\text { Vitexin-2-O-xyloside + } \\
\text { Glucoraphasatin }\end{array}$} & Breast cancer & $\begin{array}{l}\text { MDA-MB-231 cells } \\
\text { MCF-7 cells }\end{array}$ & $\begin{array}{l}(1980 \pm 94) \mu \mathrm{g} / \mathrm{mL}+ \\
(1200 \pm 66) \mu \mathrm{g} / \mathrm{mL}+ \\
(21 \pm 6) \mu \mathrm{g} / \mathrm{mL}+(350 \\
\pm 47) \mu \mathrm{g} / \mathrm{mL}+(350 \pm \\
48) \mu \mathrm{g} / \mathrm{mL}+(31 \pm 4) \\
\mu \mathrm{g} / \mathrm{mL}\end{array}$ & & & \multirow{2}{*}{$\begin{array}{l}\text { Induction of apoptosis } \\
\text { Cell cycle arrest at } \\
\text { Regulation of Bcl2, Bax, cleaved caspase- } 9 \text { and } \\
\text { PARP } \\
\uparrow \text { ROS production }\end{array}$} & \multirow[t]{2}{*}{ [325] } \\
\hline & Colorectal cancer & $\begin{array}{l}\text { Caco- } 2 \text { cells } \\
\text { LoVo cell }\end{array}$ & $\begin{array}{l}(21 \pm 3) \mu \mathrm{g} / \mathrm{mL}+(120 \\
\pm 9) \mu \mathrm{g} / \mathrm{mL}+(16 \pm 4) \\
\mu \mathrm{g} / \mathrm{mL}+(135 \pm 16) \\
\mu \mathrm{g} / \mathrm{mL}+(158 \pm 13) \\
\mu \mathrm{g} / \mathrm{mL}+(36 \pm 5) \\
\mu \mathrm{g} / \mathrm{mL}\end{array}$ & & & & \\
\hline EGCG + NAC & Lung cancer & H1299 cells & $100 \mu \mathrm{M}+2 \mathrm{mM}$ & CL13 mice & & $\begin{array}{l}\uparrow \text { Apoptosis } \\
\uparrow \text { ROS production }\end{array}$ & {$[326]$} \\
\hline EGCG + Pterostilbene & Pancreatic cancer & $\begin{array}{l}\text { PANC-1 and MIA-Pa-Ca-2 } \\
\text { cells }\end{array}$ & $20-40 \mu \mathrm{M}+30 \mu \mathrm{M}$ & & & $\begin{array}{l}\downarrow \text { Cell proliferation } \\
\text { Cell cycle arrest at } \mathrm{S} \text { phase } \\
\uparrow \text { caspase- } 3 / 7 \text { activity }\end{array}$ & {$[327]$} \\
\hline EGCG + TRAIL & Pancreatic cancer & MIA-Pa-Ca-2 cells & $50 \mu \mathrm{g} / \mathrm{mL}+5 \mathrm{ng} / \mathrm{mL}$ & & & $\begin{array}{l}\uparrow \text { Apoptosis } \\
\uparrow \text { Activation of caspase- } 8 \text { and caspase- }-9\end{array}$ & {$[328]$} \\
\hline EGCG + 5- Fluorouracil & Colorectal cancer & HCT-116 and SW480 cells & $\begin{array}{l}25-400 \mu \mathrm{M}+2.5-40 \\
\mu \mathrm{M}\end{array}$ & Xenograft mice model & & $\begin{array}{l}\downarrow \text { miR-34a, miR-145, and miR-200c } \\
\text { Cell cycle arrest } \\
\downarrow \text { Notch1, Bmi1, Suz12, and Ezh2 activity }\end{array}$ & [329] \\
\hline EGCG + 5- Fluorouracil & Colorectal cancer & HCT-116 and SW480 cells & $\begin{array}{l}25-400 \mu \mathrm{M}+2.5-40 \\
\mu \mathrm{M}\end{array}$ & Xenograft mice model & & $\begin{array}{l}\downarrow \text { miR-34a, miR-145, and miR-200c } \\
\uparrow \text { spheroid formation } \\
\downarrow \text { Notch1, Bmi1, Suz12, and Ezh2 activity } \\
\text { Cell cycle arrest at G0/G1 phase }\end{array}$ & [329] \\
\hline $\begin{array}{l}\text { Sulforaphane + Green tea } \\
\text { polyphenols (GTPs) }\end{array}$ & Breast cancer & MDA-MB-231 cells & $5-10 \mu \mathrm{M}+20 \mu \mathrm{g} / \mathrm{mL}$ & & & $\begin{array}{l}\text { Reactivation of Tumor suppressor genes } \\
\text { (TSGs) } p 21^{C I P 1 / W A F 1} \text { and KLOTHO } \\
\text { Cell cycle arrest at G2/M phase } \\
\downarrow \text { CDK1 and CDC25C expressions } \\
\text { Inhibition of IGF- } 1 \text { pathways }\end{array}$ & {$[330]$} \\
\hline $\begin{array}{l}\text { Sulforaphane + } \\
\text { Withaferin-A }\end{array}$ & Breast cancer & $\begin{array}{l}\text { MCF-7 and MDA-MB-231 } \\
\text { cells }\end{array}$ & $5 \mu \mathrm{M}+10 \mu \mathrm{M}$ & & & $\begin{array}{l}\downarrow H D A C 1 \\
\text { Inhibition of DNMT1, DNMT3A, and DNMT3B } \\
\uparrow \text { Apoptosis } \\
\downarrow \text { BAX/BCL-2 activity }\end{array}$ & [331] \\
\hline
\end{tabular}


Table 3. Cont.

\begin{tabular}{|c|c|c|c|c|c|c|c|}
\hline \multirow{2}{*}{ Combinatorial Therapy } & \multirow{2}{*}{ Organ of Study } & \multicolumn{2}{|l|}{ In Vitro Model } & \multicolumn{2}{|l|}{ In Vivo Model } & \multirow{2}{*}{$\begin{array}{l}\text { "Epigenetic Modifications and Molecular } \\
\text { Mechanism }\end{array}$} & \multirow{2}{*}{ Reference } \\
\hline & & Cell Lines & Dose & & & & \\
\hline Sulforaphane + Curcumin & Liver cancer & HepG2-C8 cells & $\begin{array}{l}\text { Low dose: } 12.5 \mu \mathrm{M}+ \\
10 \mu \mathrm{M} \\
\text { High dose: } 50 \mu \mathrm{M}+ \\
25 \mu \mathrm{M}\end{array}$ & & & $\begin{array}{l}\uparrow \text { ARE-luciferase activity } \\
\uparrow \text { Expression of HO-1 and UGT1A1 } \\
\uparrow N r f 2 \text { mRNA levels }\end{array}$ & {$[332]$} \\
\hline \multirow{3}{*}{ Sulforaphane + EGCG } & Prostate cancer & PC-3-AP-1 cells & $\begin{array}{l}\text { Low Dose: } 25 \mu \mathrm{mol} / \mathrm{L} \\
+20 \mu \mathrm{mol} / \mathrm{L} \\
\text { High Dose: } 25 \mu \mathrm{mol} / \mathrm{L} \\
+\mu \mathrm{mol} / \mathrm{L}\end{array}$ & Nrf2-deficient mice & $\begin{array}{l}45 \mathrm{mg} / \mathrm{kg}+100 \\
\mathrm{mg} / \mathrm{kg}\end{array}$ & $\begin{array}{l}\text { Inhibition of AP- } 1 \text { activity } \\
\text { Down-regulation of Nrf2-dependent genes }\end{array}$ & {$[334]$} \\
\hline & Ovarian cancer & $\begin{array}{l}\text { SKOV-ip1 and } \\
\text { SKOVTR-ip2 cells }\end{array}$ & $10 \mu \mathrm{M}+20 \mu \mathrm{M}$ & & & $\begin{array}{l}\uparrow \text { Expression of } h T E R T, D N M T 1 \\
\downarrow \text { Cell viability } \\
\text { Cell cycle arrest in } \mathrm{G}_{2} / \mathrm{M} \text { and } \mathrm{S} \text { phases } \\
\uparrow \text { Apoptosis }\end{array}$ & {$[333]$} \\
\hline & Colon cancer & HT-29 cells & $\begin{array}{l}\text { Low Dose: } 25 \mu \mathrm{M}+20 \\
\mu \mathrm{M} \\
\text { High Dose: } 10 \mu \mathrm{M}+ \\
20 \mu \mathrm{M}\end{array}$ & & & $\begin{array}{l}\downarrow \text { Cell viability } \\
\uparrow \text { AP- } 1 \text { activity }\end{array}$ & {$[335]$} \\
\hline $\begin{array}{l}\text { Sulforaphane }+ \\
\text { Acetazolamide (AZ) }\end{array}$ & Urothelial cancer & HTB-9 and RT112(H) cells & $40 \mu \mathrm{M}+40 \mu \mathrm{M}$ & & & $\begin{array}{l}\uparrow \text { Apoptosis } \\
\downarrow \text { Ki-67, pHH3, cyclin D1 activity } \\
\text { Cell cycle arrest } \\
\text { Inhibition of } A k t \text { kinase activity } \\
\text { Downregulation of p-Akt (Ser473) and } p \text {-S6 } \\
\text { activity }\end{array}$ & {$[336]$} \\
\hline $\begin{array}{l}\text { Sulforaphane + Docetaxel } \\
\text { + Paclitaxel }\end{array}$ & Breast cancer & $\begin{array}{l}\text { SUM149 and SUM159 } \\
\text { cells }\end{array}$ & $5 \mu \mathrm{M}+0-20 \mu \mathrm{M}$ & Xenograft mice model & $\begin{array}{l}50 \mathrm{mg} / \mathrm{kg} \text { daily }+ \\
10 \mathrm{mg} / \mathrm{kg} \text { weekly }\end{array}$ & $\begin{array}{l}\downarrow \text { Tumor growth } \\
\text { Inhibition of NF-kB p65 translocation }\end{array}$ & \\
\hline
\end{tabular}


Primary colon cancer cells are commonly treated with the drug dasatinib, which is a small molecule-inhibitor of the SRC-family of protein kinases. Sustained chemotherapeutic treatment with this drug results in drug resistance and tumor progression. Therefore, to prevent these harmful effects, dasatinib when combined with curcumin using in vitro and in vivo models, resulted in the enhanced inhibition of various metastatic processes. In vivo, this combination enhanced the cell adhesion phenotype of colon cancer HCT-116 cells. In vitro, this combination led to a 95\% regression of intestinal adenomas in $\mathrm{APC}^{\mathrm{Min+}+-}$ mice, thereby decreasing tumor proliferation and increasing apoptosis [306]. TNF-related apoptosis-inducing ligand (TRAIL) is a tumor necrosis factor (TNF) gene which possesses apoptosis-inducing activity against cancer cells in vivo and in vitro. Despite this functionality, the defects in intrinsic and extrinsic pathways (such as Akt and NF-KB pathways) could potentially cause cell resistance thereby affecting its functional role. Thus far, the combinatorial approach of TRAIL with curcumin can cause synergistic action in prostate cancer PC 3 cells. This combination caused suppression of NF- $\mathrm{kB}$ activity through Akt pathways, and further inhibition of $\mathrm{Bcl}-2, \mathrm{Bcl}-\mathrm{XL}$, and XIAP expression. In vivo, when this was administered to xenografted mice with prostate LNCAP cells, the inhibition of tumor growth, increased apoptotic activity, and further activation of anti-proliferative, anti-angiogenic, and anti-metastatic mechanisms were observed [307,308]. Gemcitabine is a chemotherapeutic drug which is known to treat various types of cancer such as those of bladder, pancreatic and breast. Like Dasatinib, this drug also results in drug resistance. When gemcitabine $(25 \mathrm{mg} / \mathrm{kg}$ body weight once every four weeks) is used in combination with curcumin $(100 \mathrm{mg} / \mathrm{kg}$ body weight daily) in pancreatic cancer $\mathrm{BxPC} 3, \mathrm{MiaPaCa} 2$ and Panc1 PDAC cells, it inhibited tumor growth thereby inhibiting expression of PRC2 subunit EZH2 and lncRNA PVT1. This combination also suppressed the spheroid-forming capability of tumor cells [309].

\subsection{Combinatorial Effect of Genistein with Other Polyphenols and Anti-Cancer Drugs}

The primary mechanism of genistein is to induce DNA strand breaks and oxidative stress. On the other hand, delphinidin suppresses DNA-damaging properties and possess anti-oxidative properties. Despite possessing strong anti-cancer properties, their systemic bioavailability is low. Therefore, both genistein and delphinidin, when used in combination with alternariol $(\mathrm{AOH})$ which is predominantly found in mushrooms, strongly interact with cancer cells. This combination demonstrated strong interactions with the HT-29 colon carcinoma cells and by influencing topoisomerase poisoning and reactive oxygen species (ROS) which are oxygen-containing chemical species [310]. Erlotinib, a cytostatic drug, is a chemotherapeutic drug for the treatment of pancreatic cancer and non-small cell lung cancer. The drug mainly functions by inhibition of epidermal growth factors (EGFR). Recently, a study was performed on human epithelial A431 cells with a combination of genistein and erlotinib. Genistein antagonized the Erlotinib-EGFR inhibitory effect, thereby effecting a different mechanism of cancer cell intrusion [311]. Another study demonstrated the combinatorial effect of genistein with sulforaphane on breast cancer MCF-7 and MDA-MB-231 cells. This combination resulted in an overall decrease in cell viability in both breast cancer cell lines thereby promoting cell death and cell cycle arrest in G1 phase (MCF-7 cells) and G2/M phase (MDA-MB-231 cells) [312]. A study in genistein-treated breast cancer MCF-7, and T47D cell lines also demonstrated the synergistic effect of genistein with cisplatin, paclitaxel, and tamoxifen chemotherapeutic drugs. As a result, in MCF-7 breast cancer cell lines, it was found that genistein + cisplatin and genistein + tamoxifen decreased the production of ROS and autophagy. Also, it enhanced the cell cycle at G2/M phase and decreased the cell cycle at the $G_{0} / G_{1}$ phase. On the contrary, this combination demonstrated a decrease in cell viability in T47D cell lines due to enhanced autophagic effect. Moreover, the genistein + tamoxifen combination led to an increase in cell viability in MCF-7 cell lines to a larger extent compared to genistein + paclitaxel combination [313].

Genistein also demonstrated synergistic action with resveratrol in the suppression of prostate cancer in the SV-40 Tag rat model. When this combination was fed to rats (high dose combination: $250 \mathrm{mg} / \mathrm{kg}$ AIN-76A diet and low dose combination: $83 \mathrm{mg}$ genistein $+83 \mathrm{mg}$ resveratrol/kg diet), 
there was a reduction in cell proliferation and reduced expression of insulin-like growth factor (IGF-1 factor) [314]. Many studies have shed light upon the poor bioavailability of genistein, quercetin, and biochanin A since their anti-cancerous activity such as tyrosine kinase activity, is hindered. A combinatorial approach can potentially overcome these programmed barriers. Prostate cancer LNCaP, DU-14, and PC-3 cells were subjected to treatment with genistein, quercetin and biochanin A. As a result, this combination demonstrated the inhibitory effect of tyrosine kinases, and also activated human aryl-hydrocarbon $(\mathrm{ArH})$ receptors thereby inhibiting prostate carcinogenesis [315]. A combination treatment of genistein, quercetin, and EGCG was performed on prostate cancer CWR22Rv1 cells. Even though each of these polyphenols possesses non-overlapping activities, their combination led to the suppression of cell proliferation thereby altering the expression of androgen receptor, tumor suppressor p53 and quinone reductase type 1(NQO1) enzyme [316].

\subsection{Combinatorial Effect of Resveratrol with Other Polyphenols and Anti-Cancer Drugs}

Resveratrol is a phytoalexin that can potentially counteract with many anti-cancerous properties. Due to its limited bioavailability, it can have hindrance in various molecular mechanisms associated with cancer. Studies have shown that resveratrol can overcome its bioavailability barriers when used in combination with other polyphenols and anti-cancer drugs. A study was conducted in breast cancer cell lines with the administration of a combination of resveratrol and thymoquinone. Thymoquinone is a phytochemical compound that possesses a large number of antioxidants, anti-inflammatory, anti-carcinogenic and chemo-sensitizing properties. In vivo, Balb/C mice were treated with resveratrol and thymoquinone, and as a result, there was an order of decrease in tumor size, followed by an increase in apoptosis, decrease in VEGF expression and inhibition of angiogenesis [317]. A study was conducted in prostate cancer cells, both in vitro and in vivo. Each of these polyphenols was administered alone or in combination in 22Rv1, DU145, and PC 3 cell lines and in a TRAMP mice model. When resveratrol was combined with quercetin, the bioavailability of resveratrol was heightened by constraining its sulfation, thereby imparting higher anti-proliferation properties [318]. ADR is a hydrochloride salt, and a pegylated liposomal formulation. Numerous studies have shown that liposomal formulation is prone to increase the risk in cardiac events. Dexrazoxane, an FDA-approved drug, is effectively used to lessen ADR-induced cytotoxicity. However, the use of Dexrazoxane has led to interference with the efficacy with ADR, thereby increasing the risks of secondary tumors. Resveratrol, quercetin, curcumin, and ADR were administered alone and in combination in ovarian cancer ES2-Luc or A2780ADR cells which resulted in reducing ADR dozing via chemosensitization. This combination also resulted in tumor size reduction and enhanced apoptosis in ovarian cancer xenograft models [319].

Doxorubicin (DOX) is a chemotherapeutic drug which is primarily used against gastric cancer. Long-term exposure to doxorubicin in gastric cancer patients leads to the development of drug resistance and tumor regression. As a result, resveratrol reverses the Dox-resistance challenge by preventing EMT by controlling PTEN/Akt signaling pathways. A study was conducted in gastric cancer SGC $_{7901}$ and MGC803 cell lines. A DOX-resistance gastric cancer cell line was developed by using a DOX concentration gradient method in $\mathrm{SGC}_{7901}$ cells. When these cells lines were subjected to treatment of resveratrol (RES) and doxorubicin, there was an enhanced cell survival of SGC $_{7901}$ cells. A nude mice xenograft model was also used for the in vivo procedure where resveratrol and doxorubicin were administered alone and in combination. This combination enhanced the expression of caspase-9, increased the level of PTEN, TSC1, TSC2, and cleaved caspase-3 and reduced p-Akt, p-mTOR, and p70 S6K significantly [320]. A few other combinations of resveratrol have also been investigated using in vivo models for their chemopreventive effects. A study was conducted with the potential abilities of resveratrol along with quercetin, apigenin, baicalein, curcumin, genistein and EGCG in vitro as well as in vivo. The study revealed that the combination of four out of six compounds: genistein, curcumin, EGCG, and resveratrol combination inhibited hedgehog signaling. Furthermore, the combination of apigenin, baicalein, and quercetin led to an overall decrease in GLi1 mRNA activity. When these compounds were fed in combination altogether, then there was an overall decrease in tumor 
size [321]. Gefitinib is a tyrosine kinase inhibitor (TKI) which interrupts signaling through various epidermal growth factors (EGFR) in target cells. A large number of clinical trials have demonstrated the potential benefits of gefitinib; however, like other anti-cancer drugs, its acquired resistance is a recurrent problem. Therefore, a potential combinatorial approach of dietary-based polyphenols with gefitinib might help to overcome the drug resistance. A combination study on grapes-based dietary polyphenols was conducted in vitro in breast cancer MDA-MB-231 cells as well as in vivo in a nude mice model. In vitro, the study revealed that resveratrol, quercetin, and catechin reduced Akt activity, induced the activation of AMPK, and inhibited mTOR signaling in breast cancer cell lines. Further, when resveratrol, quercetin and catechin were administered in combination with gefitinib, decreased gefitinib resistance occurred in these cell lines. In vivo, mice were fed with alone and in a combination $5 \mathrm{mg} / \mathrm{kg}$ of each resveratrol, quercetin, and catechin along with $200 \mathrm{mg} / \mathrm{kg}$ of gefitinib for 84 days. As a result, it was found that there was an inhibition of mammary tumor growth and metastasis to bone and liver in this mouse model [322]. A recent study was conducted in breast cancer patients wherein the patients were administered with a polyphenolic supplement consisting of a mixture of resveratrol $(53.85 \mathrm{mg}$ ) and various plant extracts (orange: $53.85 \mathrm{mg}$, lemon: $53.85 \mathrm{mg}$, pomegranate: $161.5 \mathrm{mg}$, cocoa: $161.5 \mathrm{mg}$, olive: $161.5 \mathrm{mg}$, and grape seed: $53.85 \mathrm{mg}$ ). The components were blended and further encapsulated in hard gelatin capsules. Each patient (19 patients) was administered with 3 capsules since the beginning of the diagnosis until the night before the surgery and urine samples, blood samples, normal tissue samples and malignant tissue samples were collected. Upon metabolic profiling, a total of 101 metabolites were identified in urine, 69 metabolites were identified in plasma, 39 metabolites were identified in normal tissue and 33 metabolites were identified in malignant tissues. As a result, the metabolites identified in malignant tissues did not exhibit anti-proliferative activity or estrogenic estrogenic/anti-esterogenic activities in MCF-7 breast cancer cells [323].

\subsection{Combinatorial Effect of Epigallocatechin Gallate (EGCG) with Other Polyphenols and Anti-Cancer Drugs}

Sunitinib is a small molecule tyrosine kinase inhibitor, which is mainly used for the treatment of renal and pancreatic cancer. Due to the long-term administration of sunitinib, cancer patients are likely to develop drug resistance. This can be overcome by using sunitinib in combination with EGCG. A study was conducted in H460, MCF-7 and H1975 cell lines in vitro and in a xenograft mice model for in vivo study. When sunitinib was administered in combination with EGCG, the EGCG was seen to chemically interact with sunitinib thereby reducing its plasma concentration, leading to inhibition of various receptor kinases and downstream kinases, such as Erk1/2, STAT3 and phosphoinositide 3-kinase (PI3K)/AKT [324]. Furthermore, a study was conducted when EGCG was used in combination with vitexin-2-O-xyloside and raphasatin in breast cancer MDA-MB-231 and MCF-7 cell lines, and colorectal Caco-2 and LoVo cell lines. Vitexin-2-Oxyloside was extracted and further purified from seeds of Beta vulgaris cicla, and glucoraphasatin from Raphanus sativus L. This combination induced apoptosis through the mitochondrial pathway. Further analysis also revealed cell cycle arrest at the G0/G1 phase. This combination also controlled the activity of Bax, Bcl2, caspase-9, and ADP-ribose polymerase [325]. Another study was conducted in vivo and in vitro in lung cancer H1299 cell lines and CL3 mice wherein $N$-acetylcysteine and EGCG were administered in combination and alone. EGCG inhibited CL13 cell growth when used alone. However, when $N$-acetylcysteine $(2 \mathrm{nM})$ was used in combination with EGCG, there was enhanced cell growth inhibition. This combination also increased ROS production and enhanced apoptotic activity [326].

The synergistic action of ECGC and pterostilbene in pancreatic cancer MIA PaCa- 2 and PANC- 1 cell lines was also revealed when administered in combination. In MIA PaCa-2 cells, this combination led to cell cycle arrest in S-phase arrest but not in PANC-1 cells. The combination also led to depolarization of mitochondria and upregulation of cytochrome- $\mathrm{C}$ in MIA PaCa-2 cells and not in PANC-1 cells. However, the increased apoptotic effect was observed in PANC-1 cells and not in MIA PaCa- 2 cells. Therefore, this combination results in enhanced anti-cancerous activities of EGCG and pterostilbene when used in combination with each other [327]. In vitro study was conducted in pancreatic cancer 
MIA PaCa-2 cell lines. The study demonstrated the effect of EGCG and tumor necrosis factor-related apoptosis-inducing ligand (TRAIL) together on pancreatic cancer cells. This combination resulted in the reduction of cell proliferation, enhanced apoptosis and enhanced activation of caspase- 8 activity. Hence, this combination could potentially serve as a potential therapeutic method for pancreatic cancer [328]. To further overcome the poor bioavailability of EGCG, another study was conducted in colorectal cancer in vivo and in vitro. Colorectal cancer HCT116 and SW480 cell lines were used, and cytotoxicity of both the compounds was measured individually and in combination. The study revealed that this combination of compounds led to minor enhancement in cytotoxicity. EGCG also induced enhanced apoptosis and cycle arrest in 5-fluorouracil-resistant colorectal cancer cells [329].

\subsection{Combinatorial Effect of Sulforaphane with Other Polyphenols and Anti-Cancer Drugs}

A large number of studies have demonstrated the synergistic effect of sulforaphane and green tea polyphenols (GTPs) in reactivating ER $\alpha$ expression in breast cancer MDA-MB-231 cell lines. A study was conducted in breast cancer MDA-MB-231 cell lines to investigate the consequence of ER $\alpha$ expression by reactivation of tumor suppressor genes (TSGs). The combination of sulforaphane and green tea polyphenols (GTPs) induced cell cycle arrest at G2/M phase by down-regulation of cell cycle regulatory proteins such as $\mathrm{p} 21^{\mathrm{CIP} 1 / \mathrm{WAF} 1}$ and KLOTHO that are mainly responsible for cell proliferation. Overall, this combination can induce the silencing of TSGs along with reactivation of $\mathrm{ER} \alpha$ in MDA-MB-231 cell lines [330]. Withaferin A is isolated from winter cherry which is commonly found in India. A large number of studies have demonstrated the anti-cancerous effect of withaferin A which leads to reduced cell proliferation and cell viability in various cancer cell lines. A study was conducted in breast cancer MCF-7 and MDA-MB-231 cell lines to investigate the combinatorial impact of sulforaphane and withaferin $A$ with their promising role in epigenetic gene expression of DNMT1, DNMT3A, DNMT3B, and HDAC1. It was detected that the combination had a synergistic effect on MCF-7 cells and an additive effect was observed on MDA-MB-231 cell lines thereby resulting in promotion of cell death as well as changes in BAX and BCL-2 activity. The combination also decreased HDAC expression and led to changes in DNMT1, DNMT3, and DNMT3B expression. The expression of DNMT1, DNMT3a, and DNMT3B was expressively reduced in MCF-7 and MDA-MB-231 cell lines [331]. The dietary polyphenols sulforaphane (SFN) and curcumin (CUR) have revealed tremendous chemopreventive effects in vivo and in vitro. However, the effects of these polyphenols are enhanced in different ways when used in combination. A study was conducted to investigate the combinatorial effect of SFN and CUR in a dose-dependent manner in liver cancer Hep-G2-C8 cell lines. Low doses of SFN; CUR; SFN + CUR enhanced the expression of HO-1 and UGT1A1 genes. Furthermore, higher dosage administration of SFN; CUR; SFN + CUR led to inhibition of cell viability [332].

Similar to other combinatorial approaches of polyphenols, EGCG has also demonstrated potential synergistic effects when administered along with SFN in vivo and in vitro in prostate cancer PC-3-AP-1 cell lines, ovarian cancer SKOV-ip1 and SKOVTR-ip2 cell lines and colon cancer HT-29-AP-1 cell lines. In prostate cancer, this combination resulted in down-regulation of the Nrf2, ATF, and ELK-1 genes. The combination also inhibited SRF expression and CREB5 compared to individual dietary agents and caused the inhibition of SFN-induced expression of the SLCO1B3 gene. In ovarian cancer, the combination of SFN and EGCG was administered in paclitaxel-sensitive SKOV-ip1 and paclitaxel-resistant SKOVTR-ip2 cell lines. This led to enhanced apoptosis in paclitaxel-resistant cells, increased expression of hTERT and DNMT1 in SKOVTR-ip2 cell lines and inhibition of cell viability in both the cell lines. In colon cancer HT-29 cell lines, low dose combination of SFN and EGCG enhanced AP-1 activity and decreased cell viability to $70 \%$. And higher dose combination of SFN and EGCG decreased cell viability to 40\% [333-335]. Many studies have demonstrated the anti-cancerous effects such as apoptosis and reduced tumor growth of acetazolamide (AZ) when used alone. The potential anti-cancerous properties of sulforaphane and $A Z$ can be enhanced when used in combination. A study investigated the synergistic action of sulforaphane and AZ alone and in 
combination in a dose-dependent manner which led to the suppression of tumor growth, enhanced apoptosis and activation of caspase- 3 and PARP activity. Furthermore, this combination also led to a significant effect on Ki-67, pHH3, cyclin D1 and down-regulation of p21 and p27 expression [336].

Another study demonstrated the combinatorial effect of sulforaphane, docetaxel, and paclitaxel in breast cancer SUM149 and SUM159 cell lines. Docetaxel and paclitaxel led to an increase in IL-6 and IL-8 secretion, and SFN caused a decrease in IL-6 and IL-8 secretion. However, when SFN was used in combination with docetaxel and paclitaxel, it was found that the IC50 of docetaxel and paclitaxel was reduced to $1.4 \mathrm{nM}$ and $2.2 \mathrm{nM}$ in SUM149 cells and $1.9 \mathrm{nM}$ and 7.5nM in SUM149 cells. Therefore, this combination can potentially inhibit cell proliferation. An in vivo study was also performed to investigate the combined effect of SFN and docetaxel in a xenograft mouse model. As a result, the frequency of tumor formation was lower in combination when compared to SFN and docetaxel alone. Furthermore, the administration of SFN also reversed the enrichment of aldehyde dehydrogenase and reduced the size of mammosphere formation, which is caused by docetaxel and paclitaxel [337].

\section{Conclusions}

Traditional therapies such as chemotherapy and radiation are associated with substantial side effects. Therefore, it is imperative to develop novel approaches that have fewer side effects and are safer. A plethora of in vivo studies have demonstrated the use of dietary-based polyphenols in cancer prevention and therapy. Despite a limited number of in vitro studies and clinical trials showing the use of these polyphenols in cancer prevention and therapeutic measures against various molecular mechanisms and epigenetic modifications, these compounds portray a promising role in cancer prevention and therapy if used safely. Besides their promising roles in cancer treatment, polyphenols may possess a poor bioavailability when administered alone. However, the bioavailability and multiple preventive properties of these nutrients can be improved when administered in combination with other polyphenols, phytochemicals, and anti-cancer drugs. Therefore, future research directions can potentially expand upon the use of dietary-based polyphenols, especially in combinations, as a potent and effective method in cancer prevention and therapy.

Author Contributions: I.A. conceived of the review paper with the guidance of T.O.T. The manuscript was drafted and edited by I.A., M.S. and T.O.T. All authors approved of the final manuscript to be published.

Funding: This work was supported in part by grants from the National Institute of Health (NCI R01CA178441 and NCI R01CA204346).

Conflicts of Interest: The authors declare no conflicts of interest.

$\begin{array}{ll}\text { Abbreviations } \\ \text { AOH } & \text { Alternariol } \\ \text { AZ } & \text { Acetazolamide } \\ \text { Bp } & \text { Base pair } \\ \text { CUR } & \text { Curcumin } \\ \text { DMH } & \text { 1, 2-dimethylhydrazine } \\ \text { DOX } & \text { Doxorubicin } \\ \text { DNMTs } & \text { DNA methyltransferases } \\ \text { DNMT1 } & \text { DNA methyltransferase 1 } \\ \text { DNMT3a } & \text { DNA methyltransferase 3 Alpha } \\ \text { DNMT3b } & \text { DNA methyltransferase 3 Beta } \\ \text { EGFR } & \text { Epidermal growth factors } \\ \text { EGCG } & \text { Epigallocatechin-3-gallate } \\ \text { GTPs } & \text { Green tea polyphenols } \\ \text { HAT } & \text { Histone acetyltransferase } \\ \text { HDAC } & \text { Histone deacetylase } \\ \text { HMT } & \text { Histone methyltransferase }\end{array}$




$\begin{array}{ll}\text { HDM } & \text { Histone demethylase } \\ \text { H3-K27 } & \text { Histone H3 on lysine 27 } \\ \text { H3-K9 } & \text { Histone H3 on lysine } 9 \\ \text { IFN } \gamma & \text { Interferon } \gamma \\ \text { miRNA } & \text { microRNA } \\ \text { NSCLC } & \text { Non-small cell lung cancer } \\ \text { PI } & \text { Proliferation index } \\ \text { PRSE } & \text { Polyphenol- rich Strawberry extract } \\ \text { ROS } & \text { Reactive oxygen species } \\ \text { SAM } & \text { S-adenosyl-L-methionine } \\ \text { SNP } & \text { Single Nucleotide Polymorphism } \\ \text { SFN } & \text { Sulforaphane } \\ \text { miRNAs } & \text { microRNAs } \\ \text { NAC } & \text { N-acetylcysteine } \\ \text { NQO1 } & \text { Quinone reductase type 1 } \\ \text { PTMs } & \text { Post-translational modifications } \\ \text { TSGs } & \text { Tumor suppressor genes } \\ \text { TRAIL } & \text { Tumor necrosis factor genes } \\ \text { YMAC } & \text { Young adult mouse colonocytes cells }\end{array}$

\section{References}

1. Siegel, R.L.; Miller, K.D.; Jemal, A. Cancer statistics, 2019. Cancer J. Clin. 2019, 69, 7-34. [CrossRef] [PubMed]

2. Seyfried, T.N.; Huysentruyt, L.C. On the origin of cancer metastasis. Crit. Rev. Oncog. 2013, 18, 43. [CrossRef] [PubMed]

3. Siegel, R.L.; Miller, K.D.; Jemal, A. Cancer statistics, 2019. CA, 2019; 69, 7-43.

4. Bray, F.; Ferlay, J.; Soerjomataram, I.; Siegel, R.L.; Torre, L.A.; Jemal, A. Global cancer statistics 2018: GLOBOCAN estimates of incidence and mortality worldwide for 36 cancers in 185 countries. Cancer J. Clin. 2018, 68, 394-424. [CrossRef] [PubMed]

5. Ferlay, J.; Shin, H.R.; Bray, F.; Forman, D.; Mathers, C.; Parkin, D.M. Estimates of worldwide burden of cancer in 2008: GLOBOCAN 2008. Int. J. Cancer 2010, 127, 2893-2917. [CrossRef] [PubMed]

6. Chaffer, C.L.; Weinberg, R.A. A perspective on cancer cell metastasis. Science 2011, 331, 1559-1564. [CrossRef] [PubMed]

7. Jochem, C.; Wallmann-Sperlich, B.; Leitzmann, M.F. The Influence of Sedentary Behavior on Cancer Risk: Epidemiologic Evidence and Potential Molecular Mechanisms. Curr. Nutr. Rep. 2019, 1-8. [CrossRef] [PubMed]

8. Wu, S.; Powers, S.; Zhu, W.; Hannun, Y.A. Substantial contribution of extrinsic risk factors to cancer development. Nature 2016, 529, 43. [CrossRef] [PubMed]

9. Zitvogel, L.; Pietrocola, F.; Kroemer, G. Nutrition, inflammation and cancer. Nat. Immunol. 2017, $18,843$. [CrossRef] [PubMed]

10. Sever, R.; Brugge, J.S. Signal transduction in cancer. Cold Spring Harb. Perspect. Med. 2015, 5, a006098. [CrossRef]

11. Basak, P.; Sadhukhan, P.; Sarkar, P.; Sil, P.C. Perspectives of the Nrf-2 signaling pathway in cancer progression and therapy. Toxicol. Rep. 2017, 4, 306-318. [CrossRef] [PubMed]

12. Fallah, Y.; Brundage, J.; Allegakoen, P.; Shajahan-Haq, A.N. MYC-driven pathways in breast cancer subtypes. Biomolecules 2017, 7, 53. [CrossRef] [PubMed]

13. Fruman, D.A.; Chiu, H.; Hopkins, B.D.; Bagrodia, S.; Cantley, L.C.; Abraham, R.T. The PI3K pathway in human disease. Cell 2017, 170, 605-635. [CrossRef] [PubMed]

14. Joerger, A.C.; Fersht, A.R. The p53 pathway: origins, inactivation in cancer, and emerging therapeutic approaches. Annu. Rev. Biochem. 2016, 85, 375-404. [CrossRef] [PubMed]

15. Otto, T.; Sicinski, P. Cell cycle proteins as promising targets in cancer therapy. Nat. Rev. Cancer 2017, 17, 93. [CrossRef] [PubMed]

16. Simón-Carrasco, L.; Jiménez, G.; Barbacid, M.; Drosten, M. The Capicua tumor suppressor: a gatekeeper of Ras signaling in development and cancer. Cell Cycle 2018, 17, 702-711. [CrossRef] 
17. Esteller, M. Epigenetics in cancer. New Engl. J. Med. 2008, 358, 1148-1159. [CrossRef] [PubMed]

18. Aggarwal, R.; Jha, M.; Shrivastava, A.; Jha, A.K. Natural compounds: role in reversal of epigenetic changes. Biochemistry 2015, 80, 972-989. [CrossRef]

19. Audia, J.E.; Campbell, R.M. Histone modifications and cancer. Cold Spring Harb. Perspect. Biol. 2016, 8, a019521. [CrossRef]

20. Berghe, W.V.; Ndlovu, M.N.; Hoya-Arias, R.; Dijsselbloem, N.; Gerlo, S.; Haegeman, G. Keeping up NF-кB appearances: Epigenetic control of immunity or inflammation-triggered epigenetics. Biochem. Pharmacol. 2006, 72, 1114-1131. [CrossRef]

21. Lee, B.M.; Mahadevan, L.C. Stability of histone modifications across mammalian genomes: implications for 'epigenetic'marking. J. Cell. Biochem. 2009, 108, 22-34. [CrossRef]

22. Lin, S.; Gregory, R.I. MicroRNA biogenesis pathways in cancer. Nat. Rev. Cancer 2015, 15, 321. [CrossRef] [PubMed]

23. Moolgavkar, S.H.; Knudson, A.G. Mutation and cancer: a model for human carcinogenesis. Jnci: J. Natl. Cancer Inst. 1981, 66, 1037-1052. [CrossRef] [PubMed]

24. Sager, R. Expression genetics in cancer: shifting the focus from DNA to RNA. Proc. Natl. Acad. Sci. USA 1997, 94, 952-955. [CrossRef] [PubMed]

25. Hellebrekers, D.M.; Griffioen, A.W.; van Engeland, M. Dual targeting of epigenetic therapy in cancer. Biochim. Et Biophys. Acta (Bba)-Rev. Cancer 2007, 1775, 76-91. [CrossRef] [PubMed]

26. Berghe, W.V. Epigenetic impact of dietary polyphenols in cancer chemoprevention: lifelong remodeling of our epigenomes. Pharmacol. Res. 2012, 65, 565-576. [CrossRef]

27. Li, X.; Oprea-Ilies, G.M.; Krishnamurti, U. New developments in breast cancer and their impact on daily practice in pathology. Arch. Pathol. Lab. Med. 2017, 141, 490-498. [CrossRef]

28. Kawada, M.; Atsumi, S.; Wada, S.-I.; Sakamoto, S. Novel approaches for identification of anti-tumor drugs and new bioactive compounds. J. Antibiot. 2018, 71,39. [CrossRef]

29. Ruiz-Torres, V.; Encinar, J.; Herranz-López, M.; Pérez-Sánchez, A.; Galiano, V.; Barrajón-Catalán, E.; Micol, V. An updated review on marine anticancer compounds: The use of virtual screening for the discovery of small-molecule cancer drugs. Molecules 2017, 22, 1037. [CrossRef]

30. Chun, S.; Cha, B.; Ko, K.; Ryu, A.; Kim, Y.; Kim, S. PO227 gender differences of diabetic peripheral neuropathy in korea. Diabetes Res. Clin. Pract. 2014, 106, S164-S165. [CrossRef]

31. Jagtap, S.; Meganathan, K.; Wagh, V.; Winkler, J.; Hescheler, J.; Sachinidis, A. Chemoprotective mechanism of the natural compounds, epigallocatechin-3-O-gallate, quercetin and curcumin against cancer and cardiovascular diseases. Curr. Med. Chem. 2009, 16, 1451-1462. [CrossRef]

32. Pan, M.H.; Lai, C.S.; Tsai, M.L.; Ho, C.T. Chemoprevention of nonalcoholic fatty liver disease by dietary natural compounds. Mol. Nutr. Food Res. 2014, 58, 147-171. [CrossRef] [PubMed]

33. Chen, S. Natural products triggering biological targets-a review of the anti-inflammatory phytochemicals targeting the arachidonic acid pathway in allergy asthma and rheumatoid arthritis. Curr. Drug Targets 2011, 12, 288-301. [CrossRef] [PubMed]

34. Albarracin, S.L.; Stab, B.; Casas, Z.; Sutachan, J.J.; Samudio, I.; Gonzalez, J.; Gonzalo, L.; Capani, F.; Morales, L.; Barreto, G.E. Effects of natural antioxidants in neurodegenerative disease. Nutr. Neurosci. 2012, 15, 1-9. [CrossRef]

35. An, J.; Yang, H.; Zhang, Q.; Liu, C.; Zhao, J.; Zhang, L.; Chen, B. Natural products for treatment of osteoporosis: The effects and mechanisms on promoting osteoblast-mediated bone formation. Life Sci. 2016, 147, 46-58. [CrossRef] [PubMed]

36. Huang, W.-Y.; Cai, Y.-Z.; Zhang, Y. Natural phenolic compounds from medicinal herbs and dietary plants: potential use for cancer prevention. Nutr. Cancer 2009, 62, 1-20. [CrossRef] [PubMed]

37. Gericke, N.P.; Van Wyk, B.-E. Pharmaceutical compositions containing mesembrine and related compounds. Google Patents WO1997046234A1, 2001.

38. Grienke, U.; Schmidtke, M.; von Grafenstein, S.; Kirchmair, J.; Liedl, K.R.; Rollinger, J.M. Influenza neuraminidase: a druggable target for natural products. Nat. Prod. Rep. 2012, 29, 11-36. [CrossRef] [PubMed]

39. Carocho, M.; Ferreira, I.C. A review on antioxidants, prooxidants and related controversy: natural and synthetic compounds, screening and analysis methodologies and future perspectives. Food Chem. Toxicol. 2013, 51, 15-25. [CrossRef] [PubMed] 
40. Maqbool, F.; Mostafalou, S.; Bahadar, H.; Abdollahi, M. Review of endocrine disorders associated with environmental toxicants and possible involved mechanisms. Life Sci. 2016, 145, 265-273. [CrossRef] [PubMed]

41. Tőzsér, J.; Benkő, S. Natural compounds as regulators of NLRP3 inflammasome-mediated IL-1 $\beta$ production. Mediat. Inflamm. 2016, 2016, 5460302. [CrossRef]

42. Souza, A.B.; De Souza, M.G.; Moreira, M.A.; Moreira, M.R.; Furtado, N.A.; Martins, C.H.; Bastos, J.K.; Santos, R.A.; Heleno, V.C.; Ambrosio, S.R. Antimicrobial evaluation of diterpenes from Copaifera langsdorffii oleoresin against periodontal anaerobic bacteria. Molecules 2011, 16, 9611-9619. [CrossRef] [PubMed]

43. Balasuriya, B.N.; Rupasinghe, H.V. Plant flavonoids as angiotensin converting enzyme inhibitors in regulation of hypertension. Funct. Foods Health Dis. 2011, 1, 172-188.

44. Działo, M.; Mierziak, J.; Korzun, U.; Preisner, M.; Szopa, J.; Kulma, A. The potential of plant phenolics in prevention and therapy of skin disorders. Int. J. Mol. Sci. 2016, 17, 160. [CrossRef] [PubMed]

45. Puertollano, M.; Puertollano, E.; Alvarez de Cienfuegos, G. Dietary antioxidants: immunity and host defense. Curr. Top. Med. Chem. 2011, 11, 1752-1766. [CrossRef] [PubMed]

46. Jakobek, L. Interactions of polyphenols with carbohydrates, lipids and proteins. Food Chem. 2015, 175, 556-567. [CrossRef] [PubMed]

47. Ramos, S. Cancer chemoprevention and chemotherapy: dietary polyphenols and signalling pathways. Mol. Nutr. Food Res. 2008, 52, 507-526. [CrossRef]

48. Sun, X.; Lin, D.; Wu, W.; Lv, Z. Translational Chinese medicine: A way for development of Traditional Chinese Medicine. Chin. Med. 2011, 2, 186. [CrossRef]

49. Meeran, S.M.; Ahmed, A.; Tollefsbol, T.O. Epigenetic targets of bioactive dietary components for cancer prevention and therapy. Clin. Epigenetics 2010, 1, 101. [CrossRef]

50. Fantini, M.; Benvenuto, M.; Masuelli, L.; Frajese, G.; Tresoldi, I.; Modesti, A.; Bei, R. In vitro and in vivo antitumoral effects of combinations of polyphenols, or polyphenols and anticancer drugs: Perspectives on cancer treatment. Int. J. Mol. Sci. 2015, 16, 9236-9282. [CrossRef]

51. Scalbert, A.; Manach, C.; Morand, C.; Rémésy, C.; Jiménez, L. Dietary polyphenols and the prevention of diseases. Crit. Rev. Food Sci. Nutr. 2005, 45, 287-306. [CrossRef]

52. Tsao, R. Chemistry and biochemistry of dietary polyphenols. Nutrients 2010, 2, 1231-1246. [CrossRef]

53. Manach, C.; Scalbert, A.; Morand, C.; Rémésy, C.; Jiménez, L. Polyphenols: food sources and bioavailability. Am. J. Clin. Nutr. 2004, 79, 727-747. [CrossRef] [PubMed]

54. Yao, L.H.; Jiang, Y.; Shi, J.; Tomas-Barberan, F.; Datta, N.; Singanusong, R.; Chen, S. Flavonoids in food and their health benefits. Plant Foods Hum. Nutr. 2004, 59, 113-122. [CrossRef] [PubMed]

55. González-Vallinas, M.; González-Castejón, M.; Rodríguez-Casado, A.; Ramírez de Molina, A. Dietary phytochemicals in cancer prevention and therapy: A complementary approach with promising perspectives. Nutr. Rev. 2013, 71, 585-599. [CrossRef] [PubMed]

56. Beecher, G.R. Overview of dietary flavonoids: nomenclature, occurrence and intake. J. Nutr. 2003, 133, 3248S-3254S. [CrossRef] [PubMed]

57. Kao, Y.-H.; Hiipakka, R.A.; Liao, S. Modulation of endocrine systems and food intake by green tea epigallocatechin gallate. Endocrinology 2000, 141, 980-987. [CrossRef] [PubMed]

58. Sharma, R.A.; McLelland, H.R.; Hill, K.A.; Ireson, C.R.; Euden, S.A.; Manson, M.M.; Pirmohamed, M.; Marnett, L.J.; Gescher, A.J.; Steward, W.P. Pharmacodynamic and pharmacokinetic study of oral Curcuma extract in patients with colorectal cancer. Clin. Cancer Res. 2001, 7, 1894-1900. [PubMed]

59. Tang, S.-N.; Singh, C.; Nall, D.; Meeker, D.; Shankar, S.; Srivastava, R.K. The dietary bioflavonoid quercetin synergizes with epigallocathechin gallate (EGCG) to inhibit prostate cancer stem cell characteristics, invasion, migration and epithelial-mesenchymal transition. J. Mol. Signal. 2010, 5, 14. [CrossRef] [PubMed]

60. Havsteen, B.H. The biochemistry and medical significance of the flavonoids. Pharmacol. Ther. 2002, 96, 67-202. [CrossRef]

61. Crozier, A.; Jaganath, I.B.; Clifford, M.N. Dietary phenolics: chemistry, bioavailability and effects on health. Nat. Prod. Rep. 2009, 26, 1001-1043. [CrossRef] [PubMed]

62. Koo, J.; Cabarcas-Petroski, S.; Petrie, J.L.; Diette, N.; White, R.J.; Schramm, L. Induction of proto-oncogene BRF2 in breast cancer cells by the dietary soybean isoflavone daidzein. BMC Cancer 2015, 15, 905. [CrossRef]

63. Shukla, S.; Gupta, S. Apigenin: a promising molecule for cancer prevention. Pharm. Res. 2010, 27, 962-978. [CrossRef] [PubMed] 
64. Hollands, A.; Corriden, R.; Gysler, G.; Dahesh, S.; Olson, J.; Ali, S.R.; Kunkel, M.T.; Lin, A.E.; Forli, S.; Newton, A.C. Natural product anacardic acid from cashew nut shells stimulates neutrophil extracellular trap production and bactericidal activity. J. Biol. Chem. 2016, 291, 13964-13973. [CrossRef] [PubMed]

65. Moon, Y.J.; Shin, B.S.; An, G.; Morris, M.E. Biochanin A inhibits breast cancer tumor growth in a murine xenograft model. Pharm. Res. 2008, 25, 2158. [CrossRef] [PubMed]

66. Szliszka, E.; Czuba, Z.P.; Mertas, A.; Paradysz, A.; Krol, W. Urologic Oncology: Seminars and Original Investigations, 2013. In The Dietary Isoflavone Biochanin-A Sensitizes Prostate Cancer Cells to TRAIL-Induced Apoptosis; Elsevier: Katowice, Poland, 2013; Volume 31, pp. 331-342.

67. Ullah, M.F.; Shamim, U.; Hanif, S.; Azmi, A.S.; Hadi, S.M. Cellular DNA breakage by soy isoflavone genistein and its methylated structural analogue biochanin A. Mol. Nutr. Food Res. 2009, 53, 1376-1385. [CrossRef] [PubMed]

68. Cai, Y.; Luo, Q.; Sun, M.; Corke, H. Antioxidant activity and phenolic compounds of 112 traditional Chinese medicinal plants associated with anticancer. Life Sci. 2004, 74, 2157-2184. [CrossRef] [PubMed]

69. Cai, Y.-Z.; Sun, M.; Xing, J.; Luo, Q.; Corke, H. Structure-radical scavenging activity relationships of phenolic compounds from traditional Chinese medicinal plants. Life Sci. 2006, 78, 2872-2888. [CrossRef] [PubMed]

70. Clarke, K.A.; Dew, T.P.; Watson, R.E.; Farrar, M.D.; Osman, J.E.; Nicolaou, A.; Rhodes, L.E.; Williamson, G. Green tea catechins and their metabolites in human skin before and after exposure to ultraviolet radiation. J. Nutr. Biochem. 2016, 27, 203-210. [CrossRef] [PubMed]

71. Khoo, H.E.; Azlan, A.; Tang, S.T.; Lim, S.M. Anthocyanidins and anthocyanins: colored pigments as food, pharmaceutical ingredients, and the potential health benefits. Food Nutr. Res. 2017, 61, 1361779. [CrossRef]

72. Byun, S.-Y.; Kim, D.-B.; Kim, E. Curcumin ameliorates the tumor-enhancing effects of a high-protein diet in an azoxymethane-induced mouse model of colon carcinogenesis. Nutr. Res. 2015, 35, 726-735. [CrossRef]

73. Etherton, A.K.; Omaye, S.T. Oxidation of olive oil fortified with quercetin, caffeic acid, tyrosol and hydroxytyrosol. Nutr. Food Sci. 2015, 45, 493-508. [CrossRef]

74. Hmid, I.; Elothmani, D.; Hanine, H.; Oukabli, A.; Mehinagic, E. Comparative study of phenolic compounds and their antioxidant attributes of eighteen pomegranate (Punica granatum L.) cultivars grown in Morocco. Arab. J. Chem. 2017, 10, S2675-S2684. [CrossRef]

75. Hsia, S.-M.; Lee, W.-H.; Yen, G.-C.; Wu, C.-H. Capsaicin, an active ingredient from chilli peppers, attenuates glycative stress and restores sRAGE levels in diabetic rats. J. Funct. Foods 2016, 21, 406-417. [CrossRef]

76. Barnes, S.; Prasain, J.; D'Alessandro, T.; Arabshahi, A.; Botting, N.; Lila, M.A.; Jackson, G.; Janle, E.M.; Weaver, C.M. The metabolism and analysis of isoflavones and other dietary polyphenols in foods and biological systems. Food Funct. 2011, 2, 235-244. [CrossRef] [PubMed]

77. Zhang, Y.; Wang, G.-J.; Song, T.T.; Murphy, P.A.; Hendrich, S. Urinary disposition of the soybean isoflavones daidzein, genistein and glycitein differs among humans with moderate fecal isoflavone degradation activity. J. Nutr. 1999, 129, 957-962. [CrossRef] [PubMed]

78. Diniz, C.; Suliburska, J.; Ferreira, I.M. New insights into the antiangiogenic and proangiogenic properties of dietary polyphenols. Mol. Nutr. Food Res. 2017, 61, 1600912. [CrossRef]

79. Polissiou, M.; Daferera, D. Major Dietary Antioxidants and Their Food Sources. In Antioxidants in Health and Disease; CRC Press: Boca Raton, FL, USA, 2015; pp. 42-63.

80. González-Sarrías, A.; García-Villalba, R.; Núñez-Sánchez, M.Á.; Tomé-Carneiro, J.; Zafrilla, P.; Mulero, J.; Tomás-Barberán, F.A.; Espín, J.C. Identifying the limits for ellagic acid bioavailability: A crossover pharmacokinetic study in healthy volunteers after consumption of pomegranate extracts. J. Funct. Foods 2015, 19, 225-235. [CrossRef]

81. Gadkari, P.V.; Balaraman, M. Catechins: Sources, extraction and encapsulation: A review. Food Bioprod. Process. 2015, 93, 122-138. [CrossRef]

82. Yang, X.; Tomás-Barberán, F.A. Tea is a significant dietary source of ellagitannins and ellagic acid. J. Agric. Food Chem. 2019, 67, 5394-5404. [CrossRef]

83. Krenn, L.; Unterrieder, I.; Ruprechter, R. Quantification of isoflavones in red clover by high-performance liquid chromatography. J. Chromatogr. B 2002, 777, 123-128. [CrossRef]

84. Umphress, S.T.; Murphy, S.P.; Franke, A.A.; Custer, L.J.; Blitz, C.L. Isoflavone content of foods with soy additives. J. Food Compos. Anal. 2005, 18, 533-550. [CrossRef] 
85. Remsberg, C.M.; Martinez, S.E.; Akinwumi, B.C.; Anderson, H.D.; Takemoto, J.K.; Sayre, C.L.; Davies, N.M. Preclinical pharmacokinetics and pharmacodynamics and content analysis of gnetol in foodstuffs. Phytother. Res. 2015, 29, 1168-1179. [CrossRef] [PubMed]

86. Simitzis, P.; Charismiadou, M.; Goliomytis, M.; Charalambous, A.; Detska, I.; Deligeorgis, S. The effects of dietary hesperidin and naringin supplementation on lamb performance and meat characteristics. Animal Sci. J. 2016. [CrossRef]

87. Lee, Y.-I.; Lee, Y.; Kim, H.; Ramalingam, M. Phytochemical and pharmacological role of liquiritigenin and isoliquiritigenin from Radix Glycyrrhizae in human health and disease models. Front. Aging Neurosci. 2018, 10,348 .

88. Venturelli, S.; Leischner, C.; Burkard, M. Natural Polyphenol Kaempferol and Its Epigenetic Impact on Histone Deacetylases: Focus on Human Liver Cells. Handb. Nutr. Dietand Epigenetics 2017, 1-17.

89. Gonçalves, S.; Romano, A. Inhibitory properties of phenolic compounds against enzymes linked with human diseases. In Phenolic Compounds. Biological Activity; Soto-Hernández, M., Palma-Tenango, M., García-Mateos, M.R., Eds.; InTech: London, UK, 2017; pp. 99-118.

90. López-Lázaro, M. Distribution and biological activities of the flavonoid luteolin. Mini Rev. Med. Chem. 2009, 9, 31-59. [CrossRef] [PubMed]

91. Shimoi, K.; Okada, H.; Furugori, M.; Goda, T.; Takase, S.; Suzuki, M.; Hara, Y.; Yamamoto, H.; Kinae, N. Intestinal absorption of luteolin and luteolin 7-O- $\beta$-glucoside in rats and humans. Febs Lett. 1998, 438, 220-224. [CrossRef]

92. Khan, M.T.H.; Orhan, I.; Şenol, F.; Kartal, M.; Şener, B.; Dvorská, M.; Šmejkal, K.; Šlapetová, T. Cholinesterase inhibitory activities of some flavonoid derivatives and chosen xanthone and their molecular docking studies. Chem. -Biol. Interact. 2009, 181, 383-389. [CrossRef] [PubMed]

93. Bresciani, L.; Calani, L.; Cossu, M.; Mena, P.; Sayegh, M.; Ray, S.; Del Rio, D. (Poly) phenolic characterization of three food supplements containing 36 different fruits, vegetables and berries. PharmaNutrition 2015, 3, 11-19. [CrossRef]

94. Felgines, C.; Texier, O.; Morand, C.; Manach, C.; Scalbert, A.; Régerat, F.; Rémésy, C. Bioavailability of the flavanone naringenin and its glycosides in rats. Am. J. Physiol. -Gastrointest. Liver Physiol. 2000, 279, G1148-G1154. [CrossRef] [PubMed]

95. Chen, W.; Yeo, S.C.M.; Elhennawy, M.G.A.A.; Lin, H.-S. Oxyresveratrol: A bioavailable dietary polyphenol. J. Funct. Foods 2016, 22, 122-131. [CrossRef]

96. Truong, V.-D.; Deighton, N.; Thompson, R.T.; McFeeters, R.F.; Dean, L.O.; Pecota, K.V.; Yencho, G.C. Characterization of anthocyanins and anthocyanidins in purple-fleshed sweetpotatoes by HPLC-DAD/ESI-MS/MS. J. Agric. Food Chem. 2009, 58, 404-410. [CrossRef] [PubMed]

97. Kershaw, J.; Kim, K.-H. The therapeutic potential of piceatannol, a natural stilbene, in metabolic diseases: a review. J. Med. Food 2017, 20, 427-438. [CrossRef] [PubMed]

98. Tsai, H.-Y.; Ho, C.-T.; Chen, Y.-K. Biological actions and molecular effects of resveratrol, pterostilbene, and 3'-hydroxypterostilbene. J. Food Drug Anal. 2017, 25, 134-147. [CrossRef] [PubMed]

99. Hertog, M.G.; Hollman, P.C.; Van de Putte, B. Content of potentially anticarcinogenic flavonoids of tea infusions, wines, and fruit juices. J. Agric. Food Chem. 1993, 41, 1242-1246. [CrossRef]

100. Justesen, U.; Knuthsen, P. Composition of flavonoids in fresh herbs and calculation of flavonoid intake by use of herbs in traditional Danish dishes. Food Chem. 2001, 73, 245-250. [CrossRef]

101. Vlavcheski, F.; Naimi, M.; Murphy, B.; Hudlicky, T.; Tsiani, E. Rosmarinic acid, a rosemary extract polyphenol, increases skeletal muscle cell glucose uptake and activates AMPK. Molecules 2017, 22, 1669. [CrossRef] [PubMed]

102. Atanassova, M.; Bagdassarian, V. Rutin content in plant products. J. Univ. Chem. Technol. Metall. 2009, 44, 201-203.

103. Chang, S.; Tan, C.; Frankel, E.N.; Barrett, D.M. Low-density lipoprotein antioxidant activity of phenolic compounds and polyphenol oxidase activity in selected clingstone peach cultivars. J. Agric. Food Chem. 2000, 48, 147-151. [CrossRef]

104. Gálvez, M.C.; Barroso, C.G.; Pérez-Bustamante, J.A. Analysis of polyphenolic compounds of different vinegar samples. Z. Für Lebensm. -Unters. Und Forsch. 1994, 199, 29-31. [CrossRef] 
105. Pereira, C.; Barros, L.; Alves, M.J.; Santos-Buelga, C.; Ferreira, I.C. Artichoke and milk thistle pills and syrups as sources of phenolic compounds with antimicrobial activity. Food Funct. 2016, 7, 3083-3090. [CrossRef] [PubMed]

106. Suvarna, V.; Chaubey, P.; Sangave, P.C.; Singh, A.K. An Insight of Polyphenols in Lung Cancer Chemoprevention. In Polyphenols: Prevention and Treatment of Human Disease; Elsevier: Amsterdam, The Netherlands, 2018; pp. 125-136.

107. Arivazhagan, L.; Subramanian, S.P. Tangeretin, a citrus flavonoid attenuates oxidative stress and protects hepatocellular architecture in rats with 7, 12-dimethylbenz (a) anthracene induced experimental mammary carcinoma. J. Funct. Foods 2015, 15, 339-353. [CrossRef]

108. Cerezo, A.B.; Tesfaye, W.; Soria-Díaz, M.; Torija, M.J.; Mateo, E.; Garcia-Parrilla, M.C.; Troncoso, A.M. Effect of wood on the phenolic profile and sensory properties of wine vinegars during ageing. J. Food Compos. Anal. 2010, 23, 175-184. [CrossRef]

109. Leung, L.K.; Su, Y.; Chen, R.; Zhang, Z.; Huang, Y.; Chen, Z.-Y. Theaflavins in black tea and catechins in green tea are equally effective antioxidants. J. Nutr. 2001, 131, 2248-2251. [CrossRef] [PubMed]

110. Alves, V.G.; Souza, A.G.; Chiavelli, L.U.; Ruiz, A.L.; Carvalho, J.E.; Pomini, A.M.; Silva, C.C. Phenolic compounds and anticancer activity of commercial sugarcane cultivated in Brazil. An. Da Acad. Bras. De Ciências 2016, 88, 1201-1209. [CrossRef] [PubMed]

111. Takahashi, K.; Osada, K. Effect of dietary purified xanthohumol from hop (Humulus lupulus L.) pomace on adipose tissue mass, fasting blood glucose level, and lipid metabolism in KK-Ay mice. J. Oleo Sci. 2017, 66, 531-541. [CrossRef] [PubMed]

112. Bhat, K.P.; Pezzuto, J.M. Cancer chemopreventive activity of resveratrol. Ann. N. Y. Acad. Sci. USA 2002, 957, 210-229. [CrossRef]

113. Lall, R.; Syed, D.; Adhami, V.; Khan, M.; Mukhtar, H. Dietary polyphenols in prevention and treatment of prostate cancer. Int. J. Mol. Sci. 2015, 16, 3350-3376. [CrossRef]

114. Yang, C.S.; Landau, J.M.; Huang, M.-T.; Newmark, H.L. Inhibition of carcinogenesis by dietary polyphenolic compounds. Annu. Rev. Nutr. 2001, 21,381-406. [CrossRef]

115. Scalbert, A.; Williamson, G. Dietary intake and bioavailability of polyphenols. J. Nutr. 2000, 130, 2073S-2085S. [CrossRef]

116. Bogaards, J.; Van Ommen, B.; Falke, H.; Willems, M.; Van Bladeren, P. Glutathione S-transferase subunit induction patterns of Brussels sprouts, allyl isothiocyanate and goitrin in rat liver and small intestinal mucosa: a new approach for the identification of inducing xenobiotics. Food Chem. Toxicol. 1990, 28, 81-88. [CrossRef]

117. Shaikh, J.; Ankola, D.; Beniwal, V.; Singh, D.; Kumar, M.R. Nanoparticle encapsulation improves oral bioavailability of curcumin by at least 9-fold when compared to curcumin administered with piperine as absorption enhancer. Eur. J. Pharm. Sci. 2009, 37, 223-230. [CrossRef] [PubMed]

118. Barras, A.; Mezzetti, A.; Richard, A.; Lazzaroni, S.; Roux, S.; Melnyk, P.; Betbeder, D.; Monfilliette-Dupont, N. Formulation and characterization of polyphenol-loaded lipid nanocapsules. Int. J. Pharm. 2009, 379, 270-277. [CrossRef] [PubMed]

119. Siddiqui, I.A.; Adhami, V.M.; Bharali, D.J.; Hafeez, B.B.; Asim, M.; Khwaja, S.I.; Ahmad, N.; Cui, H.; Mousa, S.A.; Mukhtar, H. Introducing nanochemoprevention as a novel approach for cancer control: proof of principle with green tea polyphenol epigallocatechin-3-gallate. Cancer Res. 2009, 69, 1712-1716. [CrossRef] [PubMed]

120. Zhou, X.J.; Hu, X.M.; Yi, Y.M.; Wan, J. Preparation and body distribution of freeze-dried powder of ursolic acid phospholipid nanoparticles. Drug Dev. Ind. Pharm. 2009, 35, 305-310. [CrossRef] [PubMed]

121. Williamson, G.; Manach, C. Bioavailability and bioefficacy of polyphenols in humans. II. Review of 93 intervention studies. Am. J. Clin. Nutr. 2005, 81, 243S-255S. [CrossRef] [PubMed]

122. Berdasco, M.; Esteller, M. Aberrant epigenetic landscape in cancer: how cellular identity goes awry. Dev. Cell 2010, 19, 698-711. [CrossRef] [PubMed]

123. Esteller, M. Aberrant DNA methylation as a cancer-inducing mechanism. Annu. Rev. Pharmacol. Toxicol. 2005, 45, 629-656. [CrossRef] [PubMed]

124. Zaidi, S.K.; Van Wijnen, A.J.; Lian, J.B.; Stein, J.L.; Stein, G.S. Targeting deregulated epigenetic control in cancer. J. Cell. Physiol. 2013, 228, 2103-2108. [CrossRef] [PubMed]

125. Asif, D.; Naveed, M.; Rashid, U. DNA Methylation in Cancer Tissues. J. Cell Sci. 2017, 8, 2. 
126. Goll, M.G.; Bestor, T.H. Eukaryotic cytosine methyltransferases. Annu. Rev. Biochem. 2005, 74, 481-514. [CrossRef]

127. Siedlecki, P.; Zielenkiewicz, P. Mammalian DNA methyltransferases. Acta Biochim. Pol. Engl. Ed. 2006, 53, 245.

128. Klutstein, M.; Nejman, D.; Greenfield, R.; Cedar, H. DNA methylation in cancer and aging. Cancer Res. 2016, 76, 3446-3450. [CrossRef] [PubMed]

129. Watanabe, Y.; Maekawa, M. Methylation of DNA in cancer. In Advances in Clinical Chemistry; Elsevier: Amsterdam, The Netherlands, 2010; Volume 52, pp. 145-167.

130. Drexler, H. Review of alterations of the cyclin-dependent kinase inhibitor INK 4 family genes p15, p16, p18 and p19 in human leukemia-lymphoma cells. Leukemia 1998, 12, 845. [CrossRef] [PubMed]

131. Das, P.M.; Singal, R. DNA methylation and cancer. J. Clin. Oncol. 2004, 22, 4632-4642. [CrossRef] [PubMed]

132. Akhavan-Niaki, H.; Samadani, A.A. DNA methylation and cancer development: molecular mechanism. Cell Biochem. Biophys. 2013, 67, 501-513. [CrossRef] [PubMed]

133. Carlos-Reyes, A.; López-González, J.S.; Meneses-Flores, M.; Gallardo-Rincón, D.; Ruíz-García, E.; Marchat, L.A.; Astudillo de la Vega, H.; Hernández de la Cruz, O.N.; López-Camarillo, C. Dietary Compounds as Epigenetic Modulating Agents in Cancer. Front. Genet. 2019, 10, 79. [CrossRef] [PubMed]

134. Jones, P.A.; Issa, J.-P.J.; Baylin, S. Targeting the cancer epigenome for therapy. Nat. Rev. Genet. 2016, 17, 630. [CrossRef]

135. Sato, T.; Issa, J.-P.J.; Kropf, P. DNA hypomethylating drugs in cancer therapy. Cold Spring Harb. Perspect. Med. 2017, 7, a026948. [CrossRef] [PubMed]

136. Xie, Q.; Bai, Q.; Zou, L.Y.; Zhang, Q.Y.; Zhou, Y.; Chang, H.; Yi, L.; Zhu, J.D.; Mi, M.T. Genistein inhibits DNA methylation and increases expression of tumor suppressor genes in human breast cancer cells. Geneschromosomes Cancer 2014, 53, 422-431. [CrossRef]

137. Kala, R.; Shah, H.N.; Martin, S.L.; Tollefsbol, T.O. Epigenetic-based combinatorial resveratrol and pterostilbene alters DNA damage response by affecting SIRT1 and DNMT enzyme expression, including SIRT1-dependent $\gamma-\mathrm{H} 2 \mathrm{AX}$ and telomerase regulation in triple-negative breast cancer. BMC Cancer 2015, 15, 672. [CrossRef]

138. Luger, K.; Mäder, A.W.; Richmond, R.K.; Sargent, D.F.; Richmond, T.J. Crystal structure of the nucleosome core particle at $2.8 \AA$ resolution. Nature 1997, 389, 251. [CrossRef] [PubMed]

139. Hergeth, S.P.; Schneider, R. The H1 linker histones: multifunctional proteins beyond the nucleosomal core particle. Embo Rep. 2015, 16, 1439-1453. [CrossRef] [PubMed]

140. Cutter, A.R.; Hayes, J.J. A brief review of nucleosome structure. Febs Lett. 2015, 589, 2914-2922. [CrossRef] [PubMed]

141. Füllgrabe, J.; Kavanagh, E.; Joseph, B. Histone onco-modifications. Oncogene 2011, 30, 3391. [CrossRef] [PubMed]

142. Kouzarides, T. Chromatin modifications and their function. Cell 2007, 128, 693-705. [CrossRef] [PubMed]

143. Sawan, C.; Herceg, Z. Histone modifications and cancer. In Advances in Genetics; Elsevier: Lyon, France, 2010; Volume 70, pp. 57-85.

144. Taby, R.; Issa, J.P.J. Cancer epigenetics. Cancer J. Clin. 2010, 60, 376-392. [CrossRef] [PubMed]

145. Utley, R.T.; Ikeda, K.; Grant, P.A.; Côté, J.; Steger, D.J.; Eberharter, A.; John, S.; Workman, J.L. Transcriptional activators direct histone acetyltransferase complexes to nucleosomes. Nature 1998, 394, 498. [CrossRef] [PubMed]

146. Yang, X.J. The diverse superfamily of lysine acetyltransferases and their roles in leukemia and other diseases. Nucleic Acids Res. 2004, 32, 959-976. [CrossRef]

147. Yang, X.; Seto, E. HATs and HDACs: from structure, function and regulation to novel strategies for therapy and prevention. Oncogene 2007, 26, 5310. [CrossRef]

148. Albert, M.; Helin, K. Seminars in cell \& developmental biology, 2010. In Histone Methyltransferases in Cancer; Elsevier: Copenhagen, Denmark, 2010; pp. 209-220.

149. Liu, L.; Kimball, S.; Liu, H.; Holowatyj, A.; Yang, Z.-Q. Genetic alterations of histone lysine methyltransferases and their significance in breast cancer. Oncotarget 2015, 6, 2466. [CrossRef]

150. Nair, V.S.; El Salhat, H.; Taha, R.Z.; John, A.; Ali, B.R.; Elkord, E. DNA methylation and repressive H3K9 and H3K27 trimethylation in the promoter regions of PD-1, CTLA-4, TIM-3, LAG-3, TIGIT, and PD-L1 genes in human primary breast cancer. Clin. Epigenetics 2018, 10, 78. [CrossRef] [PubMed] 
151. Okonkwo, A.; Mitra, J.; Johnson, G.S.; Li, L.; Dashwood, W.M.; Hegde, M.L.; Yue, C.; Dashwood, R.H.; Rajendran, P. Heterocyclic analogs of sulforaphane trigger DNA damage and impede DNA repair in colon cancer cells: interplay of HATs and HDACs. Mol. Nutr. Food Res. 2018, 62, 1800228. [CrossRef]

152. Lu, J.; Getz, G.; Miska, E.A.; Alvarez-Saavedra, E.; Lamb, J.; Peck, D.; Sweet-Cordero, A.; Ebert, B.L.; Mak, R.H.; Ferrando, A.A. MicroRNA expression profiles classify human cancers. Nature 2005, 435, 834. [CrossRef] [PubMed]

153. Calin, G.A.; Dumitru, C.D.; Shimizu, M.; Bichi, R.; Zupo, S.; Noch, E.; Aldler, H.; Rattan, S.; Keating, M.; Rai, K. Frequent deletions and down-regulation of micro-RNA genes miR15 and miR16 at 13q14 in chronic lymphocytic leukemia. Proc. Natl. Acad. Sci. USA 2002, 99, 15524-15529. [CrossRef] [PubMed]

154. Iorio, M.V.; Piovan, C.; Croce, C.M. Interplay between microRNAs and the epigenetic machinery: An intricate network. Biochim. Et Biophys. Acta (Bba)-Gene Regul. Mech. 2010, 1799, 694-701. [CrossRef]

155. Lopez-Serra, P.; Esteller, M. DNA methylation-associated silencing of tumor-suppressor microRNAs in cancer. Oncogene 2012, 31, 1609. [CrossRef] [PubMed]

156. Calin, G.A.; Ferracin, M.; Cimmino, A.; Di Leva, G.; Shimizu, M.; Wojcik, S.E.; Iorio, M.V.; Visone, R.; Sever, N.I.; Fabbri, M. A MicroRNA signature associated with prognosis and progression in chronic lymphocytic leukemia. New Engl. J. Med. 2005, 353, 1793-1801. [CrossRef] [PubMed]

157. Chang, T.-C.; Wentzel, E.A.; Kent, O.A.; Ramachandran, K.; Mullendore, M.; Lee, K.H.; Feldmann, G.; Yamakuchi, M.; Ferlito, M.; Lowenstein, C.J. Transactivation of miR-34a by p53 broadly influences gene expression and promotes apoptosis. Mol. Cell 2007, 26, 745-752. [CrossRef]

158. Raver-Shapira, N.; Marciano, E.; Meiri, E.; Spector, Y.; Rosenfeld, N.; Moskovits, N.; Bentwich, Z.; Oren, M. Transcriptional activation of miR-34a contributes to p53-mediated apoptosis. Mol. Cell 2007, 26, 731-743. [CrossRef]

159. Lehmann, U.; Hasemeier, B.; Christgen, M.; Müller, M.; Römermann, D.; Länger, F.; Kreipe, H. Epigenetic inactivation of microRNA gene hsa-mir-9-1 in human breast cancer. J. Pathol. 2008, 214, 17-24.

160. Toyota, M.; Suzuki, H.; Sasaki, Y.; Maruyama, R.; Imai, K.; Shinomura, Y.; Tokino, T. Epigenetic silencing of microRNA-34b/c and B-cell translocation gene 4 is associated with CpG island methylation in colorectal cancer. Cancer Res. 2008, 68, 4123-4132. [CrossRef] [PubMed]

161. Lujambio, A.; Calin, G.A.; Villanueva, A.; Ropero, S.; Sánchez-Céspedes, M.; Blanco, D.; Montuenga, L.M.; Rossi, S.; Nicoloso, M.S.; Faller, W.J. A microRNA DNA methylation signature for human cancer metastasis. Proc. Natl. Acad. Sci. USA 2008, 105, 13556-13561. [CrossRef] [PubMed]

162. Weber, B.; Stresemann, C.; Brueckner, B.; Lyko, F. Methylation of human microRNA genes in normal and neoplastic cells. Cell Cycle 2007, 6, 1001-1005. [CrossRef] [PubMed]

163. Chakrabarti, M.; Banik, N.L.; Ray, S.K. miR-138 overexpression is more powerful than hTERT knockdown to potentiate apigenin for apoptosis in neuroblastoma in vitro and in vivo. Exp. Cell Res. 2013, 319, 1575-1585. [CrossRef] [PubMed]

164. Chunhua, L.; Donglan, L.; Xiuqiong, F.; Lihua, Z.; Qin, F.; Yawei, L.; Liang, Z.; Ge, W.; Linlin, J.; Ping, Z. Apigenin up-regulates transgelin and inhibits invasion and migration of colorectal cancer through decreased phosphorylation of AKT. J. Nutr. Biochem. 2013, 24, 1766-1775. [CrossRef]

165. Fang, M.; Chen, D.; Yang, C.S. Dietary polyphenols may affect DNA methylation. J. Nutr. 2007, 137, 223S-228S. [CrossRef]

166. Kuo, C.-H.; Weng, B.-C.; Wu, C.-C.; Yang, S.-F.; Wu, D.-C.; Wang, Y.-C. Apigenin has anti-atrophic gastritis and anti-gastric cancer progression effects in Helicobacter pylori-infected Mongolian gerbils. J. Ethnopharmacol. 2014, 151, 1031-1039. [CrossRef]

167. Pandey, M.; Kaur, P.; Shukla, S.; Abbas, A.; Fu, P.; Gupta, S. Plant flavone apigenin inhibits HDAC and remodels chromatin to induce growth arrest and apoptosis in human prostate cancer cells: in vitro and in vivo study. Mol. Carcinog. 2012, 51, 952-962. [CrossRef]

168. Paredes-Gonzalez, X.; Fuentes, F.; Su, Z.-Y.; Kong, A.-N.T. Apigenin reactivates Nrf2 anti-oxidative stress signaling in mouse skin epidermal JB6 P+ cells through epigenetics modifications. Aaps J. 2014, 16, 727-735. [CrossRef]

169. Kumar, S.; Pandey, A.K. Chemistry and biological activities of flavonoids: An overview. Sci. World J. 2013, 2013. [CrossRef]

170. Zheng, P.-W.; Chiang, L.-C.; Lin, C.-C. Apigenin induced apoptosis through p53-dependent pathway in human cervical carcinoma cells. Life Sci. 2005, 76, 1367-1379. [CrossRef] [PubMed] 
171. Du, L.; Xie, Z.; Wu, L.-C.; Chiu, M.; Lin, J.; Chan, K.K.; Liu, S.; Liu, Z. Reactivation of RASSF1A in breast cancer cells by curcumin. Nutr. Cancer 2012, 64, 1228-1235. [CrossRef] [PubMed]

172. Khor, T.O.; Huang, Y.; Wu, T.-Y.; Shu, L.; Lee, J.; Kong, A.-N.T. Pharmacodynamics of curcumin as DNA hypomethylation agent in restoring the expression of Nrf2 via promoter CpGs demethylation. Biochem. Pharmacol. 2011, 82, 1073-1078. [CrossRef] [PubMed]

173. Link, A.; Balaguer, F.; Shen, Y.; Lozano, J.J.; Leung, H.-C.E.; Boland, C.R.; Goel, A. Curcumin modulates DNA methylation in colorectal cancer cells. PLoS ONE 2013, 8, e57709. [CrossRef] [PubMed]

174. Shu, L.; Khor, T.O.; Lee, J.-H.; Boyanapalli, S.S.; Huang, Y.; Wu, T.-Y.; Saw, C.L.-L.; Cheung, K.-L.; Kong, A.-N.T. Epigenetic $\mathrm{CPG}$ demethylation of the promoter and reactivation of the expression of Neurog1 by curcumin in prostate LNCaP cells. Aaps J. 2011, 13, 606-614. [CrossRef] [PubMed]

175. Aygul, I.; Yaylaci Karahalil, F.; Supuran, C.T. Investigation of the inhibitory properties of some phenolic standards and bee products against human carbonic anhydrase I and II. J. Enzym. Inhib. Med. Chem. 2016, 31, 119-124. [CrossRef] [PubMed]

176. Karioti, A.; Carta, F.; Supuran, C. Phenols and polyphenols as carbonic anhydrase inhibitors. Molecules 2016, 21, 1649. [CrossRef] [PubMed]

177. Kim, S.W.; Cha, M.-J.; Lee, S.-K.; Song, B.-W.; Jin, X.; Lee, J.M.; Park, J.H.; Lee, J.D. Curcumin Treatment in Combination with Glucose Restriction Inhibits Intracellular Alkalinization and Tumor Growth in Hepatoma Cells. Int. J. Mol. Sci. 2019, 20, 2375. [CrossRef] [PubMed]

178. Ramya, P.S.; Angapelly, S.; Angeli, A.; Digwal, C.S.; Arifuddin, M.; Babu, B.N.; Supuran, C.T.; Kamal, A. Discovery of curcumin inspired sulfonamide derivatives as a new class of carbonic anhydrase isoforms I, II, IX, and XII inhibitors. J. Enzym. Inhib. Med. Chem. 2017, 32, 1274-1281. [CrossRef]

179. Şentürk, M.; Gülçin, İ.; Beydemir, Ş.; Küfrevioğlu, Ö.İ.; Supuran, C.T. In vitro inhibition of human carbonic anhydrase I and II isozymes with natural phenolic compounds. Chem. Biol. Drug Des. 2011, 77, 494-499. [CrossRef]

180. Liontas, A.; Yeger, H. Curcumin and resveratrol induce apoptosis and nuclear translocation and activation of p53 in human neuroblastoma. Anticancer Res. 2004, 24, 987-998. [PubMed]

181. Rasyid, A.; Rahman, A.R.A.; Jaalam, K.; Lelo, A. Effect of different curcumin dosages on human gall bladder. Asia Pac. J. Clin. Nutr. 2002, 11, 314-318. [CrossRef] [PubMed]

182. Strimpakos, A.S.; Sharma, R.A. Curcumin: Preventive and therapeutic properties in laboratory studies and clinical trials. Antioxid. Redox Signal. 2008, 10, 511-546. [CrossRef] [PubMed]

183. Magee, P.J.; Allsopp, P.; Samaletdin, A.; Rowland, I.R. Daidzein, R-(+) equol and S-(-) equol inhibit the invasion of MDA-MB-231 breast cancer cells potentially via the down-regulation of matrix metalloproteinase-2. Eur. J. Nutr. 2014, 53, 345-350. [CrossRef] [PubMed]

184. Park, H.J.; Jeon, Y.K.; You, D.H.; Nam, M.J. Daidzein causes cytochrome c-mediated apoptosis via the Bcl-2 family in human hepatic cancer cells. Food Chem. Toxicol. 2013, 60, 542-549. [CrossRef]

185. Bin Hafeez, B.; Asim, M.; Siddiqui, I.A.; Adhami, V.M.; Murtaza, I.; Mukhtar, H. Delphinidin, a dietary anthocyanidin in pigmented fruits and vegetables: a new weapon to blunt prostate cancer growth. Cell Cycle 2008, 7, 3320-3326. [CrossRef]

186. Lamy, S.; Blanchette, M.; Michaud-Levesque, J.; Lafleur, R.; Durocher, Y.; Moghrabi, A.; Barrette, S.; Gingras, D.; Béliveau, R. Delphinidin, a dietary anthocyanidin, inhibits vascular endothelial growth factor receptor-2 phosphorylation. Carcinogenesis 2005, 27, 989-996. [CrossRef]

187. Pal, H.C.; Sharma, S.; Strickland, L.R.; Agarwal, J.; Athar, M.; Elmets, C.A.; Afaq, F. Delphinidin reduces cell proliferation and induces apoptosis of non-small-cell lung cancer cells by targeting EGFR/VEGFR2 signaling pathways. PLoS ONE 2013, 8, e77270. [CrossRef]

188. Yun, J.M.; Afaq, F.; Khan, N.; Mukhtar, H. Delphinidin, an anthocyanidin in pigmented fruits and vegetables, induces apoptosis and cell cycle arrest in human colon cancer HCT116 cells. Mol. Carcinog. Publ. Coop. Univ. Tex. Md Anderson Cancer Cent. 2009, 48, 260-270. [CrossRef]

189. Feng, J.; Chen, X.; Wang, Y.; Du, Y.; Sun, Q.; Zang, W.; Zhao, G. Myricetin inhibits proliferation and induces apoptosis and cell cycle arrest in gastric cancer cells. Mol. Cell. Biochem. 2015, 408, 163-170. [CrossRef]

190. Kim, M.E.; Ha, T.K.; Yoon, J.H.; Lee, J.S. Myricetin induces cell death of human colon cancer cells via BAX/BCL2-dependent pathway. Anticancer Res. 2014, 34, 701-706. [PubMed]

191. Ratovitski, E.A. Anticancer natural compounds as epigenetic modulators of gene expression. Curr. Genom. 2017, 18, 175. [CrossRef] [PubMed] 
192. Wang, L.-S.; Kuo, C.-T.; Cho, S.-J.; Seguin, C.; Siddiqui, J.; Stoner, K.; Weng, Y.-I.; Huang, T.H.-M.; Tichelaar, J.; Yearsley, M. Black raspberry-derived anthocyanins demethylate tumor suppressor genes through the inhibition of DNMT1 and DNMT3B in colon cancer cells. Nutr. Cancer 2013, 65, 118-125. [CrossRef] [PubMed]

193. Paluszczak, J.; Krajka-Kuźniak, V.; Baer-Dubowska, W. The effect of dietary polyphenols on the epigenetic regulation of gene expression in MCF7 breast cancer cells. Toxicol. Lett. 2010, 192, 119-125. [CrossRef] [PubMed]

194. Kowshik, J.; Giri, H.; Kranthi Kiran Kishore, T.; Kesavan, R.; Naik Vankudavath, R.; Bhanuprakash Reddy, G.; Dixit, M.; Nagini, S. Ellagic acid inhibits VEGF/VEGFR2, PI3K/Akt and MAPK signaling cascades in the hamster cheek pouch carcinogenesis model. Anti-Cancer Agents Med. Chem. (Former. Curr. Med. Chem. -Anti-Cancer Agents) 2014, 14, 1249-1260. [CrossRef]

195. Huang, S.-T.; Yang, R.-C.; Wu, H.-T.; Wang, C.-N.; Pang, J.-H.S. Zinc-chelation contributes to the anti-angiogenic effect of ellagic acid on inhibiting MMP-2 activity, cell migration and tube formation. PLoS ONE 2011, 6, e18986. [CrossRef] [PubMed]

196. Cerezo-Guisado, M.I.; Zur, R.; Lorenzo, M.J.; Risco, A.; Martín-Serrano, M.A.; Alvarez-Barrientos, A.; Cuenda, A.; Centeno, F. Implication of Akt, ERK1/2 and alternative p38MAPK signalling pathways in human colon cancer cell apoptosis induced by green tea EGCG. Food Chem. Toxicol. 2015, 84, 125-132. [CrossRef]

197. Deng, Y.-T.; Lin, J.-K. EGCG inhibits the invasion of highly invasive CL1-5 lung cancer cells through suppressing MMP-2 expression via JNK signaling and induces G2/M arrest. J. Agric. Food Chem. 2011, 59, 13318-13327. [CrossRef]

198. Onoda, C.; Kuribayashi, K.; Nirasawa, S.; Tsuji, N.; Tanaka, M.; Kobayashi, D.; Watanabe, N. (-)-Epigallocatechin-3-gallate induces apoptosis in gastric cancer cell lines by down-regulating survivin expression. Int. J. Oncol. 2011, 38, 1403-1408.

199. Siddiqui, I.A.; Asim, M.; Hafeez, B.B.; Adhami, V.M.; Tarapore, R.S.; Mukhtar, H. Green tea polyphenol EGCG blunts androgen receptor function in prostate cancer. Faseb J. 2011, 25, 1198-1207. [CrossRef]

200. Tanaka, T.; Ishii, T.; Mizuno, D.; Mori, T.; Yamaji, R.; Nakamura, Y.; Kumazawa, S.; Nakayama, T.; Akagawa, M. (-)-Epigallocatechin-3-gallate suppresses growth of AZ521 human gastric cancer cells by targeting the DEAD-box RNA helicase p68. Free Radic. Biol. Med. 2011, 50, 1324-1335. [CrossRef] [PubMed]

201. Tu, S.H.; Ku, C.Y.; Ho, C.T.; Chen, C.S.; Huang, C.S.; Lee, C.H.; Chen, L.C.; Pan, M.H.; Chang, H.W.; Chang, C.H. Tea polyphenol (-)-epigallocatechin-3-gallate inhibits nicotine-and estrogen-induced $\alpha 9$-nicotinic acetylcholine receptor upregulation in human breast cancer cells. Mol. Nutr. Food Res. 2011, 55, 455-466. [CrossRef] [PubMed]

202. Khan, M.A.; Hussain, A.; Sundaram, M.K.; Alalami, U.; Gunasekera, D.; Ramesh, L.; Hamza, A.; Quraishi, U. (-)-Epigallocatechin-3-gallate reverses the expression of various tumor-suppressor genes by inhibiting DNA methyltransferases and histone deacetylases in human cervical cancer cells. Oncol. Rep. 2015, 33, 1976-1984. [CrossRef] [PubMed]

203. Saldanha, S.N.; Kala, R.; Tollefsbol, T.O. Molecular mechanisms for inhibition of colon cancer cells by combined epigenetic-modulating epigallocatechin gallate and sodium butyrate. Exp. Cell Res. 2014, 324, 40-53. [CrossRef] [PubMed]

204. Ferreira, N.; Cardoso, I.; Domingues, M.R.; Vitorino, R.; Bastos, M.; Bai, G.; Saraiva, M.J.; Almeida, M.R. Binding of epigallocatechin-3-gallate to transthyretin modulates its amyloidogenicity. Febs Lett. 2009, 583, 3569-3576. [CrossRef] [PubMed]

205. Guo, S.; Yang, S.; Taylor, C.; Sonenshein, G.E. Green tea polyphenol epigallocatechin-3 gallate (EGCG) affects gene expression of breast cancer cells transformed by the carcinogen 7, 12-dimethylbenz [a] anthracene. J. Nutr. 2005, 135, 2978S-2986S. [CrossRef] [PubMed]

206. Balasubramanian, S.; Adhikary, G.; Eckert, R.L. The Bmi-1 polycomb protein antagonizes the (-)-epigallocatechin-3-gallate-dependent suppression of skin cancer cell survival. Carcinogenesis 2009, 31, 496-503. [CrossRef]

207. Choudhury, S.R.; Balasubramanian, S.; Chew, Y.C.; Han, B.; Marquez, V.E.; Eckert, R.L. (-)-Epigallocatechin-3-gallate and DZNep reduce polycomb protein level via a proteasome-dependent mechanism in skin cancer cells. Carcinogenesis 2011, 32, 1525-1532. [CrossRef] 
208. Nandakumar, V.; Vaid, M.; Katiyar, S.K. (-)-Epigallocatechin-3-gallate reactivates silenced tumor suppressor genes, Cip1/p21 and p 16 INK4a, by reducing DNA methylation and increasing histones acetylation in human skin cancer cells. Carcinogenesis 2011, 32, 537-544. [CrossRef]

209. Alshatwi, A.A.; Ramesh, E.; Periasamy, V.; Subash-Babu, P. The apoptotic effect of hesperetin on human cervical cancer cells is mediated through cell cycle arrest, death receptor, and mitochondrial pathways. Fundam. Clin. Pharmacol. 2013, 27, 581-592. [CrossRef]

210. Aranganathan, S.; Nalini, N. Antiproliferative efficacy of hesperetin (citrus flavanoid) in 1, 2-dimethylhydrazine-induced colon cancer. Phytother. Res. 2013, 27, 999-1005. [CrossRef] [PubMed]

211. Cincin, Z.; Kiran, B.; Baran, Y.; Cakmakoglu, B. Hesperidin promotes programmed cell death by downregulation of nongenomic estrogen receptor signalling pathway in endometrial cancer cells. Biomed. Pharmacother. 2018, 103, 336-345. [CrossRef] [PubMed]

212. Palit, S.; Kar, S.; Sharma, G.; Das, P.K. Hesperetin induces apoptosis in breast carcinoma by triggering accumulation of ROS and activation of ASK1/JNK pathway. J. Cell. Physiol. 2015, 230, 1729-1739. [CrossRef] [PubMed]

213. Sambantham, S.; Radha, M.; Paramasivam, A.; Anandan, B.; Malathi, R.; Chandra, S.R.; Jayaraman, G. Molecular mechanism underlying hesperetin-induced apoptosis by in silico analysis and in prostate cancer PC-3 cells. Asian Pac. J. Cancer Prev. 2013, 14, 4347-4352. [CrossRef] [PubMed]

214. Yang, Y.; Wolfram, J.; Boom, K.; Fang, X.; Shen, H.; Ferrari, M. Hesperetin impairs glucose uptake and inhibits proliferation of breast cancer cells. Cell Biochem. Funct. 2013, 31, 374-379. [CrossRef] [PubMed]

215. Zhang, J.; Wu, D.; Song, J.; Wang, J.; Yi, J.; Dong, W. Hesperetin induces the apoptosis of gastric cancer cells via activating mitochondrial pathway by increasing reactive oxygen species. Dig. Dis. Sci. 2015, 60, 2985-2995. [CrossRef] [PubMed]

216. Azevedo, C.; Correia-Branco, A.; Araújo, J.R.; Guimarães, J.T.; Keating, E.; Martel, F. The chemopreventive effect of the dietary compound kaempferol on the MCF-7 human breast cancer cell line is dependent on inhibition of glucose cellular uptake. Nutr. Cancer 2015, 67, 504-513. [CrossRef] [PubMed]

217. Jo, E.; Park, S.J.; Choi, Y.S.; Jeon, W.-K.; Kim, B.-C. Kaempferol suppresses transforming growth factor- $\beta 1$-induced epithelial-to-mesenchymal transition and migration of A549 lung cancer cells by inhibiting Akt1-mediated phosphorylation of Smad3 at threonine-179. Neoplasia 2015, 17, 525-537. [CrossRef] [PubMed]

218. Kim, S.-H.; Hwang, K.-A.; Choi, K.-C. Treatment with kaempferol suppresses breast cancer cell growth caused by estrogen and triclosan in cellular and xenograft breast cancer models. J. Nutr. Biochem. 2016, 28, 70-82. [CrossRef]

219. Kim, T.W.; Lee, S.Y.; Kim, M.; Cheon, C.; Ko, S.-G. Kaempferol induces autophagic cell death via IRE1-JNK-CHOP pathway and inhibition of G9a in gastric cancer cells. Cell Death Dis. 2018, 9, 875. [CrossRef]

220. Lee, H.; Cho, H.; Yu, R.; Lee, K.; Chun, H.; Park, J. Mechanisms underlying apoptosis-inducing effects of Kaempferol in HT-29 human colon cancer cells. Int. J. Mol. Sci. 2014, 15, 2722-2737. [CrossRef] [PubMed]

221. Song, H.; Bao, J.; Wei, Y.; Chen, Y.; Mao, X.; Li, J.; Yang, Z.; Xue, Y. Kaempferol inhibits gastric cancer tumor growth: An in vitro and in vivo study. Oncol. Rep. 2015, 33, 868-874. [CrossRef] [PubMed]

222. Cai, X.; Ye, T.; Liu, C.; Lu, W.; Lu, M.; Zhang, J.; Wang, M.; Cao, P. Luteolin induced G2 phase cell cycle arrest and apoptosis on non-small cell lung cancer cells. Toxicol. Vitro 2011, 25, 1385-1391. [CrossRef] [PubMed]

223. Choi, H.-J.; Choi, H.-J.; Chung, T.-W.; Ha, K.-T. Luteolin inhibits recruitment of monocytes and migration of Lewis lung carcinoma cells by suppressing chemokine (C-C motif) ligand 2 expression in tumor-associated macrophage. Biochem. Biophys. Res. Commun. 2016, 470, 101-106. [CrossRef] [PubMed]

224. Kim, Y.S.; Kim, S.-H.; Shin, J.; Harikishore, A.; Lim, J.-K.; Jung, Y.; Lyu, H.-N.; Baek, N.-I.; Choi, K.Y.; Yoon, H.S. Luteolin suppresses cancer cell proliferation by targeting vaccinia-related kinase 1. PLoS ONE 2014, 9, e109655. [CrossRef] [PubMed]

225. Lu, J.; Li, G.; He, K.; Jiang, W.; Xu, C.; Li, Z.; Wang, H.; Wang, W.; Wang, H.; Teng, X. Luteolin exerts a marked antitumor effect in cMet-overexpressing patient-derived tumor xenograft models of gastric cancer. J. Transl. Med. 2015, 13, 42. [CrossRef] [PubMed]

226. Ruan, J.; Zhang, L.; Yan, L.; Liu, Y.; Yue, Z.; Chen, L.; Wang, A.-Y.; Chen, W.; Zheng, S.; Wang, S. Inhibition of hypoxia-induced epithelial mesenchymal transition by luteolin in non-small cell lung cancer cells. Mol. Med. Rep. 2012, 6, 232-238. [PubMed] 
227. Wang, L.-M.; Xie, K.-P.; Huo, H.-N.; Shang, F.; Zou, W.; Xie, M.-J. Luteolin inhibits proliferation induced by IGF-1 pathway dependent ER $\alpha$ in human breast cancer MCF-7 cells. Asian Pac. J. Cancer Prev. 2012, 13, 1431-1437. [CrossRef] [PubMed]

228. Wu, C.-H.; Hong, B.-H.; Ho, C.-T.; Yen, G.-C. Targeting cancer stem cells in breast cancer: potential anticancer properties of 6-shogaol and pterostilbene. J. Agric. Food Chem. 2015, 63, 2432-2441. [CrossRef]

229. Su, C.-M.; Lee, W.-H.; Wu, A.T.; Lin, Y.-K.; Wang, L.-S.; Wu, C.-H.; Yeh, C.-T. Pterostilbene inhibits triple-negative breast cancer metastasis via inducing microRNA-205 expression and negatively modulates epithelial-to-mesenchymal transition. J. Nutr. Biochem. 2015, 26, 675-685. [CrossRef]

230. Lin, V.C.-H.; Tsai, Y.-C.; Lin, J.-N.; Fan, L.-L.; Pan, M.-H.; Ho, C.-T.; Wu, J.-Y.; Way, T.-D. Activation of AMPK by pterostilbene suppresses lipogenesis and cell-cycle progression in p53 positive and negative human prostate cancer cells. J. Agric. Food Chem. 2012, 60, 6399-6407. [CrossRef] [PubMed]

231. Kala, R.; Tollefsbol, T.O. A novel combinatorial epigenetic therapy using resveratrol and pterostilbene for restoring estrogen receptor- $\alpha(\mathrm{ER} \alpha)$ expression in ER $\alpha$-negative breast cancer cells. PLoS ONE 2016, 11, e0155057. [CrossRef] [PubMed]

232. Dhar, S.; Kumar, A.; Rimando, A.M.; Zhang, X.; Levenson, A.S. Resveratrol and pterostilbene epigenetically restore PTEN expression by targeting oncomiRs of the miR-17 family in prostate cancer. Oncotarget 2015, 6, 27214. [CrossRef] [PubMed]

233. Amatori, S.; Mazzoni, L.; Alvarez-Suarez, J.M.; Giampieri, F.; Gasparrini, M.; Forbes-Hernandez, T.Y.; Afrin, S.; Provenzano, A.E.; Persico, G.; Mezzetti, B. Polyphenol-rich strawberry extract (PRSE) shows in vitro and in vivo biological activity against invasive breast cancer cells. Sci. Rep. 2016, 6, 30917. [CrossRef] [PubMed]

234. Mahmoud, A.M.; Zhu, T.; Parray, A.; Siddique, H.R.; Yang, W.; Saleem, M.; Bosland, M.C. Differential effects of genistein on prostate cancer cells depend on mutational status of the androgen receptor. PLOS ONE 2013, 8, e78479. [CrossRef] [PubMed]

235. Pan, H.; Zhou, W.; He, W.; Liu, X.; Ding, Q.; Ling, L.; Zha, X.; Wang, S. Genistein inhibits MDA-MB-231 triple-negative breast cancer cell growth by inhibiting NF-кB activity via the Notch-1 pathway. Int. J. Mol. Med. 2012, 30, 337-343. [CrossRef]

236. Rigalli, J.P.; Tocchetti, G.N.; Arana, M.R.; Villanueva, S.S.M.; Catania, V.A.; Theile, D.; Ruiz, M.L.; Weiss, J. The phytoestrogen genistein enhances multidrug resistance in breast cancer cell lines by translational regulation of ABC transporters. Cancer Lett. 2016, 376, 165-172. [CrossRef]

237. Tian, T.; Li, J.; Li, B.; Wang, Y.; Li, M.; Ma, D.; Wang, X. Genistein exhibits anti-cancer effects via down-regulating FoxM1 in H446 small-cell lung cancer cells. Tumor Biol. 2014, 35, 4137-4145. [CrossRef]

238. Caldarelli, A.; Diel, P.; Vollmer, G. Effect of phytoestrogens on gene expression of carbonic anhydrase II in rat uterus and liver. J. Steroid Biochem. Mol. Biol. 2005, 97, 251-256. [CrossRef]

239. Norrby, M.; Madej, A.; Ekstedt, E.; Holm, L. Effects of genistein on oestrogen and progesterone receptor, proliferative marker Ki-67 and carbonic anhydrase localisation in the uterus and cervix of gilts after insemination. Anim. Reprod. Sci. 2013, 138, 90-101. [CrossRef]

240. Zhang, Y.; Li, Q.; Wan, H.-Y.; Helferich, W.G.; Wong, M.-S. Genistein and a soy extract differentially affect three-dimensional bone parameters and bone-specific gene expression in ovariectomized mice. J. Nutr. 2009, 139, 2230-2236. [CrossRef] [PubMed]

241. Majid, S.; Dar, A.A.; Ahmad, A.E.; Hirata, H.; Kawakami, K.; Shahryari, V.; Saini, S.; Tanaka, Y.; Dahiya, A.V.; Khatri, G. BTG3 tumor suppressor gene promoter demethylation, histone modification and cell cycle arrest by genistein in renal cancer. Carcinogenesis 2009, 30, 662-670. [CrossRef] [PubMed]

242. Majid, S.; Dar, A.A.; Shahryari, V.; Hirata, H.; Ahmad, A.; Saini, S.; Tanaka, Y.; Dahiya, A.V.; Dahiya, R. Genistein reverses hypermethylation and induces active histone modifications in tumor suppressor gene B-Cell translocation gene 3 in prostate cancer. Cancer: Interdiscip. Int. J. Am. Cancer Soc. 2010, 116, 66-76. [CrossRef]

243. Zhao, B.; Hu, M. Gallic acid reduces cell viability, proliferation, invasion and angiogenesis in human cervical cancer cells. Oncol. Lett. 2013, 6, 1749-1755. [CrossRef] [PubMed]

244. Liu, K.-C.; Huang, A.-C.; Wu, P.-P.; Lin, H.-Y.; Chueh, F.-S.; Yang, J.-S.; Lu, C.-C.; Chiang, J.-H.; Meng, M.; Chung, J.-G. Gallic acid suppresses the migration and invasion of PC-3 human prostate cancer cells via inhibition of matrix metalloproteinase-2 and-9 signaling pathways. Oncol. Rep. 2011, 26, 177-184. [PubMed] 
245. Liu, K.C.; Ho, H.C.; Huang, A.C.; Ji, B.C.; Lin, H.Y.; Chueh, F.S.; Yang, J.S.; Lu, C.C.; Chiang, J.H.; Meng, M. Gallic acid provokes DNA damage and suppresses DNA repair gene expression in human prostate cancer PC-3 cells. Environ. Toxicol. 2013, 28, 579-587. [CrossRef] [PubMed]

246. Li, Y.; Tollefsbol, T.O. Impact on DNA methylation in cancer prevention and therapy by bioactive dietary components. Curr. Med. Chem. 2010, 17, 2141-2151. [CrossRef] [PubMed]

247. Kam, A.; Li, K.M.; Razmovski-Naumovski, V.; Nammi, S.; Chan, K.; Li, G.Q. Gallic acid protects against endothelial injury by restoring the depletion of DNA methyltransferase 1 and inhibiting proteasome activities. Int. J. Cardiol. 2014, 171, 231-242. [CrossRef] [PubMed]

248. Yen, H.-R.; Liu, C.-J.; Yeh, C.-C. Naringenin suppresses TPA-induced tumor invasion by suppressing multiple signal transduction pathways in human hepatocellular carcinoma cells. Chem. Biol. Interact. 2015, 235, 1-9. [CrossRef]

249. Song, H.M.; Park, G.H.; Eo, H.J.; Jeong, J.B. Naringenin-mediated ATF3 expression contributes to apoptosis in human colon cancer. Biomol. Ther. 2016, 24, 140. [CrossRef] [PubMed]

250. Jin, C.Y.; Park, C.; Hwang, H.J.; Kim, G.Y.; Choi, B.T.; Kim, W.J.; Choi, Y.H. Naringenin up-regulates the expression of death receptor 5 and enhances TRAIL-induced apoptosis in human lung cancer A549 cells. Mol. Nutr. Food Res. 2011, 55, 300-309. [CrossRef]

251. Reinders, J.; Vivier, C.D.; Theiler, G.; Chollet, D.; Descombes, P.; Paszkowski, J. Genome-wide, high-resolution DNA methylation profiling using bisulfite-mediated cytosine conversion. Genome Res. 2008, 18, 469-476. [CrossRef] [PubMed]

252. Zhang, H.; Jia, R.; Wang, C.; Hu, T.; Wang, F. Piceatannol promotes apoptosis via up-regulation of microRNA-129 expression in colorectal cancer cell lines. Biochem. Biophys. Res. Commun. 2014, 452, 775-781. [CrossRef] [PubMed]

253. Kwon, G.T.; Jung, J.I.; Song, H.R.; Woo, E.Y.; Jun, J.-G.; Kim, J.-K.; Her, S.; Park, J.H.Y. Piceatannol inhibits migration and invasion of prostate cancer cells: possible mediation by decreased interleukin-6 signaling. $J$. Nutr. Biochem. 2012, 23, 228-238. [CrossRef] [PubMed]

254. Hsieh, T.-C.; Lin, C.-Y.; Lin, H.-Y.; Wu, J.M. AKT/mTOR as novel targets of polyphenol piceatannol possibly contributing to inhibition of proliferation of cultured prostate cancer cells. Isrn Urol. 2012, 2012, 272697. [CrossRef]

255. Wang, K.; Liu, R.; Li, J.; Mao, J.; Lei, Y.; Wu, J.; Zeng, J.; Zhang, T.; Wu, H.; Chen, L. Quercetin induces protective autophagy in gastric cancer cells: involvement of Akt-mTOR-and hypoxia-induced factor $1 \alpha$-mediated signaling. Autophagy 2011, 7, 966-978. [CrossRef]

256. Velázquez, K.T.; Enos, R.T.; Narsale, A.A.; Puppa, M.J.; Davis, J.M.; Murphy, E.A.; Carson, J.A. Quercetin supplementation attenuates the progression of cancer cachexia in ApcMin/+ mice. J. Nutr. 2014, 144, 868-875. [CrossRef]

257. Dai, W.; Gao, Q.; Qiu, J.; Yuan, J.; Wu, G.; Shen, G. Quercetin induces apoptosis and enhances 5-FU therapeutic efficacy in hepatocellular carcinoma. Tumor Biol. 2016, 37, 6307-6313. [CrossRef]

258. Beyza Öztürk Sarıkaya, S.; Gülçin, İ.; Supuran, C.T. Carbonic anhydrase inhibitors: Inhibition of human erythrocyte isozymes I and II with a series of phenolic acids. Chem. Biol. Drug Des. 2010, 75, 515-520. [CrossRef]

259. Ekinci, D.; Karagoz, L.; Ekinci, D.; Senturk, M.; Supuran, C.T. Carbonic anhydrase inhibitors: in vitro inhibition of $\alpha$ isoforms (hCA I, hCA II, bCA III, hCA IV) by flavonoids. J. Enzym. Inhib. Med. Chem. 2013, 28, 283-288. [CrossRef]

260. Innocenti, A.; Sarıkaya, S.B.Ö.; Gülçin, I.; Supuran, C.T. Carbonic anhydrase inhibitors. Inhibition of mammalian isoforms I-XIV with a series of natural product polyphenols and phenolic acids. Bioorganic Med. Chem. 2010, 18, 2159-2164. [CrossRef] [PubMed]

261. Ma, T.; Liu, Y.; Wu, Q.; Luo, L.; Cui, Y.; Wang, X.; Chen, X.; Tan, L.; Meng, X. Quercetin-Modified Metal-Organic Frameworks for Dual Sensitization of Radiotherapy in Tumor Tissues by Inhibiting the Carbonic Anhydrase IX. Acs Nano 2019, 13, 4209-4219. [CrossRef] [PubMed]

262. Abdulla, A.; Zhao, X.; Yang, F. Natural polyphenols inhibit lysine-specific demethylase-1 in vitro. J. Biochem. Pharmacol. Res. 2013, 1, 56. [PubMed]

263. Yong, W.K.; Ho, Y.F.; Malek, S.N.A. Xanthohumol induces apoptosis and S phase cell cycle arrest in A549 non-small cell lung cancer cells. Pharmacogn. Mag. 2015, 11, S275. [PubMed] 
264. Wang, Y.; Chen, Y.; Wang, J.; Chen, J.; Aggarwal, B.; Pang, X.; Liu, M. Xanthohumol, a prenylated chalcone derived from hops, suppresses cancer cell invasion through inhibiting the expression of CXCR4 chemokine receptor. Curr. Mol. Med. 2012, 12, 153-162. [CrossRef] [PubMed]

265. Venè, R.; Benelli, R.; Minghelli, S.; Astigiano, S.; Tosetti, F.; Ferrari, N. Xanthohumol impairs human prostate cancer cell growth and invasion and diminishes the incidence and progression of advanced tumors in TRAMP mice. Mol. Med. 2012, 18, 1292-1302. [CrossRef]

266. Strathmann, J.; Peterssen, J.; Claus, R.; Knapp-Mohammedy, M.; Plass, C.; Gerhauser, C. Abstract B48: Xanthohumol from hops (Humulus lupulus L.) reactivates epigentically silenced genes by potential DNA methyltransferase inhibition. Am. Asso. Cancer Res. 2010. [CrossRef]

267. Reikvam, H.; Olsnes, A.M.; Gjertsen, B.T.; Ersvar, E.; Bruserud, O. Nuclear factor-кB signaling: a contributor in leukemogenesis and a target for pharmacological intervention in human acute myelogenous leukemia.

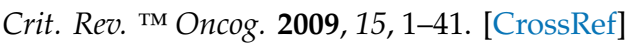

268. Shan, Y.; Zhang, L.; Bao, Y.; Li, B.; He, C.; Gao, M.; Feng, X.; Xu, W.; Zhang, X.; Wang, S. Epithelial-mesenchymal transition, a novel target of sulforaphane via COX-2/MMP2, 9/Snail, ZEB1 and miR-200c/ZEB1 pathways in human bladder cancer cells. J. Nutr. Biochem. 2013, 24, 1062-1069. [CrossRef]

269. Shan, Y.; Sun, C.; Zhao, X.; Wu, K.; Cassidy, A.; Bao, Y. Effect of sulforaphane on cell growth, G0/G1 phase cell progression and apoptosis in human bladder cancer T24 cells. Int. J. Oncol. 2006, 29, 883-888. [CrossRef]

270. Lewinska, A.; Adamczyk-Grochala, J.; Deregowska, A.; Wnuk, M. Sulforaphane-induced cell cycle arrest and senescence are accompanied by DNA hypomethylation and changes in microRNA profile in breast cancer cells. Theranostics 2017, 7, 3461. [CrossRef] [PubMed]

271. Atwell, L.L.; Beaver, L.M.; Shannon, J.; Williams, D.E.; Dashwood, R.H.; Ho, E. Epigenetic regulation by sulforaphane: opportunities for breast and prostate cancer chemoprevention. Curr. Pharmacol. Rep. 2015, 1, 102-111. [CrossRef] [PubMed]

272. Herman-Antosiewicz, A.; Xiao, H.; Lew, K.L.; Singh, S.V. Induction of p21 protein protects against sulforaphane-induced mitotic arrest in LNCaP human prostate cancer cell line. Mol. Cancer Ther. 2007, 6, 1673-1681. [CrossRef] [PubMed]

273. Jackson, S.J.; Singletary, K.W. Sulforaphane inhibits human MCF-7 mammary cancer cell mitotic progression and tubulin polymerization. J. Nutr. 2004, 134, 2229-2236. [CrossRef] [PubMed]

274. Rajendran, P.; Delage, B.; Dashwood, W.M.; Yu, T.-W.; Wuth, B.; Williams, D.E.; Ho, E.; Dashwood, R.H. Histone deacetylase turnover and recovery in sulforaphane-treated colon cancer cells: competing actions of 14-3-3 and Pin1 in HDAC3/SMRT corepressor complex dissociation/reassembly. Mol. Cancer 2011, 10, 68. [CrossRef]

275. Singh, S.V.; Herman-Antosiewicz, A.; Singh, A.V.; Lew, K.L.; Srivastava, S.K.; Kamath, R.; Brown, K.D.; Zhang, L.; Baskaran, R. Sulforaphane-induced G2/M phase cell cycle arrest involves checkpoint kinase 2-mediated phosphorylation of cell division cycle 25C. J. Biol. Chem. 2004, 279, 25813-25822. [CrossRef] [PubMed]

276. Yang, Q.; Wang, B.; Zang, W.; Wang, X.; Liu, Z.; Li, W.; Jia, J. Resveratrol inhibits the growth of gastric cancer by inducing G1 phase arrest and senescence in a Sirt1-dependent manner. PLoS ONE 2013, 8, e70627. [CrossRef]

277. Wang, Z.; Zhang, L.; Ni, Z.; Sun, J.; Gao, H.; Cheng, Z.; Xu, J.; Yin, P. Resveratrol induces AMPK-dependent MDR1 inhibition in colorectal cancer HCT116/L-OHP cells by preventing activation of NF- $\kappa$ B signaling and suppressing CAMP-responsive element transcriptional activity. Tumor Biol. 2015, 36, 9499-9510. [CrossRef]

278. Selvaraj, S.; Sun, Y.; Sukumaran, P.; Singh, B.B. Resveratrol activates autophagic cell death in prostate cancer cells via downregulation of STIM1 and the mTOR pathway. Mol. Carcinog. 2016, 55, 818-831. [CrossRef]

279. Qin, W.; Zhang, K.; Clarke, K.; Weiland, T.; Sauter, E.R. Methylation and miRNA effects of resveratrol on mammary tumors vs. normal tissue. Nutr. Cancer 2014, 66, 270-277. [CrossRef]

280. Miki, H.; Uehara, N.; Kimura, A.; Sasaki, T.; Yuri, T.; Yoshizawa, K.; Tsubura, A. Resveratrol induces apoptosis via ROS-triggered autophagy in human colon cancer cells. Int. J. Oncol. 2012, 40, 1020-1028. [CrossRef] [PubMed]

281. Ko, J.C.; Syu, J.J.; Chen, J.C.; Wang, T.J.; Chang, P.Y.; Chen, C.Y.; Jian, Y.T.; Jian, Y.J.; Lin, Y.W. Resveratrol Enhances Etoposide-Induced Cytotoxicity through Down-Regulating ERK 1/2 and AKT-Mediated X-ray Repair Cross-Complement Group 1 (XRCC 1) Protein Expression in Human Non-Small-Cell Lung Cancer Cells. Basic Clin. Pharmacol. Toxicol. 2015, 117, 383-391. [CrossRef] [PubMed] 
282. Ganapathy, S.; Chen, Q.; Singh, K.P.; Shankar, S.; Srivastava, R.K. Resveratrol enhances antitumor activity of TRAIL in prostate cancer xenografts through activation of FOXO transcription factor. PLoS ONE 2010, 5, e15627. [CrossRef] [PubMed]

283. Innocenti, A.; Gülçin, I.; Scozzafava, A.; Supuran, C.T. Carbonic anhydrase inhibitors. Antioxidant polyphenols effectively inhibit mammalian isoforms I-XV. Bioorganic Med. Chem. Lett. 2010, 20, 5050-5053. [CrossRef] [PubMed]

284. Hong, Y.B.; Kang, H.J.; Kim, H.J.; Rosen, E.M.; Dakshanamurthy, S.; Rondanin, R.; Baruchello, R.; Grisolia, G.; Daniele, S.; Bae, I. Inhibition of cell proliferation by a resveratrol analog in human pancreatic and breast cancer cells. Exp. Mol. Med. 2009, 41, 151. [CrossRef] [PubMed]

285. Podhorecka, M.; Halicka, D.; Klimek, P.; Kowal, M.; Chocholska, S.; Dmoszynska, A. Resveratrol increases rate of apoptosis caused by purine analogues in malignant lymphocytes of chronic lymphocytic leukemia. Ann. Hematol. 2011, 90, 173-183. [CrossRef] [PubMed]

286. Archivio, M.; Filesi, C.; Di Benedetto, R.; Gargiulo, R.; Giovannini, C.; Masella, R. Polyphenols, dietary sources and bioavailability. Ann. -Ist. Super. Di Sanita 2007, 43, 348.

287. He, S.; Yan, X. From resveratrol to its derivatives: new sources of natural antioxidant. Curr. Med. Chem. 2013, 20, 1005-1017.

288. She, Q.-B.; Bode, A.M.; Ma, W.-Y.; Chen, N.-Y.; Dong, Z. Resveratrol-induced activation of p53 and apoptosis is mediated by extracellular-signal-regulated protein kinases and p38 kinase. Cancer Res. 2001, 61, 1604-1610.

289. Yang, P.-M.; Chou, C.-J.; Tseng, S.-H.; Hung, C.-F. Bioinformatics and in vitro experimental analyses identify the selective therapeutic potential of interferon gamma and apigenin against cervical squamous cell carcinoma and adenocarcinoma. Oncotarget 2017, 8, 46145. [CrossRef]

290. Xu, Y.; Xin, Y.; Diao, Y.; Lu, C.; Fu, J.; Luo, L.; Yin, Z. Synergistic effects of apigenin and paclitaxel on apoptosis of cancer cells. PLoS ONE 2011, 6, e29169. [CrossRef]

291. Dasari, S.; Tchounwou, P.B. Cisplatin in cancer therapy: molecular mechanisms of action. Eur. J. Pharmacol. 2014, 740, 364-378. [CrossRef] [PubMed]

292. Erdogan, S.; Turkekul, K.; Serttas, R.; Erdogan, Z. The natural flavonoid apigenin sensitizes human CD44+ prostate cancer stem cells to cisplatin therapy. Biomed. Pharmacother. 2017, 88, 210-217. [CrossRef]

293. Ju, S.M.; Kang, J.G.; Bae, J.S.; Pae, H.O.; Lyu, Y.S.; Jeon, B.H. The flavonoid apigenin ameliorates cisplatin-induced nephrotoxicity through reduction of p53 activation and promotion of PI3K/Akt pathway in human renal proximal tubular epithelial cells. Evid. -Based Complementary Altern. Med. 2015, 2015, 186436. [CrossRef] [PubMed]

294. Mahbub, A.; Le Maitre, C.; Haywood-Small, S.; Cross, N.; Jordan-Mahy, N. Polyphenols act synergistically with doxorubicin and etoposide in leukaemia cell lines. Cell Death Discov. 2015, 1, 15043. [CrossRef]

295. Yang, L.; Allred, K.F.; Dykes, L.; Allred, C.D.; Awika, J.M. Enhanced action of apigenin and naringenin combination on estrogen receptor activation in non-malignant colonocytes: Implications on sorghum-derived phytoestrogens. Food Funct. 2015, 6, 749-755. [CrossRef] [PubMed]

296. Lee, S.H.; Ryu, J.K.; Lee, K.-Y.; Woo, S.M.; Park, J.K.; Yoo, J.W.; Kim, Y.-T.; Yoon, Y.B. Enhanced anti-tumor effect of combination therapy with gemcitabine and apigenin in pancreatic cancer. Cancer Lett. 2008, 259, 39-49. [CrossRef]

297. Narayanan, N.K.; Nargi, D.; Randolph, C.; Narayanan, B.A. Liposome encapsulation of curcumin and resveratrol in combination reduces prostate cancer incidence in PTEN knockout mice. Int. J. Cancer 2009, 125, 1-8. [CrossRef]

298. Xu, G.; Ren, G.; Xu, X.; Yuan, H.; Wang, Z.; Kang, L.; Yu, W.; Tian, K. Combination of curcumin and green tea catechins prevents dimethylhydrazine-induced colon carcinogenesis. Food Chem. Toxicol. 2010, 48, 390-395. [CrossRef]

299. Zheng, J.; Zhou, Y.; Li, Y.; Xu, D.-P.; Li, S.; Li, H.-B. Spices for prevention and treatment of cancers. Nutrients 2016, 8, 495. [CrossRef]

300. Kakarala, M.; Brenner, D.E.; Korkaya, H.; Cheng, C.; Tazi, K.; Ginestier, C.; Liu, S.; Dontu, G.; Wicha, M.S. Targeting breast stem cells with the cancer preventive compounds curcumin and piperine. Breast Cancer Res. Treat. 2010, 122, 777-785. [CrossRef] [PubMed]

301. Kang, H.J.; Lee, S.H.; Price, J.E.; Kim, L.S. Curcumin Suppresses the Paclitaxel-Induced Nuclear Factor-kB in Breast Cancer Cells and Potentiates the Growth Inhibitory Effect of Paclitaxel in a Breast Cancer Nude Mice Model. Breast J. 2009, 15, 223-229. [CrossRef] [PubMed] 
302. Awale, S.; Lu, J.; Kalauni, S.K.; Kurashima, Y.; Tezuka, Y.; Kadota, S.; Esumi, H. Identification of arctigenin as an antitumor agent having the ability to eliminate the tolerance of cancer cells to nutrient starvation. Cancer Res. 2006, 66, 1751-1757. [CrossRef] [PubMed]

303. Wang, P.; Wang, B.; Chung, S.; Wu, Y.; Henning, S.M.; Vadgama, J.V. Increased chemopreventive effect by combining arctigenin, green tea polyphenol and curcumin in prostate and breast cancer cells. Rsc Adv. 2014, 4, 35242-35250. [CrossRef] [PubMed]

304. Zhou, D.-H.; Wang, X.; Yang, M.; Shi, X.; Huang, W.; Feng, Q. Combination of low concentration of (-)-epigallocatechin gallate (EGCG) and curcumin strongly suppresses the growth of non-small cell lung cancer in vitro and in vivo through causing cell cycle arrest. Int. J. Mol. Sci. 2013, 14, 12023-12036. [CrossRef]

305. Eom, D.-W.; Lee, J.H.; Kim, Y.-J.; Hwang, G.S.; Kim, S.-N.; Kwak, J.H.; Cheon, G.J.; Kim, K.H.; Jang, H.-J.; Ham, J. Synergistic effect of curcumin on epigallocatechin gallate-induced anticancer action in PC3 prostate cancer cells. Bmb Rep. 2015, 48, 461. [CrossRef] [PubMed]

306. Nautiyal, J.; Banerjee, S.; Kanwar, S.S.; Yu, Y.; Patel, B.B.; Sarkar, F.H.; Majumdar, A.P. Curcumin enhances dasatinib-induced inhibition of growth and transformation of colon cancer cells. Int. J. Cancer 2011, 128, 951-961. [CrossRef] [PubMed]

307. Andrzejewski, T.; Deeb, D.; Gao, X.; Danyluk, A.; Arbab, A.S.; Dulchavsky, S.A.; Gautam, S.C. Therapeutic efficacy of curcumin/TRAIL combination regimen for hormone-refractory prostate cancer. Oncol. Res. Featur. Preclin. Clin. Cancer Ther. 2008, 17, 257-267. [CrossRef]

308. Shankar, S.; Ganapathy, S.; Chen, Q.; Srivastava, R.K. Curcumin sensitizes TRAIL-resistant xenografts: molecular mechanisms of apoptosis, metastasis and angiogenesis. Mol. Cancer 2008, 7, 16. [CrossRef]

309. Yoshida, K.; Toden, S.; Ravindranathan, P.; Han, H.; Goel, A. Curcumin sensitizes pancreatic cancer cells to gemcitabine by attenuating PRC2 subunit EZH2, and the lncRNA PVT1 expression. Carcinogenesis 2017, 38, 1036-1046. [CrossRef]

310. Aichinger, G.; Beisl, J.; Marko, D. Genistein and delphinidin antagonize the genotoxic effects of the mycotoxin alternariol in human colon carcinoma cells. Mol. Nutr. Food Res. 2017, 61, 1600462. [CrossRef] [PubMed]

311. Aichinger, G.; Pahlke, G.; Nagel, L.; Berger, W.; Marko, D. Bilberry extract, its major polyphenolic compounds, and the soy isoflavone genistein antagonize the cytostatic drug erlotinib in human epithelial cells. Food Funct. 2016, 7, 3628-3636. [CrossRef] [PubMed]

312. Paul, B.; Li, Y.; Tollefsbol, T. The effects of combinatorial genistein and sulforaphane in breast tumor inhibition: Role in epigenetic regulation. Int. J. Mol. Sci. 2018, 19, 1754. [CrossRef] [PubMed]

313. Pons, D.G.; Nadal-Serrano, M.; Torrens-Mas, M.; Oliver, J.; Roca, P. The phytoestrogen genistein affects breast cancer cells treatment depending on the ER $\alpha / \mathrm{ER} \beta$ ratio. J. Cell. Biochem. 2016, 117, 218-229. [CrossRef] [PubMed]

314. Harper, C.E.; Cook, L.M.; Patel, B.B.; Wang, J.; Eltoum, I.A.; Arabshahi, A.; Shirai, T.; Lamartiniere, C.A. Genistein and resveratrol, alone and in combination, suppress prostate cancer in SV-40 tag rats. Prostate 2009, 69, 1668-1682. [CrossRef] [PubMed]

315. Kumar, R.; Verma, V.; Jain, A.; Jain, R.K.; Maikhuri, J.P.; Gupta, G. Synergistic chemoprotective mechanisms of dietary phytoestrogens in a select combination against prostate cancer. J. Nutr. Biochem. 2011, 22, 723-731. [CrossRef] [PubMed]

316. Hsieh, T.-C.; Wu, J.M. Targeting CWR22Rv1 prostate cancer cell proliferation and gene expression by combinations of the phytochemicals EGCG, genistein and quercetin. Anticancer Res. 2009, 29, 4025-4032.

317. Alobaedi, O.H.; Talib, W.H.; Basheti, I.A. Antitumor effect of thymoquinone combined with resveratrol on mice transplanted with breast cancer. Asian Pac. J. Trop. Med. 2017, 10, 400-408. [CrossRef]

318. Singh, C.K.; Ahmad, N. Resveratrol-Quercetin combination significantly inhibits prostate cancer in TRAMP mice. Am. Asso. Cancer Res. 2015, 75, 2801.

319. Al Fatease, A.; Shah, V.; Nguyen, D.X.; Cote, B.; LeBlanc, N.; Rao, D.A.; Alani, A.W. Chemosensitization and mitigation of Adriamycin-induced cardiotoxicity using combinational polymeric micelles for co-delivery of quercetin/resveratrol and resveratrol/curcumin in ovarian cancer. Nanomed. Nanotechnol. Biol. Med. 2019, 19, 39-48. [CrossRef]

320. Xu, J.; Liu, D.; Niu, H.; Zhu, G.; Xu, Y.; Ye, D.; Li, J.; Zhang, Q. Resveratrol reverses Doxorubicin resistance by inhibiting epithelial-mesenchymal transition (EMT) through modulating PTEN/Akt signaling pathway in gastric cancer. J. Exp. Clin. Cancer Res. 2017, 36, 19. [CrossRef] [PubMed] 
321. Ślusarz, A.; Shenouda, N.S.; Sakla, M.S.; Drenkhahn, S.K.; Narula, A.S.; MacDonald, R.S.; Besch-Williford, C.L.; Lubahn, D.B. Common botanical compounds inhibit the hedgehog signaling pathway in prostate cancer. Cancer Res. 2010, 70, 3382-3390. [CrossRef] [PubMed]

322. Castillo-Pichardo, L.; Dharmawardhane, S.F. Grape polyphenols inhibit Akt/mammalian target of rapamycin signaling and potentiate the effects of gefitinib in breast cancer. Nutr. Cancer 2012, 64, 1058-1069. [CrossRef] [PubMed]

323. Ávila-Gálvez, M.Á.; García-Villalba, R.; Martínez-Díaz, F.; Ocaña-Castillo, B.; Monedero-Saiz, T.; Torrecillas-Sánchez, A.; Abellán, B.; González-Sarrías, A.; Espín, J.C. Metabolic profiling of dietary polyphenols and methylxanthines in normal and malignant mammary tissues from breast cancer patients. Mol. Nutr. Food Res. 2019, 63, 1801239. [CrossRef] [PubMed]

324. Zhou, Y.; Tang, J.; Du, Y.; Ding, J.; Liu, J.-Y. The green tea polyphenol EGCG potentiates the antiproliferative activity of sunitinib in human cancer cells. Tumor Biol. 2016, 37, 8555-8566. [CrossRef]

325. Papi, A.; Farabegoli, F.; Iori, R.; Orlandi, M.; De Nicola, G.R.; Bagatta, M.; Angelino, D.; Gennari, L.; Ninfali, P. Vitexin-2-O-xyloside, raphasatin and (-)-epigallocatechin-3-gallate synergistically affect cell growth and apoptosis of colon cancer cells. Food Chem. 2013, 138, 1521-1530. [CrossRef]

326. Lambert, J.D.; Sang, S.; Yang, C.S. N-Acetylcysteine enhances the lung cancer inhibitory effect of epigallocatechin-3-gallate and forms a new adduct. Free Radic. Biol. Med. 2008, 44, 1069-1074. [CrossRef]

327. Kostin, S.F.; McDonald, D.E.; McFadden, D.W. Inhibitory effects of (-)-epigallocatechin-3-gallate and pterostilbene on pancreatic cancer growth in vitro. J. Off Surg. Res. 2012, 177, 255-262. [CrossRef]

328. Basu, A.; Haldar, S. Combinatorial effect of epigallocatechin-3-gallate and TRAIL on pancreatic cancer cell death. Int. J. Oncol. 2009, 34, 281-286. [CrossRef]

329. Toden, S.; Tran, H.-M.; Tovar-Camargo, O.A.; Okugawa, Y.; Goel, A. Epigallocatechin-3-gallate targets cancer stem-like cells and enhances 5-fluorouracil chemosensitivity in colorectal cancer. Oncotarget 2016, 7, 16158. [CrossRef]

330. Sinha, S.; Shukla, S.; Khan, S.; Tollefsbol, T.O.; Meeran, S.M. Epigenetic reactivation of p21CIP1/WAF1 and KLOTHO by a combination of bioactive dietary supplements is partially ER $\alpha$-dependent in ER $\alpha$-negative human breast cancer cells. Mol. Cell. Endocrinol. 2015, 406, 102-114. [CrossRef] [PubMed]

331. Royston, K.; Udayakumar, N.; Lewis, K.; Tollefsbol, T. A novel combination of withaferin A and sulforaphane inhibits epigenetic machinery, cellular viability and induces apoptosis of breast cancer cells. Int. J. Mol. Sci. 2017, 18, 1092. [CrossRef] [PubMed]

332. Fuentes, F.; Gomez, Y.; Paredes-Gonzalez, X.; Barve, A.; Nair, S.; Yu, S.; Saw, C.L.L.; Kong, A.-N.T. Nrf2-mediated antioxidant and detoxifying enzyme induction by a combination of curcumin and sulforaphane. Gene Expr. 2016, 11, 18.

333. Chen, H.; Landen, C.N.; Li, Y.; Alvarez, R.D.; Tollefsbol, T.O. Epigallocatechin gallate and sulforaphane combination treatment induce apoptosis in paclitaxel-resistant ovarian cancer cells through hTERT and Bcl-2 down-regulation. Exp. Cell Res. 2013, 319, 697-706. [CrossRef] [PubMed]

334. Nair, S.; Barve, A.; Khor, T.-O.; Shen, G.-X.; Lin, W.; Chan, J.Y.; Cai, L.; Kong, A.-N. Regulation of Nrf2-and AP-1-mediated gene expression by epigallocatechin-3-gallate and sulforaphane in prostate of Nrf2-knockout or C57BL/6J mice and PC-3 AP-1 human prostate cancer cells. Acta Pharmacol. Sin. 2010, 31, 1223. [CrossRef] [PubMed]

335. Nair, S.; Hebbar, V.; Shen, G.; Gopalakrishnan, A.; Khor, T.O.; Yu, S.; Xu, C.; Kong, A.-N. Synergistic effects of a combination of dietary factors sulforaphane and (-) epigallocatechin-3-gallate in HT-29 AP-1 human colon carcinoma cells. Pharm. Res. 2008, 25, 387-399. [CrossRef]

336. Islam, S.; Mokhtari, R.; Akbari, P.; Hatina, J.; Yeger, H.; Farhat, W. Simultaneous targeting of bladder tumor growth, survival, and epithelial-to-mesenchymal transition with a novel therapeutic combination of acetazolamide (AZ) and sulforaphane (SFN). Target. Oncol. 2016, 11, 209-227. [CrossRef]

337. Burnett, J.P.; Lim, G.; Li, Y.; Shah, R.B.; Lim, R.; Paholak, H.J.; McDermott, S.P.; Sun, L.; Tsume, Y.; Bai, S. Sulforaphane enhances the anticancer activity of taxanes against triple negative breast cancer by killing cancer stem cells. Cancer Lett. 2017, 394, 52-64. [CrossRef]

(C) 2019 by the authors. Licensee MDPI, Basel, Switzerland. This article is an open access article distributed under the terms and conditions of the Creative Commons Attribution (CC BY) license (http://creativecommons.org/licenses/by/4.0/). 